\title{
Normapolles Pollen from the Mississippi Embayment
}

\section{GEOLOGICAL SURVEY PROFESSIONAL PAPER 865}

Work done in cooperation with the

Kentucky Geological Survey

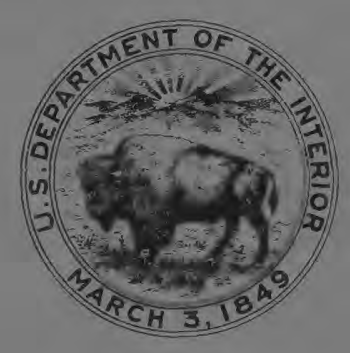




\section{Normapolles Pollen from the Mississippi Embayment}

By ROBERT H. TSCHUDY

GEOLOGICAL SURVEY PROFESSIONAL PAPER 865

Work done in cooperation with the Kentucky Geological Survey

Taxonomy and stratigraphic ranges of Normapolles genera and species found in Mississippi embayment rocks

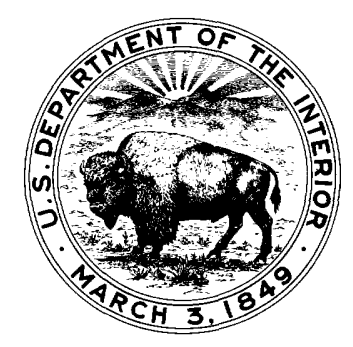




\section{UNITED STATES DEPARTMENT OF THE INTERIOR}

\section{GEOLOGICAL SURVEY}

V. E. McKelvey, Director

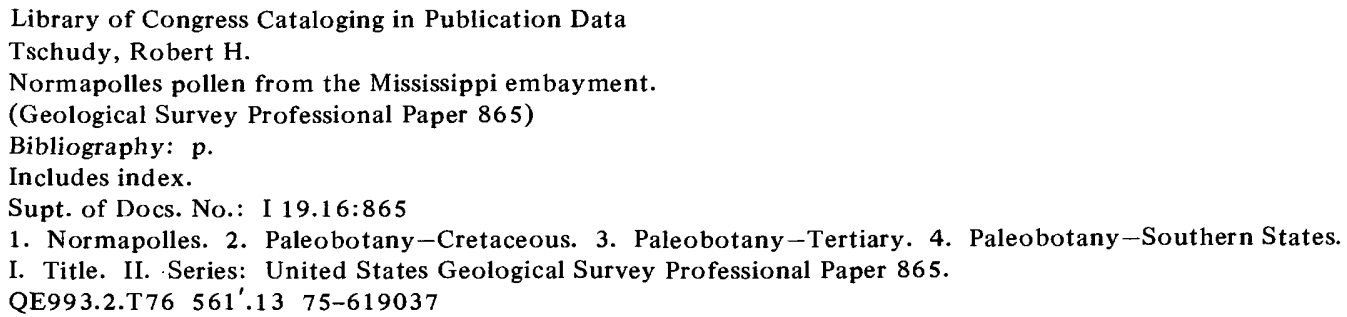

For sale by the Superintendent of Documents, U.S. Government Printing Office Washington, D.C. 20402 


\section{CONTENTS}

Page

Abstract _- - - - - - - - - - - - - - - - - - - Introduction _.....

Previous reports, North American _.

Taxonomic reports _

Nontaxonomic references _.

Acknowledgments

Methods

Fossil pollen sample localities

Type specimens _.

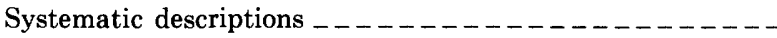

Genus Basopollis _- $\ldots \ldots \ldots-\ldots$

Basopollis obscurocostatus, n. sp _-

Genus Choanopollenites

cf. Choanopollenites sp

Genus Complexiopollis _ - - -----------

Genus Extremipollis _.--

Extremipollis vivus, n. sp Extremipollis versatilis, n. sp _-

Extremipollis caminus, n. sp

Genus Interpollis _

Interpollis $\mathrm{cf}$. I. supplingensis

Interpollis microsupplingensis _............

Interpollis intranodus, $\mathrm{n}$. sp

Genus Interporopollenites _Interporopollenites turgidus, $\mathbf{n}$. sp

Genus Kyandopollenites _._Kyandopollenites anneratus _...

Genus Megatriopollis _._. Megatriopollis? sp _-_

Genus Minorpollis _Minorpollis minimus _........ Minorpollis aff. $M$. minimus

Genus Nudopollis _._.

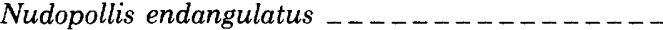
Nudopollis aff. $N$. endangulatus _- $\ldots \ldots \ldots$ Nudopollis terminalis _._. Nudopollis terminalis subsp. hastaformis _. Nudopollis terminalis subsp. hebeformis _. Nudopollis aff. N. terminalis _._. Nudopollis thiergartii _.................. Nudopollis thiergartii subsp. meridium _. Nudopollis thiergartii subsp. conspicuus _ Nudopollis thiergartii subsp. minutus _ _ _. _ _. Nudopollis aff. $N$. thiergartii

Genus Pecakipollis _------------- ---cf. Pecakipollis sp _-

Genus Plicapollis _Plicapollis usitatus, n. sp Plicapollis retusus, $\mathrm{n}$. $\mathrm{sp}$ Plicapollis vacuus, n. sp _
Systematic descriptions - Continued

Genus Plicapollis - Continued

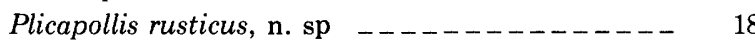

Genus Pompeckjoidaepollenites ___

Pompeckjoidaepollenites aff. P. subhercynicus _- 19

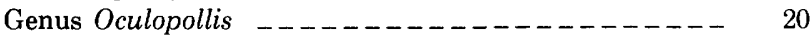

Genus Pseudoculopollis _-_-_.

Pseudoculopollis admirabilis, n. sp _-_-_.-- 20

Pseudoculopollis sp. A ________-

Genus Semioculopollis _-

Semioculopollis sp. A _

Genus Pseudoplicapollis _-

Pseudoplicapollis endocuspis, n. sp _-_-_---- 22

Pseudoplicapollis serenus, n. sp ________- 22

Pseudoplicapollis sp. A ____-

Genus Pseudovacuopollis _____-

Pseudovacuopollis involutus, n. sp

Genus Thomsonipollis _-_-_-

Thomsonipollis magnificus _._.

Thomsonipollis magnificoides ___-_-_-_-_- 24

Thomsonipollis aff. T. magnificoides _- - - - 24

Thomsonipollis expolitus, n. sp _-_-_-_- 25

Genus Trudopollis ___

Trudopollis variabilis, n. sp _-_-_-

Trudopollis plenus, n. sp _____-

Trudopollis cf. T. artifex

Trudopollis sp. A _-

Trudopollis sp. B

Trudopollis sp. C _._.

Genus Vacuopollis _-

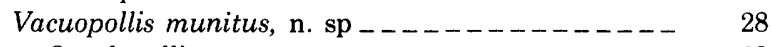

Genus Osculapollis, n. gen _-_-

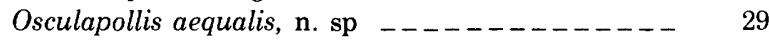

Osculapollis perspectus, n. sp _-

Osculapollis sp. A _-

Genus Praecursipollis, n. gen _- _-

Praecursipollis plebius, n. sp

Genus Pseudatlantopollis, n. gen ____-_-_-_-_ 30

Pseudatlantopollis simulatus, n. sp

Genus Endoinfundibulapollis, n. gen

Endoinfundibulapollis distinctus, n. sp _-_.

New genus A _- - - - -

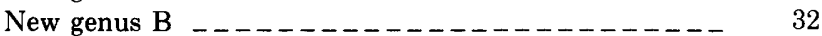

New genus C

New genus D

Key to Mississippi embayment Normapolles genera _- - 33

Stratigraphic distribution of Normapolles genera _ _ _ _ - 35

Stratigraphic distribution of Normapolles species _-

References -- - - - - - - - - - - - $-------\quad 39$

Index 


\section{ILLUSTRATIONS}

[Plates follow index]

Plate 1. Basopollis obscurocostatus and cf. Choanopollenites sp.

2. Extremipollis vivus and E. versatilis.

3. Extremipollis caminus.

4. Interpollis cf. I. supplingensis and I. microsupplingensis.

5. Interpollis intranodus.

6. Interporopollenites turgidus.

7. Kyandopollenites anneratus and Megatriopollis? sp.

8. Minorpollis aff. $M$. minimus, Nudopollis aff. $N$. endangulatus, $N$. aff. $N$. thiergartii, and $N$. aff. $N$. terminalis.

9. cf. Pecakipollis sp., Plicapollis usitatus, and P. retusus.

10. Plicapollis vacuus and $P$. rusticus.

11. Pompeckjoidaepollenites aff. P. subhercynicus and Pseudoculopollis admirabilis.

12. Pseudoculopollis sp. A. and Semioculopollis sp. A.

13. Pseudoplicapollis endocuspis, P. serenus, and P. sp. A.

14. Pseudovacuopollis involutus and Thomsonipollis magnificus.

15. Thomsonipollis magnificoides and T. aff. T. magnificoides.

16. Thomsonipollis expolitus and Trudopollis variabilis.

17. Trudopollis plenus, T. cf. T. artifex, and T. sp. A, B, and C.

18. Vacuopollis munitus, Osculapollis aequalis, O. perspectus, and $O$. sp. A.

19. Praecursipollis plebius and Pseudatlantopollis simulatus.

20. Endoinfundibulapollis distinctus and New Genera A, B, C, and D.

FiguREs 1-42. Sketches showing:

1. Basopollis obscurocostatus

2. Cf. Choanopollenites sp

3. Extremipollis vivus

4. Extremipollis versatilis _.

5. Extremipollis caminus

6. Interpollis cf. I. supplingensis

7. Interpollis intranodus _.

8. Interporopollenites turgidus

9. Kyandopollenites anneratus _.

10. Megatriopollis? sp. _- Minorpolis aff.

11. Minorpollis aff. M. minimus _

12. cf. Pecakipollis sp. -

13. Plicapollis usitatus _-

14. Plicapollis retusus _.

15. Plicapollis vacuus

16. Plicapollis rusticus _-

17. Pseudoculopollis admirabilis

18. Pseudoculopollis sp. A _

19. Semioculopollis sp. A _

20. Pseudoplicapollis endocuspis _.

21. Pseudoplicapollis serenus

22. Pseudoplicapollis sp. A _._.

23. Pseudovacuopollis involutus _._.

24. Thomsonipollis aff. T. magnificoides

25. Thomsonipollis expolitus _

26. Trudopollis variabilis _

27. Trudopollis plenus _._.

28. Trudopollis cf. T. artifex

29. Trudopollis sp. A.

30. Trudopollis sp. B.

31. Trudopollis sp. C. _._.

32. Vacuopollis munitus _._.

33. Osculapollis aequalis

34. Osculapollis perspectus _.

35. Osculapollis sp. A. -

36. Praecursipollis plebius _.

37. Pseudatlantopollis simulatus _.

38. Endoinfundibulapollis distinctus 
FIGURES 1-42. Sketches - Continued

39. New Genus A _

40. New Genus B

41. New Genus C _

42. New Genus D _ _

43. Chart showing comparison of stratigraphic distribution of Normapolles genera in Europe and Mississippi embayment _._.

44. Chart showing stratigraphic ranges of Normapolles species in Mississippi embayment 


\title{
NORMAPOLLES POLLEN FROM THE MISSISSIPPI EMBAYMENT
}

\author{
By ROBERT H. TSCHUDY
}

\begin{abstract}
The Normapolles group of fossil pollen genera is extinct. Pollen types of the included genera are triaperturate, morphologically complex, and distinctly different from types produced by extant pollen genera. Genera included in this somewhat heterogeneous group were first described from the Late Cretaceous and early Tertiary of Europe. In recent years increasing mention has been made of Normapolles genera observed in pollen preparations from North American rocks, and several new genera, not known from Europe, have been described. Taxonomic evaluations of North American Normapolles genera and species, however, have been minimal. This paper lists and evaluates the Normapolles genera and species found in rocks from the Mississippi embayment province.

At the present time, 57 Normapolles genera have been reported from Europe, 47 from boreal Middle Europe and 10 from western Hungary. Only four Normapolles genera are common to the two European regions. In Mississippi embayment rocks I have found pollen assignable to 18 of the European Normapolles genera, to 2 additional genera previously described from the United States, and to 4 new genera that I have proposed. I have found and illustrated specimens of four additional potentially new genera, but have not named them because of insufficient numbers of specimens for diagnosis.

The development of Normapolles genera in the Mississippi embayment began with their first appearance in the Cenomanian. They increased in numbers, reaching a peak in the Campanian - Maestrichtian interval, then declined in numbers during the early Tertiary and finally disappeared at the end of middle Eocene time. This development approximately parallels the generic occurrence of the Normapolles group in Europe.
\end{abstract}

Some of the genera common to Europe and the Mississippi embayment show remarkably similar stratigraphic ranges, but the ranges of others are distinctly different in the two regions. Several genera apparently appear earlier in Mississippi embayment rocks than in European rocks. This phenomenon is at odds with the commonly held hypothesis that Europe is the center of development and dispersion of the Normapolles group as a whole. If a migration route from Europe to North America allowed some Normapolles genera to move from Europe to North America, an alternate hypothesis would allow other Normapolles genera originating independently in North America to migrate to Europe and, thus, appear there later in the stratigraphic record.

A total of 59 species assignable to Normapolles genera have been recognized from the Mississippi embayment. Of this number, 43 have been found in sufficient numbers that specific names could be assigned. Thirty-three of these species are confined to North America. This fact suggests that the North American genera were relatively isolated from their European counterparts.

Normapolles species by themselves, or in combination with pollen assemblages, have proved to be excellent indicators of the several segments of the Late Cretaceous-early Tertiary part of the stratigraphic column. The known range zone of each Normapolles species discussed is presented in a stratigraphic chart.

\section{INTRODUCTION}

The term "Normapolles" was proposed by Pflug (1953) to embrace a group of pollen form genera that possessed morphological characteristics distinctly different from the morphological characteristics of most modern pollen types. Pollen grains assigned to genera of the Normapolles group are commonly triangular and shallow lens-shaped (short axial), with apertures at the angles, although a few are spherical or nearly so. The apertures are complex and morphologically highly differentiated, sometimes to a degree that they have been referred to as having a "bizarre" construction. The morphology of the apertures and the associated wall structure, although vastly different within the group, is sufficiently distinctive that none of the included genera can be conveniently included in the porate, colpate, or colporate morphotypes. Plants that produced pollen assigned to these genera are, so far as is known, extinct, and their relationships to modern genera, and indeed families, are still in the realm of conjecture. The Normapolles group is a group of convenience and neither genetic nor morphologic relationship among all included genera is implied.

Pollen genera assignable to the Normapolles group had their origin during the Cenomanian and became virtually extinct at the end of the Eocene. Their postulated center of origin and dispersal was in central Europe (Góczán and others, 1967, p. 435). In North America this group of genera is virtually limited to the Mississippi embayment and the eastern coast, although specimens assignable to Normapolles genera have been reported from rocks deposited to the west of the Late Cretaceous North American midcontinental epeiric sea. In North America also, pollen of Normapolles genera has been found only in rocks of Late Cretaceous and early Tertiary age.

Krutzsch (1959) enlarged the normapolles group by the addition of several new form genera from the European Cretaceous and early Tertiary. Góczán, Groot, Krutzsch, and Pacltová (1967), in the light of new knowledge of the fine morphology of these pollen grain types, in an excellent monographic work, reevaluated all the then-known Normapolles genera, erected several new genera and included more complete and accurate 
diagnoses and diagrams, thus contributing to the clarification of many morphological details that serve to characterize the several genera. It is this European work by Góczán and his coworkers that provides the basis for an evaluation and listing of Normapolles genera and species from the Mississippi embayment area of the United States.

\section{PREVIOUS REPORTS, NORTH AMERICAN}

Previous reports of Normapolles genera from North America are largely confined to the eastern part of the United States; but four, the reports of Newman (1965), Drugg (1967), B. D. Tschudy (1971), and Chmura (1973), record Normapolles genera from the western part. Although new information has altered somewhat the circumscriptions of some genera, other genera are no longer valid, and some determinations were made on the basis of few specimens or poorly preserved material, the reader should note that the several authors at the times of publication assigned specimens to what they then consedered to be appropriate Normapolles genera and species.

These reports can be divided into two categories: (1) reports that include taxonomic diagnoses or descriptions, and (2) reports that mention Normapolles genera but do not provide descriptions or taxonomic details.

\section{TAXONOMIC REPORTS}

The first mention of a Normapolles genus from the United States appeared in a publication by Krutzsch (1960a). In that report Krutzsch established the genus Thomsonipollis, basing his diagnosis upon specimens from the early Eocene of Europe and from lower Eocene rocks near Austin, Tex. Two other reports proposed new Normapolles genera from the United States. Stover (in Stover and others, 1966) erected the new monotypic genera Choanopollenites and Kyandopollenites from specimens found in the early Eocene of Texas. These genera, though not formally included in the Normapolles group, undoubtedly belong there because of their complex morphological characteristics. B. D. Tschudy (1971) found and described two new Normapolles genera from upper Campanian rocks of Montana. These new genera are Siberiapollis and Montanapollis.

The first North American descriptions of species belonging to heretofore strictly European Normapolles genera are found in a publication by Groot, Penny, and Groot (1961). They described one species each of Turonipollis (now Complexiopollis), Sporopollis (now Pseudoplicapollis), Latipollis (now Complexiopollis), Quedlinburgipollis and Trudopollis, two species of Vacuopollis and three species of Plicapollis from Upper Cretaceous rocks of the Eastern United States, thus firmly establishing the presence of Normapolles genera other than Thomsonipollis on the North American continent. Groot and Groot (1962) mentioned or described one species each of the genera Latipollis (now Complexiopollis), Plicapollis, and Extratriporopollenites from the Brightseat Formation (Paleocene) of Maryland; and Fredericksen (1973) described a species of Plicapollis from the Tertiary of Mississippi. From the Cretaceous of Colorado, Newman (1965) described one species each of Conclavipollis (now Vacuopollis) and Trudopollis and mentioned a species of Sporopollis (now Pseudoplicapollis). Chmura (1973) described one species of Trudopollis and mentioned one species of Plicapollis from the Cretaceous of California. The reports by Newman and Chmura are the only ones describing European Normapolles genera and species from pollen specimens obtained from Western United States. Two reports on Late Cretaceous palynomorphs from Delaware and New Jersey appeared in 1966. Gray and Groot (1966) provided descriptions of two species of Plicapollis and two species of Trudopollis, and Kimyai (1966) described a single species of Conclavipollis (now Vacuopollis). Elsik (1968), in discussing the palynomorph flora of the Paleocene of Texas, emended the genus Thomsonipollis and listed one species each of Trudopollis, Plicapollis, Extratriporopollenites, Choanopollenites and two species of Nudopollis. More recently, R. H. Tschudy (1973b), in tracing the evolutionary development and stratigraphic distribution of the Complexiopollis lineage, described four new species of Complexiopollis and five new species of Choanopollenites from Cretaceous and lower Tertiary rocks of the Mississippi embayment region.

\section{NONTAXONOMIC REFERENCES}

Mention of the Genera Extratriporopollenites and Trudopollis in Paleocene and lower Eocene rocks of Arkansas was made by Jones (1962), and in the same year Brown and Pierce (1962) figured specimens from the Turonian of Texas that probably belong to genera of the Normapolles group under the name of Punctatricolporites. Leopold and Pakiser (1964) listed the genera Basopollis, Sporopollis (now Pseudoplicapollis), Complexiopollis, Latipollis (now Complexiopollis), Nudopollis, Minorpollis and Conclavipollis (now Vacuopollis) from the Late Cretaceous of western Alabama. Engelhardt (1964) listed and illustrated two species of the genus Extratriporopollenites from the Eocene Cockfield Formation of Mississippi. Drugg (1967) mentioned single species of the genera Nudopollis and Vacuopollis from the Late Cretaceous-early Tertiary transition of California. Doyle (1969) and Wolfe and Pakiser (1971) examined Upper Cretaceous rocks from the Atlantic Coastal Plain area and both recorded the genera Atlantopollis, Complexiopollis, Praebasopollis, Pecakipollis, Trudopollis, Plicapollis and Pseudoplicapollis. Doyle recorded Vacuopollis in addition, and Wolfe and Pakiser recorded in addition Semioculopollis, Heidelbergipollis, Minorpollis, Primipollis, Neotriangulipollis, and 14 new unnamed 
genera. They made no attempt to record the morphological characteristics of any of these genera. Fairchild and Elsik (1969), in discussing the characteristic palynomorphs of the Gulf lower Tertiary, listed two species of Nudopollis and one species each of Thomsonipollis and Choanopollenites. R. H. Tschudy (1973a) recorded one species of Kyandopollenites, two species of Nudopollis, and the genus Thomsonipollis from the Eocene of the Mississippi embayment. Góczán, Groot, Krutzsch, Pacltová (1967, p. 511) reported that types similar to Thomsonipollis magnificoides are known from "the Laramie of Raton Pass, Alabama/U.S.A." (Undoubtedly the Upper Cretaceous Laramie Formation from Raton Pass, Colo.).

\section{ACKNOWLEDGMENTS}

I thank Sharon Van Loenen and Kathryn Dieterich for their assistance in the preparation of the samples and Kathryn Dieterich for photography of the specimens.

\section{METHODS}

The methods employed for processing samples and preparing slides are standard for this laboratory and have been reported previously (Tschudy, R. H., 1970). A minor modification in procedures is the employment of the synthetic resin "Histoclad" as a mounting medium for some of the slides, replacing the previously used medium "Permount."

\section{FOSSIL POLLEN SAMPLE LOCALITIES}

The samples from Cretaceous and Tertiary rocks used in this study are from the numbered USGS Paleobotany localities listed below. The locations and detailed descriptions of the Cretaceous and Paleocene localities have been presented previously (Tschudy, R. H., 1973b). The localities and detailed information from Eocene samples have also been given in a previous publication (Tschudy, R. H., 1973a). This information is repeated here because of the desirability of having accurate incality data available in the same publication that proposes new taxa.

\begin{tabular}{|c|c|c|}
\hline $\begin{array}{c}\text { ISt:S } \\
\text { Paleobot inv } \\
\text { loc. }\end{array}$ & Locality & $\begin{array}{l}\text { Stratigraphic } \\
\text { unıt }\end{array}$ \\
\hline D3415 _ - - & 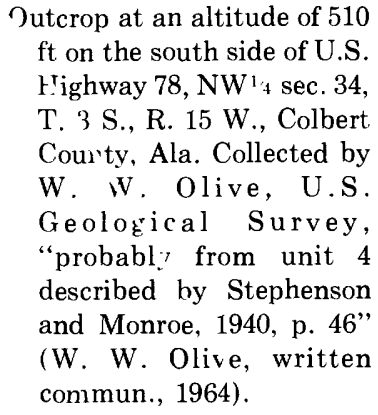 & $\begin{array}{l}\text { Tuscaloosa Formation, } \\
\text { Cenomanian. }\end{array}$ \\
\hline D3265 - - - & $\begin{array}{l}\text { E. W. Berry field designation } \\
6474 \text {. Collected at Broken }\end{array}$ & $\begin{array}{l}\text { Eutaw Formation, } \\
\text { Coniacian. }\end{array}$ \\
\hline
\end{tabular}

\begin{tabular}{cc}
\hline ISGS & Stratigraphic \\
Paleobotany & Locality
\end{tabular}

Arrow Bend of the Chattahoochee River about 13 miles below Columbus, Chattahoochee County, Ga. Matrix material from leaf locality collected by $\mathbf{E}$. W. Berry, U.S. Geological Survey, 1909. Matrix submitted by Jack Wolfe, U.S. Geological Survey, 1963.

D3260 _ _ _ E. W. Berry field designation 6471. Collected at the junction of Cowickee Creek and Chattahoochee River, Barbour County, Ala. Matrix material from leaf locality collected by $\mathrm{E}$. W. Berry, U.S. Geological Survey, 1909. Matrix submitted by Jack Wolfe, U.S. Geological Survey, 1963.

D3412 _ _ - Type locality, near middle. Elevation $440 \mathrm{ft}$ along bluff on left bank Tennessee River 0.3 mile downstream from river mile 185 and 0.9 mile east of crossroads north of Coffee Landing, Hardin County, Tenn. Collected by W. W. Olive, U.S. Geological Survey, 1964.

D3413 _ _ _ From roadcut along east side Tennessee Route 22, 0.8 mile north of intersection with Tennessee Route 100, Henderson County, Tenn. Collected by W. W. Olive, U.S. Geological Survey, 1964.

D1967 _ _ - Type locality of McNairy Sand Member. West end of big cut in Southern RR. east of Dismal Swamp and Tuscumbia River. Base is approximately same eleva. tion as track and is $40 \mathrm{ft}$ northwest of railroad crossing. South center $\mathrm{NW}^{1 / 4} \mathrm{SW}^{1 / 4}$, Chewala quadrangle, McNairy County, Tenn.

D1967-A_ - 0-14 in. above bottom of sequence.

B _ 14-26 in. above bottom of sequence.

C_ _ 26-38 in. above bottom of sequence.

Collected by E. M. Cushing, U.S. Geological Survey, 1962.
Cusseta Sand Member, Ripley Formation, Campanian.

Coffee Sand, Campanian.

Coon Creek Tongue of Ripley Formation, Maestrichtian.

McNairy Sand Member of Ripley Formation Maestrichtian.
Do.
Do.
Do. 


\begin{tabular}{|c|c|c|}
\hline $\begin{array}{c}\text { Istis } \\
\text { Paleobetany } \\
\text { loc. }\end{array}$ & Locality & $\begin{array}{c}\text { Stratigraphic } \\
\text { unit }\end{array}$ \\
\hline
\end{tabular}

D3416 _ _ $6 \mathrm{ft}$ below unconformable contact with Owl Creek Formation; NW ${ }^{1 / 4} \mathrm{NW}^{1 / 4}$ sec. 10 , T. 27 N., R. 11 E., Advance $7 \frac{1 / 2-m i n u t e}{}$ quadrangle, Stoddard County, Mo. Collected by W. W. Olive, U.S. Geological Survey, 1964.

D3410 _ _ Type locality. From right bank of Owl Creek, 2.5 miles northeast of Ripley, Miss.; $\mathrm{E}^{1 / 2}$ sec. 7, T. $4 \mathrm{~S}$., R. 4 E., Tippah County, Miss. Collected by W. W. Olive, U.S. Geological Survey, 1964.

D1966 _ _ 1.5 miles south-southwest of Cotton Plant, Miss., southwest wall of tributary to Guyton Creek along country road. $\mathrm{S}^{1 / 2} \mathrm{NW}^{1 / 4}$ sec. 8, T. 6 S., R. 3 E., Tippah County, Miss.

D1966-A_ - $6 \mathrm{ft}$ above basal limestone. B _ $-9 \mathrm{ft}$ above basal limestone. $\mathrm{C}_{-}-14 \mathrm{ft}$ above basal limestone. D_ $-15 \mathrm{ft}$ above basal limestone. E_ $17 \mathrm{ft}$ above basal limestone. F_ 20-23 ft above basal limestone.

Collected by E. M. Cushing, U.S. Geological Survey, 1962.

D3548 _ _ A Auger hole J. 12, about 1 mile from southwest corner Joppa $7^{1 / 2-\text { minute quad- }}$ rangle; Kentucky coordinates, South zone: E. $1,094,590 \mathrm{ft}$; N. $308,200 \mathrm{ft}$, McCracken County, Ky. [Depths are from top of auger hole]

D3548-A_ _ Depth 93-98 ft.

B__ Depth 77-93 ft.

C_- Depth 62-77 ft

D_ _ Depth 52-62 ft.

Collected by W. W. Olive, U.S. Geological Survey, 1965.

D3285 _ _ Channel of McCullough Fork, $300 \mathrm{ft}$ N. KentuckyTennessee State line. Kentucky coordinates, South zone: E. $1,263,500 \mathrm{ft}$; N. $70,250 \mathrm{ft}$, Hazel quadrangle, Calloway County, Ky. Collected by W. W. Olive, U.S. Geological Survey, 1963.
Upper part of McNairy Sand, Maestrichtian.

Owl Creek Formation, Maestrichtian.

Clayton Formation, Paleocene.

Clayton Formation Paleocene.

Porters Creek Clay, Paleocene.

Do.
Do.

Do.

\begin{tabular}{cc}
\hline USGS & Stratigraphic \\
$\begin{array}{c}\text { Paleobotany } \\
\text { loc. }\end{array}$ & Locality
\end{tabular}

D1849-

D1850 _ _ NW NW $^{1 / 4} \mathrm{SW}^{1 / 4}$ sec. 6, T. $11 \mathrm{~N}$., R. 11 W., De Soto Parish, La. Sample provided by W. W. Fairchild, Standard Oil Company of Texas, 1962.

D3138 _ _ Upper half Naheola Formation from along Alabama Highway 17 in $\mathrm{SE}^{1 / 4} \mathrm{NW}^{1 / 4}$ sec. 3, T. 15 N., R. 2 W., Choctaw County, Ala Sample provided by $\mathrm{C}$. W. Copeland, Geological Survey of Alabama, 1963.

D3268 _ _ . Type locality. From Coal Bluff on Alabama River, sec. 7, T. 11 N., R. 7 E., Wilcox County, Ala. Sample provided by $H$. T. Ames, Pennsylvania State Univ., 1963.

D3222 _ _ 0.2 mile east of bridge across Tucabum River on Lavaca-Pennington road on south side of new roadcut, sec. 22, T. 14 N., R. 1 W., Choctaw County, Ala. (See MacNeil, geologic map, 1946.) Collected by W. W. Olive and R. H. Tschudy, U.S. Geological Survey, 1963.

D1854 _. _ About 1 mile northeast of Ackerman, Miss., in railroad cut, Illinois Central Railway, at Blantons Gap, secs. 28 and 21, T. 17 N., R. 11 E., Choctaw County, Miss. (See Vestal, 1943, p. 30.) Collected by W. W. Olive, U.S. Geological Survey, 1962.

D1862 _ _ _ From south wall of the valley of Potts Creek, about 75 yards east of road bridge, $\mathrm{NW}^{1 / 4}$ sec. 4 , T. 6 S., R. 1 W., Marshall County, Miss. (See Vestal, 1954, p. 41.) Collected by W. W. Olive, U.S. Geological Survey, 1962.

D1846 _ _ Sample F48, NW ${ }^{1 / 4} \mathrm{SE}^{1 / 4}$ sec. 12, T. 6 N. R. 13 W., Sabine Parish, La., elev $165 \mathrm{ft}$. (See Andersen, 1960 , p. 74, 75, fig. 13.) Supplied through the courtesy of W. W. Fairchild, Standard Oil Co. of Texas, 1962.
Naborton Formation, Paleocene.

Naheola Formation, Paleocene.

Coal Bluff Marl Member of Naheola Formation, Paleocene

Nanafalia Formation. Wilcox Group, lower Eocene.

Wilcox Formation (formerly Ackerman Formation, type locality), lower Eocene.

Wilcox Formation (formerly Ackerman Formation), lower Eocene.

Bayou Lenann Member of Pendleton Formation (type locality) (Andersen, 1960). In Wilcox Group, lower Eocene. 


\begin{tabular}{ccc}
\hline $\begin{array}{c}\text { UISGS } \\
\begin{array}{c}\text { Paleobotany } \\
\text { loc. }\end{array}\end{array}$ & $\begin{array}{c}\text { Stratigraphic } \\
\text { unit }\end{array}$ \\
\hline
\end{tabular}

D1851 _ _ Sample F-129 from north side of Louisiana Highway 6, sec. 6, T. 6 N., R. 11 W., Sabine Parish, La. Ostrea multilirata zone. (See Andersen, 1960, p. 76.) Supplied through the courtesy of W. W. Fairchild, Standard Oil Co. of Texas, 1962.

D1855 _ - - North side of roadcut 1.5 miles west of corporate limit of Meridian, Miss., on U.S. Highway 80 , secs. 15, 22, T. 6 N., R. 15 E., Lauderdale County, Miss. (See Foster, 1940, p. 67.) Collected by W. W. Olive, U.S. Geological Survey, 1962.

D1848 _ _ - Sample F-71, from bed of Two Mile Creek, 1.5 miles due south of U.S. Highway 79 bridge across Brazos River, Milam County, Tex. (Stop 2 of Houston Geol. Soc. Ann. Field Trip, 1959. See Smith, 1959.) Supplied through the courtesy of W. W. Fairchild, Standard Oil Co. of Texas, 1962.

D1858 _ _ _ Holly Springs Brick and Tile Co., Holly Springs, Miss., pit south of Mississippi Highway 78, Poorhouse or No. 2 pit, $\mathrm{SE}^{1 / 4}$ sec. $26, \mathrm{~T}$. 3 S., R. 3 W., Marshall County, Miss. (See Vestal, 1954, p. 67-90.) Collected by W. W. Olive, U.S. Geological Survey, 1962.

D1856 _ _ 2.9 miles east of west city limits of Hickory, Miss., on U.S. Highway $80, \mathrm{NE}^{1 / 4}$ sec. 32 , T. 6 N., R. 13 E., Newton County, Miss. (See Priddy, 1961, p. 37.) Collected by W. W. Olive, U.S. Geological Survey, 1962.

D1852 _ - Sample F-130 from northeast side of Louisiana Highway 476, $\mathrm{SE}^{1 / 4}$ sec. 10, T. 5 N., R. 12 W., south of Negreet, Sabine Parish, La. (See Andersen, 1960, p. 87 and pl. 13.) Supplied through the courtesy of W. W. Fairchild, Standard Oil Co. of Texas, 1962.
Pendleton Formation (Andersen, 1960). In Wilcox Group, lower Eocene.

Uppermost part, Hatchetigbee Formation. In Wilcox Group, lower Eocene.

Marquez Shale Member (of Stenzel, 1938) of Reklaw Formation. In Claiborne Group, middle Eocene.

Tallahatta Formation. In Claiborne Group, middle Eocene.

Zilpha Clay. In Claiborne Group, middle Eocene.

Sparta Sand. In Claiborne Group, middle Eocene.

\begin{tabular}{|c|c|c|}
\hline $\begin{array}{c}\text { IISGS } \\
\text { Paleobotany } \\
\text { loc. }\end{array}$ & Locality & $\begin{array}{c}\text { Stratigraphic } \\
\text { unit }\end{array}$ \\
\hline
\end{tabular}

$\mathrm{D} 3421$ _ $-\mathrm{NW}^{1 / 4} \mathrm{SW}^{1 / 4} \mathrm{SW}^{1 / 4}$ sec. $23, \mathrm{~T}$. 16 S., R. 14 W., near south end of Calion Lake, Union County, Ark. Collected by H. N. Halberg, U.S. Geological Survey, 1964.

D4524 _ _ _ Just above iror bridge over Techeva Creek, SE $1 / 4$ NE1/4 sec. 16, T. 13 N., R. 1 W., Yazoo County, Miss. (Yegua Member of Lisbon Formation as used by Mellen, 1940, p. 14 and fig. 1.) Collected by E. H. Boswell, U.S. Geological Survey, 1970.

D4525 _ - - NE $\mathrm{NE}^{1 / 4} \mathrm{SW}^{1 / 4} \mathrm{SW}^{1 / 4}$ sec. 11, T. 5 N., R. 11 E., Newton County, Miss. (stratigraphically about equivalent to D4526. E. H. Boswell, written commun., 1970). Collected by E. H. Boswell, U.S. Geological Survey, 1970.

D4526 _ _ $\mathrm{SE}^{1 / 4} \mathrm{SW}^{1 / 4}$ sec. 32 , T. 4 N., R. 13 E., $1 / 2$ mile southeast of Rose Hill, Jasper County, Miss. (See DeVries, 1963 , p. 22, fig. 6.) Collected by E. H. Boswell, U.S. Geological Survey, 1970.

D3224 _ - _ South bluff of Garland Creek, 2.6 miles east of steel bridge over Chickasawhay River, 2 miles from house at road fork straight east along log trail. $6 \mathrm{ft}$ from top of formation, NW $1 / 4$ sec. 28, T. 1 N., R. 16 E., Clarke County, Miss. (See Holden and others, 1948, p. 60.) Collected by W. W. Olive and R. H. Tschudy, U.S. Geological Survey, 1963.

D3228 _ _ NW ${ }^{1 / 4} \mathrm{NW}^{1 / 4}$ sec. 36, T. $6 \mathrm{~N}$. R. 1 E., Riverside Park Jackson, Hinds County, Miss. Lignitic clay with borings. Collected by W. W. Olive and R. H. Tschudy, U.S. Geological Survey, 1963.

D3227 _ - NW ${ }^{1 / 4} \mathrm{NW}^{1 / 4}$ sec. 36 , T. 6 N., R. 1 E., Riverside Park, Jackson, Hinds County, Miss., $1 \frac{1 / 2}{\mathrm{ft}}$ below coquina bed. (See Moore, 1965, p. 48.) Collected by W. W.
Cook Mountain Formation. In Claiborne Group, middle Eocene.

Cockfield Formation. In Claiborne Group, middle Eocene.

Middle part, Cockfield Formation. In Claiborne Group, middle Eocene.

Do.

Upper part, Cockfield Formation. In Claiborne Group, middle Eocene.

Do.

Moodys Branch Formation (reference section). In Jackson Group, upper Eocene. 


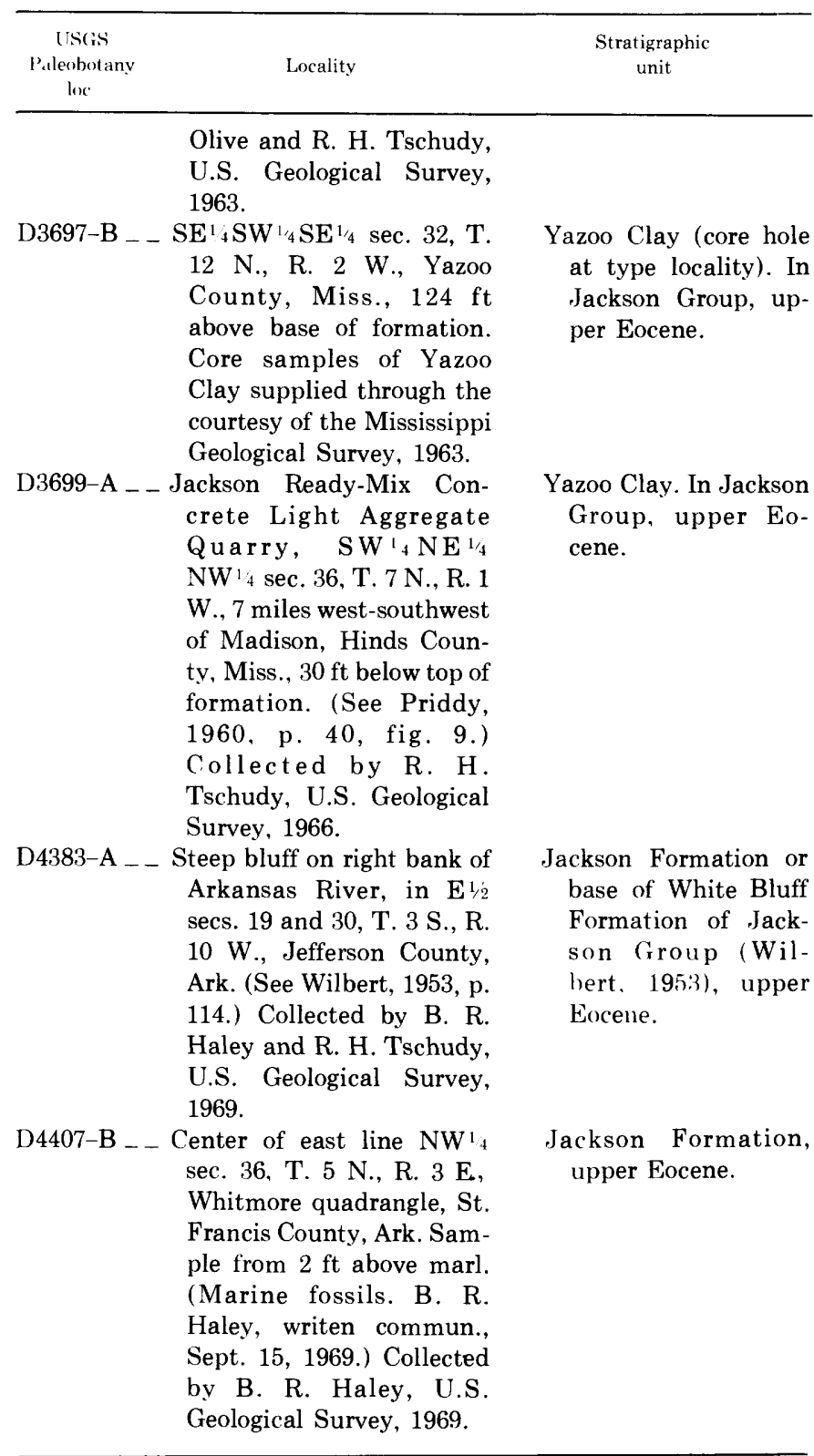

Four additional Late Cretaceous samples not included in previous publications were used in this study. These samples are not reference samples but are samples submitted for age determination by geologists working on the Kentucky cooperative mapping project. These samples were used because they yielded particularly good specimens of some of the taxa discussed.

\begin{tabular}{|c|c|c|}
\hline Sample & Locality & Formation \\
\hline D3002 & $\begin{array}{l}\text { Drill hole } 35 \text { (depth } 32-37 \mathrm{ft} \text { ) } \\
\text { immediately south of Ken- } \\
\text { tucky Highway } 444 \text { on east } \\
\text { side and adjacent to }\end{array}$ & $\begin{array}{c}\text { McNairy Sand Mem- } \\
\text { ber of Ripley Forma- } \\
\text { tion, Maestrichtian. }\end{array}$ \\
\hline
\end{tabular}

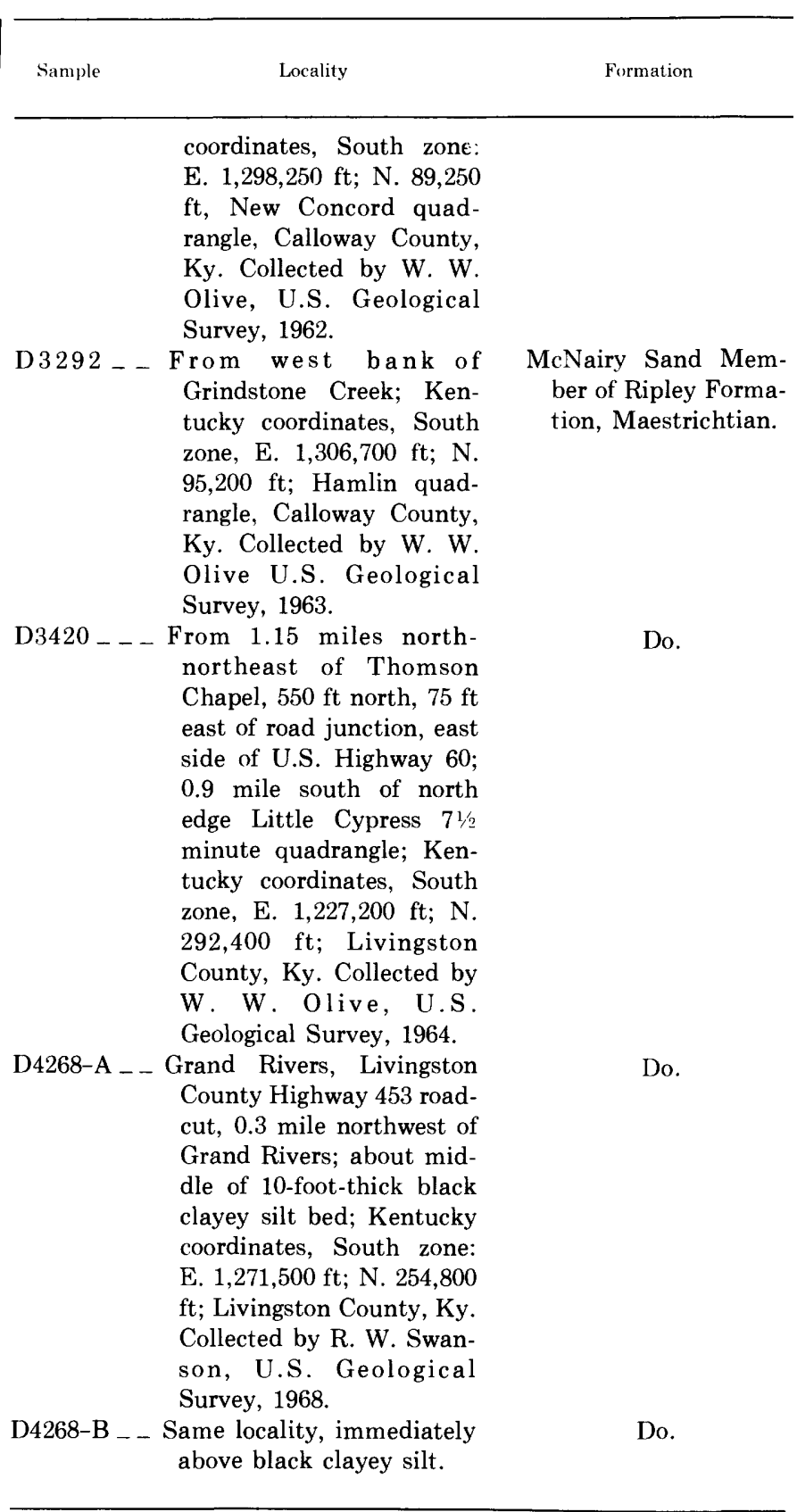

\section{TYPE SPECIMENS}

All specimens illustrated in this report are preserved on slides deposited in the paleobotanical collections of the U.S. Geological Survey, Denver, Colo. All illustrated specimens are within black-inked circles marked directly on the slides; they may also be located on the slides by the mechanical-stage coordinates given with the type designations and in the plate explanations. In order that others may convert their mechanical-stage readings to those recorded for the specimens included in this report, the coordinates for the center point of a 1$\times 3$-inch standard microscope slide are $108.0 \times 12.3 \mathrm{~mm}$. The method of accurately locating the center of a stan- 
dard microscope slide has been described by $\mathrm{R}$. H. Tschudy (1966, p. D78). With the slide label to the left, the vertical coordinates decrease toward the near edge of the slide, and the horizontal coordinates decrease toward the right edge of the slide.

Color transparencies of type and illustrated specimens described in this report are available from the U.S. Geological Survey laboratory, Denver, Colo., on a limited-time loan basis.

\section{SYSTEMATIC DESCRIPTIONS}

The genera belonging to the Normapolles group are discussed in alphabetical order. Newly proposed genera are presented at the end of the report. An arbitrary minimum of 10 good specimens was selected as a requirement before a name could be assigned to a new genus or new species. As a result of this decision several probable new taxa are mentioned but not named. As an aid to future workers, provisional descriptions are provided for these unnamed entities, but no formal diagnoses are made. For those genera and species already established, generic diagnoses are given. For many genera, these diagnoses are somewhat modified from the original German; a conscientious attempt has been made to retain the meaning expressed in the original versions. Direct word-for-word translation would have provided much more stilted diagnoses.

In several descriptions Góczán and others (1967) provided new wordings ("Neufassungen") for diagnoses of already established genera. These new wordings are not considered to be emendations by those authors, nor do I consider them to be emendations. For example, Góczán and others (1967), under the heading Basopollis Pflug, 1953b (p. 449), say "Wie aus der Diagnose zu ersehen ist, wurde sie unwesentlich verändert, sie ist vor allem weiter präzisiert worden. Dies ist heute möglich durch die Vielzahl neugefundener Formtypen. Die Bemerkungen zur Einheit in R. Potonié 1960, Syn. III (S. 126) sind uberholt und waren auch wenig zutreffend."

The complex morphology of pollen grains assigned to the Normapolles group of genera has prompted several European workers to institute new terminology for some of the more unusual morphological features of the grains. Many of these new terms, such as "interloculum" (space between the ektexine and endexine), are defined in the "Morphological Encyclopedia of Palynology" by Kremp (1965). All the terms used by Góczán and others (1967) in the new wordings of generic diagnoses are defined in section D of their publication.

Skarby (1968) raised some doubtless valid objections to the interpretations of the so-called diagnostic characters used by Pflug (1953) and by others for differentiating some of the Normapolles genera. Skarby (1968, p. 3) claimed that "Several of these diagnostic characters are derived from incorrect observations or misinterpretations of existing properties $* * *$." This claim is to some degree true. Unfortunately, Skarby was not familiar with the paper by Góczán and others (1967) in which the Normapolles genera are more accurately differentiated and morphological features present are more accurately described. This publication removes the bases for most of her objections. Skarby emended the genus Extratriporopollenites to include 23 Normapolles genera and the Postnormapolles genus Triatriopollenites. She did not recognize characters, such as "atrium," "interloculum," "solution-meridian," "oculus," and "endanulus" as diagnostically significant. Certain other generic characteristics such as "praevestibulum" (in Basopollis), she suggested may be optical phenomena or misinterpretation as the result of poor lenses or poor observation.

I have observed the morphological features described in Góczán and others (1967) for certain European Normapolles genera in specimens from the Mississippi embayment. As a result of the careful observations recorded by Góczán and others (1967), I have experienced little difficulty in differentiating Normapolles genera on the bases established by the above publication. I do not believe that the extreme "lumping" of genera resorted to by Skarby serves any useful purpose. Furthermore, the inclusion by Skarby (1968) of such morphologically diverse genera as Triatriopollenites, Complexiopollis (Latipollis, Turonipollis), Basopollis, and Plicapollis in the genus Extratriporopollenites is, I believe, totally unjustified.

\section{Genus BASOPOLLIS Pflug, 1953}

Type species. - Basopollis orthobasalis (Pf.) Pf.

Diagnosis. - ("New wording" from Góczán and others, 1967.) Pollen grains triangular, shallow lensshaped to extreme triplane; equatorial contour rigid triangular to extremely concave triangular; the three equatorial germinals at the angles are sometimes strongly distorted but generally do not contribute particularly to the equatorial contour, so that normally the equatorial contour is not strongly interrupted. Polar axes of very different lengths. Wall several layered, the outer part thicker than the closely lying inner part; surface smooth or mostly with strong punctate sculpture. Sometimes with plicae (principally in those with a tendency to a triplane shape). Exopores vertical slit shaped, more or less symmetrical to the equator, with two lamella complexes in the exogerminal: (1) A relatively thick sculpture bearing outer layer without internal structure, and (2) a typical polyannulate complex that is present from the root of the exogerminal; these complexes are sometimes clearly structured with radially directed bacula. Pore canal index among the several form species very different, mostly above 0.3 . Vestibulum present. Mesopore equatorial slit shaped with more or less gable-shaped protrusions of the upper 
and lower lips; lips are, however, generally without thickenings. "Endopore" is developed from the inner wall as a straight margined or weakly concave atrium. No oculi or polpapillae. Mostly medium sized, but sometimes large forms.

Remarks. - Distinguished from Complexiopollis principally by the typical polyannulate exogerminals.

\section{Basopollis obscurocostatus, n. sp.}

Plate 1, figures 1-12; text figure 1

Holotype. - Sample D1862, slide 3, prep. 2, coordinates $95.7 \times 3.9$. Wilcox Formation, Mississippi, lower Eocene.

Paratype. - Sample D1862, slide 3, prep. 2, coordinates $92.6 \times 16.1$. Wilcox Formation, Mississippi, lower Eocene.

Diagnosis. - Shape of pollen grains concave triangular in polar view, often distorted into the triplane form. Size $28 \mu-42 \mu$ in equatorial diameter (14 specimens). Wall of two principal layers, about $2 \mu$ thick

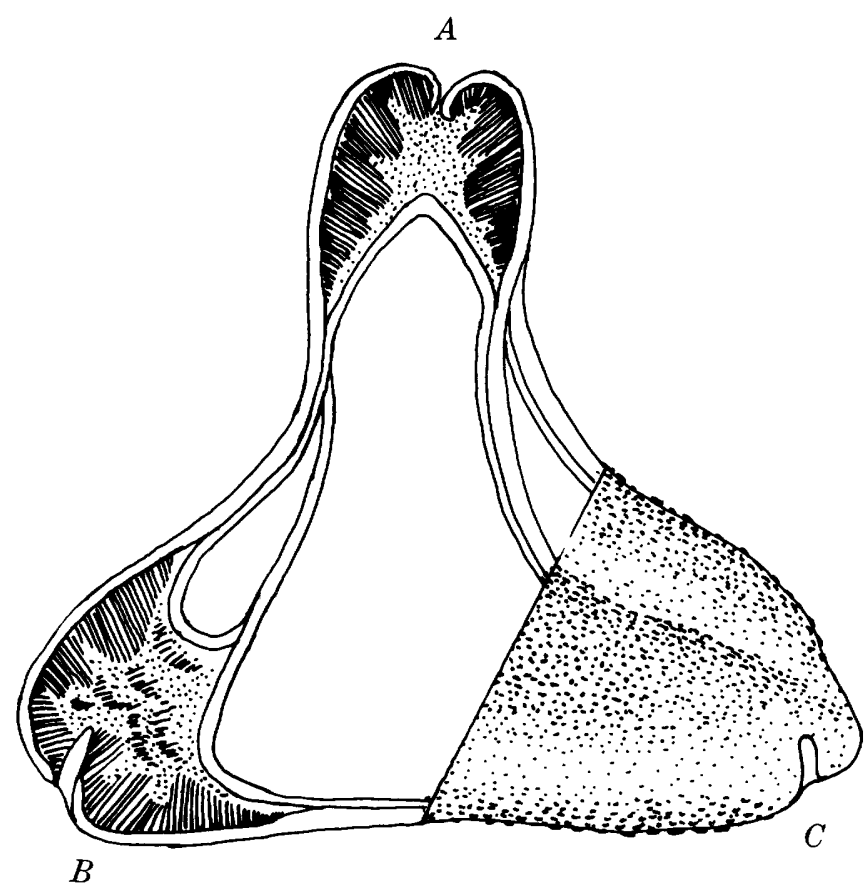

FIGURE 1. - Basopollis obscurocostatus, n. sp., ca. $\times 2,000 . A$, Aperture in polar view showing polyvestibulate characteristic of the exogerminal. $B$, Aperture in equatorial or partial triplane view showing arci and endexinal flaps. $C$, Surface view showing ornamentation.

in the interapertural areas. Presence of equatorial arci or ribs gives the impression of a thicker wall when grains are oriented in strict polar attitude; arci generally seen clearly only in triplane or equatorial view. Surface with scabrate to microverrucate sculpture. Ektexine about twice as thick as endexine. Apertural areas elongate. Exogerminals vertical slit shaped, bordered by characteristically polyannulate thickened ektexinal walls. Outer layer of germinal areas thin, structureless; inner layer of radially projecting bacula of uneven lengths forming thereby one or more praevestibulae. Vestibulum at base of exogerminal prominent but narrow. Endexine at position of endogerminal separated into two gable-shaped flaps separated by a large equatorially oriented slit. Delicate atrium below flaps not observed in specimens examined.

Remarks. - Basopollis obscurocostatus, n. sp., is distinguished from Basopollis orthobasalis by its more prominent concave triangular shape, thinner walls, and the presence of arci. The outer surfaces of Basopollis basalis, $B$. atumescens, and $B$. ornatus are smooth in contrast to the distinctly sculptured outer surface of Basopollis obscurocostatus.

Stratigraphic distribution. - Nanafalia, Wilcox, Pendleton, and Hatchetigbee Formations.

\section{Genus CHOANOPOLLENITES Stover, 1966}

Type species. - Choanopollenites eximius Stover, 1966 (in Stover and others, 1966), Kansas Univ. Paleont. Contr. Paper 5, p. 8, pl. 4, figs. 1a-1h.

The genus Choanopollenites and the stratigraphic distribution of its species have been discussed in a previous publication (Tschudy, R. H., 1973b). In that publication the following new species were proposed: Choanopollenites consanguineus, C. transitus, C. discipulus, C. conspicuus and C. patricius. Two other possible new species were mentioned but not named, owing to an inadequate number of good specimens.

cf. Choanopollenites sp.

Plate 1, figures 13-15; text figure 2

Sample D3138, slide 4, coordinates $88.5 \times 13.2$.

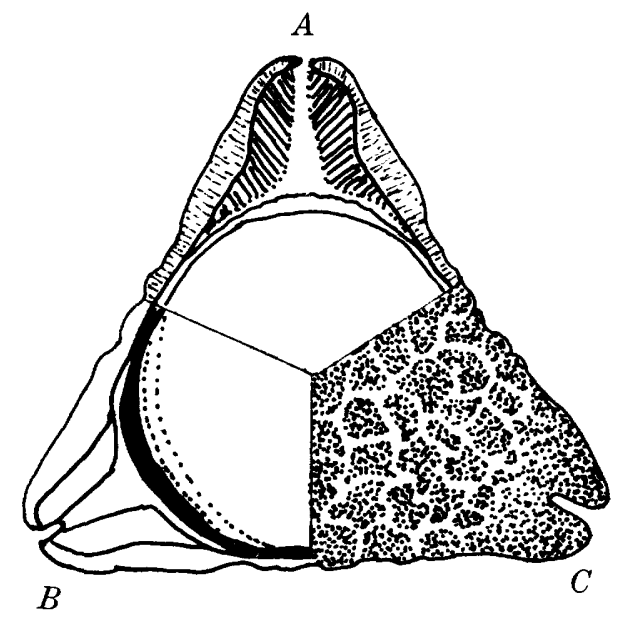

Figure 2. - cf. Choanopollenites sp., ca. $\times 2,000 . A$. Aperture in polar view showing external prismatic layer and internal baculate layer. $B$, Same, showing the two endexinal flaps, one above the other. $C$, Surface view showing ornamentation. 
Description. - Shape of pollen grain triangular in polar view; apertures at the angles. Size $26 \mu$ in equatorial diameter (one specimen). Wall about $1.5 \mu$ thick in interapertural areas, ektexine about twice as thick as endexine. Surface coarsely fossulate. Exogerminals vertical slit shaped. Ektexine in germinal areas two layered, the outer layer columellate (prismatic) structured, narrow adjacent to apertures, then becoming distinctly thicker toward the roots of the germinals. Inner layer of prominent, radially directed bacula. Interior of exogerminals narrow funnel shaped, wider at base than at tip. Vestibulum narrow. Endogerminal equatorial slit shaped bordered by cresent-shaped somewhat thickened lips of endexinal flaps. Endexine structureless, thinner in interapertural areas than adjacent to the endogerminals.

Stratigraphic distribution. - Naheola Formation only.

Genus COMPLEXIOPOLLIS Krutzsch, 1959, emend. Tschudy, 1973b

Type species. - Complexiopollis praeatumescens Krutzsch, 1959, Palaeontographica, ser. B, v. 105, p. 135, pl. 31, figs. $39-54$.

The genus Complexiopollis and the stratigraphic distribution of species from the Mississippi embayment assigned to the genus were presented in a previous publication by R. H. Tschudy (1973b). The following new species from Mississippi embayment rocks were proposed: Complexiopollis funiculus, C. patulus, C. abditus, and C. microverrucatus. One other possible new species was mentioned but, because too few specimens were found, was not named.

\section{Genus EXTREMIPOLLIS Krutzsch, 1967}

Type species. - Extremipollis maastrichtiensis Krutzch, 1967 (in Góczán and others, 1967), Paläontologische Abhandlungen, ser. B, v. 2, no. 3, p. 463, pl. 6, figs. $7-10$.

Diagnosis. - (From Krutzsch, in Góczán and others, 1967). Pollen grains spherical to triangular shallow lens shaped; exogerminals equatorial, located at the angles. Exogerminals provided with three pairs of club-shaped to blunt elongate monannulate annuli. Inner part of annuli sometimes with structure. Exopores vertical slit shaped, somewhat symmetrical to the equator, mostly gaping. Endogerminals with deep incidence to platea (similar to many Trudopollis species). Wall several layered, ratio of the outer to the inner complex about 1:1. Sculpture various. Structure seldom present in the extragerminals. No oculi, endannuli, arci, plicae; only seldom a weak interloculum. Medium-sized forms.

Remarks. - Distinguished from Extratriporopollenites by the presence of a strong incidence or cuneus, and ektexine and endexine of virtually the same thickness. Distinguished from Extrapollis by the absence of a collarlike structure at the root of the germinals.

Extremipollis vivus, n. sp.

Plate 2, figures 1-10; text figure 3

Holotype. - Sample D3420, slide 2, coordinates $95.2 \times 21.0$, McNairy Sand Member, Ripley Formation, Kentucky, Maestrichtian.

Paratype. - Sample D3420, slide 4, coordinates $94.4 \times 21.0$, McNairy Sand Member, Ripley Formation, Kentucky, Maestrichtian.

Diagnosis. - Shape of pollen grains triangular to slightly concave triangular in polar view. Apertural areas prominently protruding; exclusive of apertural areas, pollen grains almost circular in equatorial outline. Size $20 \mu-29 \mu$ in equatorial diameter (18 specimens). Wall of two principal layers about $1.5 \mu$ thick in the interapertural areas. Surface shallowly fossulate, almost smooth. Ektexine and endexine of about equal thickness in interapertural areas. Ektexine thickened, annulate and made up of two layers in the apertural areas; outer layer structureless, inner layer consisting of tightly packed, radially directed elongate bacula; presence of bacula difficult to distinguish in most specimens except at the inner part of the exogerminals. Exogerminals vertical slit shaped, slightly eccentric to the equator, sometimes gaping. Vestibulum narrow and almost absent. Endexine thin, less than $1 \mu$ thick, separated from ektexine by a narrow interloculum. Endopores about $4 \mu$ wide bordered by small endannuli. A prominent semicircular cuneus is present below each endopore.

Remarks. - This species is distinguished from $E x$ tremipollis maastrichtiensis by its concave rather than convex triangular equatorial outline and by its more elongate exogerminals. Many specimens were observed in sample D3420.

Stratigraphic distribution. - McNairy Sand Member, Ripley Formation.

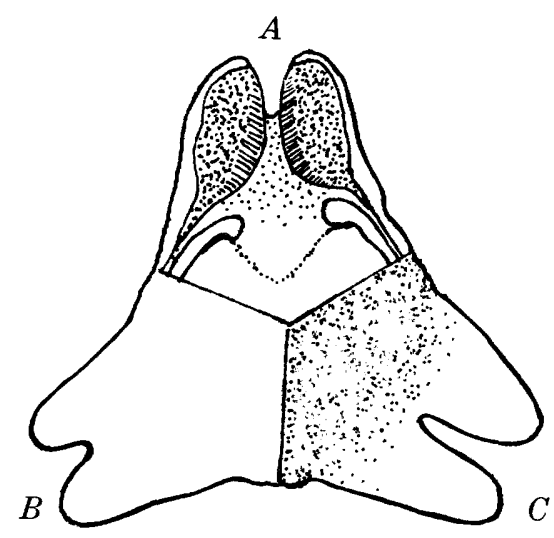

FIGIRE 3. - Extremipollis vivus, ca. $\times 2,000$. A. Section view of germinal. $B$, Slit-shaped exogerminal showing short slit on one side of grain. Compare with $C$. $C$, Long slit on obverse side of grain. Surface ornamentation shown. 
Extremipollis versatilis, n. sp.

Plate 2, figures 11-22; text figure 4

Holotype. - Sample D3420, slide 3, coordinates $97.6 \times 11.5$, McNairy Sand Member, Ripley Formation, Kentucky, Maestrichtian.

Paratype. - Sample D3420, slide 3, coordinates $108.2 \times 5.3$, McNairy Sand Member, Ripley Formation, Kentucky, Maestrichtian.

Diagnosis. - Shape of pollen grains triangular in polar view; apertural areas sometimes protruding and interrupting the triangular outline. Size $23 \mu-31 \mu$ in equatorial diameter ( 25 specimens). Wall of two principal layers, about $2 \mu$ thick in interapertural areas. Surface coarsely fossulate. Ektexine of about same thickness as endexine or slightly thicker in interapertural areas. Ektexine prominently annulate and made up of two layers adjacent to the aperrtures; outer layer structureless, inner layer of prominent radially directed bacula. Exogerminals vertical slit shaped, slightly eccentric to the equator, seldom gaping. Vestibulum narrow, almost absent, present only at the extreme root of the exogerminals. Endexine thin, commonly less than $1 \mu$ thick and separated from the ektexine by an interloculum. Endopores $5 \mu-6 \mu$ wide; a prominent semicircular to somewhat $V$-shaped cuneus present below each endopore. Inner lamella of endexine forming an inconspicuous additional atrium in some specimens.

Remarks. - Distinguished from Extremipollis vivus by the absence of endannuli, less protruding exogerminals, and coarser sculpture. Many specimens present in sample D4268-A. Several apparently somewhat transitional forms were observed. This variation is demonstrated by apparently thinner endexine and slightly more narrow and protruding exogerminals (pl. 2, figs. 20-22).

Stratigraphic distribution. - Coffee Sand, Coon Creek Tongue of Ripley Formation, and McNairy Sand Member of Ripley Formation.

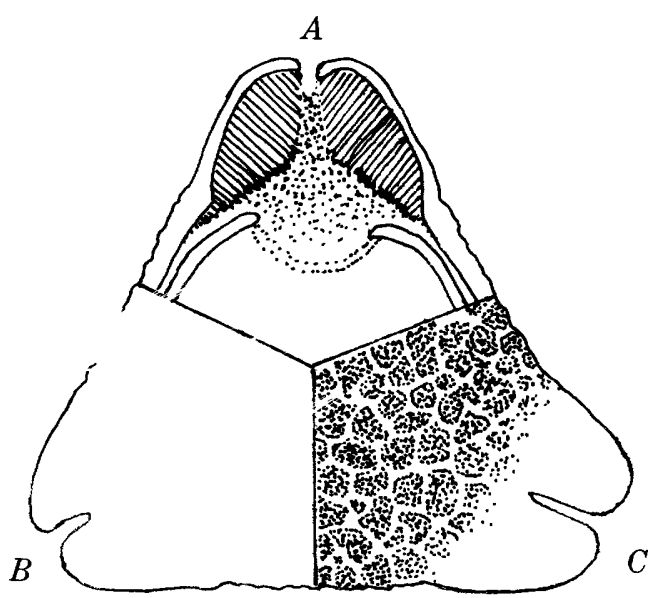

Figure 4. - Extremipollis versatilis, ca. $\times 2,000$. A, Sectional view of germinal. $B$, Short slit on one side of grain. $C$, Elongate slit on obverse side of grain. Surface ornamentation shown.
Extremipollis caminus, n. sp.

Plate 3, figures 1-18; text figure 5

Holotype. - Sample D3420, slide 4, coordinates $79.7 \times 4.5$, McNairy Sand Member, Ripley Formation, Kentucky, Maestrichtian.

Paratype. - Sample D3420, slide 2, coordinates $84.3 \times 14.8$, McNairy Sand Member, Ripley Formation, Kentucky, Maestrichtian.

Diagnosis. - Shape of pollen grains triangular to slightly concave triangular in polar view with prominent chimneylike protrusions (germinals) at the angles. Size $25 \mu-41 \mu$ in equatorial diameter ( 30 specimens). Wall of two principal layers, about $1.5 \mu$ thick in the interapertural areas. Surface microverrucate with low relief.
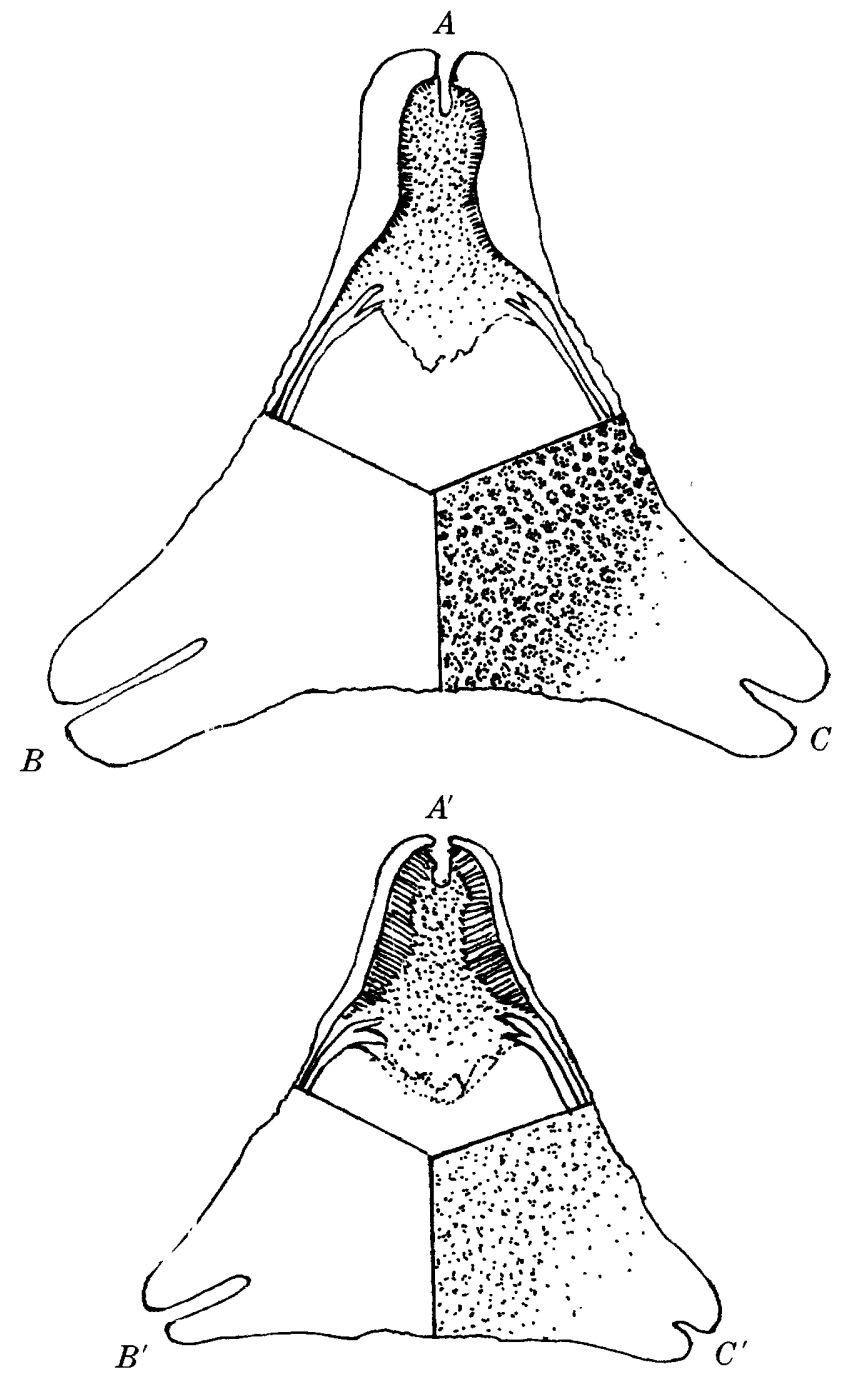

Figure 5. - Extremipollis caminus, ca. $\times 2,000 . A$ and $A^{\prime}$, Sectional view of aperture showing variation in development of the visible baculate layer and the splitting of the endexine at the margins of the endogerminals. $B$ and $B^{\prime}$, Elongate apertural slit present on one side of grain is in contrast with length of slit on obverse side. $C$ and $C^{\prime}$, Short apertural slit of exogerminal on obverse side; variation of surface sculpture of small and large specimens is also shown. 
Ektexine and endexine of about equal thickness in interapertural areas. In germinal areas the ektexine is greatly thickened and structureless in the outer part; the inner part appears lined with short radially projecting bacula. Exogerminals vertical slit shaped, distinctly eccentric to the equator (one side of slit extends a much greater distance toward the pole than does the other side). Neck of exogerminal area with a prominent biconvex chamber widens toward the base. Vestibulum narrow and present only at the base of the exogerminal. Endexine thin, about $0.5 \mu$ thick and separated from the ektexine by a narrow interloculum. Endopore $6 \mu-7 \mu$ wide subtended by a prominent $U$ - or $V$-shaped cuneus. Endexine commonly splitting into two or more lamellae adjacent to the endopore.

Remarks. - This species is distinguished from all other species of Extremipollis by the long chambered neck of the exogerminal. The two drawings in text figure 5 show variation in the development of the ektexinal baculate layer and the finer surface ornamentation present on the smaller specimens.

Stratigraphic distribution. - McNairy Sand Member, Ripley Formation.

\section{Genus INTERPOLLIS Krutzsch, 1960}

Intratriporopollenites supplingensis Pf., 1953 (in Thomson and Pflug, 1953), Palaeontographica, v. 94, ser. B, p. 89, pl. 10, fig. 26.

Type species. - Interpollis supplingensis (Pf.) Krutzsch, 1960, Geol. Gesell DDR. Berichte, v. 5, no. 4, p. 305 .

Diagnosis. - ("New wording" from Góczán and others, 1967.) Pollen grains triangular double-lens shaped, owing to an equatorial constriction, seldom single lens shaped because of a reduced constriction. Subequatorial contour mostly weakly convex triangular, sometimes also weakly concave triangular, seldom rounded triangular. Equatorial contour primarily strongly concave triangular with projecting rounded sectors at the angles. The polar regions often somewhat depressed and limited by band-shaped arcilike angle-toangle differentiation of both hemispheres. Wall two layered, ratio of ektexine to endexine about $1: 1$; walls sometimes separated by weak local interloculi. Surface smooth or weakly sculptured; inner layer often intrapunctate. Germinals at the angles without annuli, with two small, somewhat round subequatorial proximal and distal exopores at each angle. The endopores are at the equator. The structured inner wall layer sometimes forms a distinct visible atrium. Forms small to maximum middle sized.

Interpollis cf. I. supplingensis (Pf.) Krutzsch, 1960b Plate 4, figures 1-21; text figure 6

Type specimen. - (Lectotype designation, Pflug, 1953, pl. 24, fig. 39).

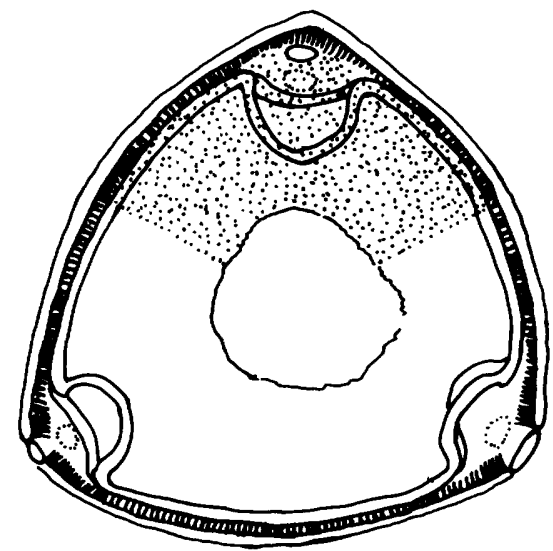

A

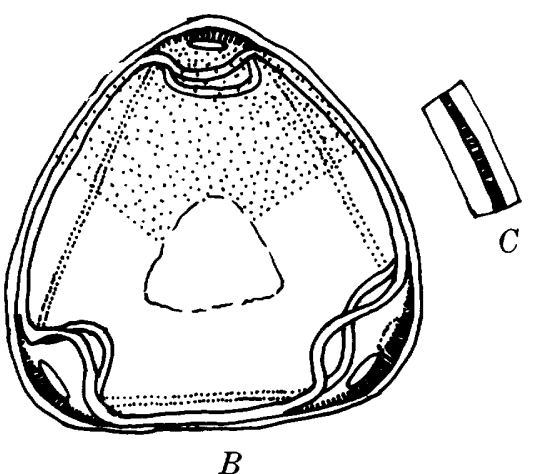

Figure 6. - Interpollis cf. I. supplingensis, ca. $\times 2,000 . A$, Large specimen in which baculate interloculum shows clearly. $B$, Smaller specimen. Triangular equatorial contour shown on this figure. $C$, Bacula in interloculum visible only under oil immersion lens.

Synonymy. - Intratriporopollenites supplingensis Pf., in Thomson and Pflug, 1953.

Interporopollenites supplingensis Pflug, 1953. Interpollis supplingensis (Pf.) Krutzsch, 1960b.

Remarks. - Interpollis supplingensis was first described by Pflug (in Thomson and Pflug, 1953) as Intratriporopollenites supplingensis. In a succeeding volume, Pflug (1953) transferred the species to Interporopollenites supplingensis without adding to the original diagnosis. Later, Krutzsch (1960b), after noting the presence of six exopores and an equatorial constriction, erected the new genus Interpollis and chose the species Interpollis supplingensis as the type species. Krutzsch did not provide a new diagnosis for the species, even though the original diagnosis by Pflug (in Thomson and Pflug, 1953) was extremely brief and inadequate. I am therefore including here a description of the Mississippi embayment forms that are similar to or conspecific with Interpollis supplingensis. This is not intended as an emendation.

Description. - Shape of pollen grains triangular to almost circular, equatorial constriction prominent in some specimens, in others scarcely evident. Size $16 \mu-30 \mu$ 
(30 specimens) in equatorial diameter, most grains in the $20 \mu-25 \mu$ size range. Wall two layered, thin, about $1.5 \mu-2 \mu$ thick; ektexine and endexine of about the same thickness separated by a very narrow baculate layer. Extexine smooth, appearing granulate except in polar areas; granulate appearance due to presence of short bacula between ektexine and endexine. Appearance of polar scar or thin area is due to absence of bacula. Baculate layer of ektexine distinctly thicker in atria than in interapertural areas. Exogerminals six, two at each angle of grains, subequatorial or nearly so, one on each hemisphere; apertures circular or slightly elongate equatorially. Endogerminals three, equatorial, somewhat hourglass shaped in equatorial view, without annuli; endexine separated from ektexine in apertural areas by a vestibulum.

Remarks. - The original diagnosis lists the size of this species as $18 \mu-40 \mu$. I found only three specimens as large as $28 \mu$, and two specimens in the $16 \mu$ range. The equatorial constriction is shown particularly well on plate 4, figures 6-13 and 16-18.

Stratigraphic distribution. - Cusseta Sand Member of Ripley Formation, Coon Creek Tongue of Ripley Formation, McNairy Sand Member of Ripley Formation, upper part of McNairy Sand, and Owl Creek Formation. One poor specimen (redeposited?) was observed in the Naborton Formation.

Interpollis microsupplingensis Krutzsch, $1960 \mathrm{~b}$

Plate 4, Figures 22-25

Diagnosis. - (From Krutzsch, 1960b.) A very small form-species of Interpollis. Size $10 \mu-20 \mu$, in section $14 \mu-17 \mu$. Double-lens shaped. Equatorial contour concave triangular, subequatorial contour strongly triangular to weakly convex triangular. Surface shagrenate to finely extrapunctate.

Remarks. - Exopores very small, circular, about $1 \mu$ in diameter. Mississippi embayment specimens conform very well to the circumscription and illustrations of Interpollis microsupplingensis.

Stratigraphic distribution. - Hatchetigbee and Reklaw Formations.

Interpollis intranodus, $n$. sp.

Plate 5, figures 1-15; text figure 7

Holotype. - Sample D3285, slide 1, coordinates $90.3 \times 15.3$, Porters Creek Clay, Kentucky, Paleocene.

Paratype. - Sample D3285, slide 2, coordinates $97.7 \times 21.7$, Porters Creek Clay, Kentucky, Paleocene.

Diagnosis. - Shape of pollen grain convex-triangular, equatorial constriction not evident on most specimens. Size $20 \mu-36 \mu$ in equatorial diameter (11 specimens). Wall two layered, about $2 \mu$ thick. Ektexine and endexine of about equal thickness. Ektexine undulate to microrugulate, two layered; the outer layer structureless, the inner consisting of very short fine bacula. Bacula

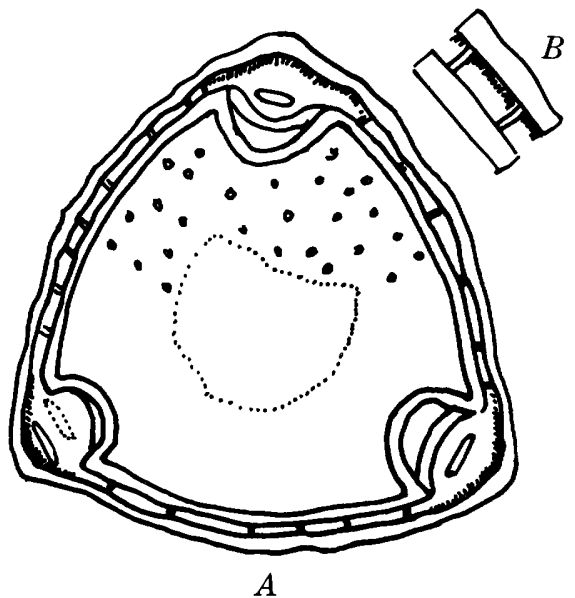

Figure 7. - Interpollis intranodus, ca. $\times 2,000 . A$, Peglike bacula visible in interloculum and in surface view. $B$, Wall layers with large peglike bacula and also small dense bacula attached to ektexine.

present except in polar areas. Interloculum prominent; scattered interlaminar short peglike bacula or gemmae separate endexine from ektexine. Exopores equatorially elongate, small, six in subequatorial pairs at the angles, not clearly evident on all specimens. Endopores in endexine, and atria almost identical to those found in Interpollis c.f. I. supplingensis.

Remarks. - Distinguished from other species of Interpollis by the presence of scattered coarse bacula or gemmae separating the endexine and ektexine. Surface views of peglike bacula show particularly well on plate 5 , figures 1 , and $13-15$.

Stratigraphic distribution. - Owl Creek and Clayton Formations, Porters Creek Clay, and Naheola Formation.

Genus INTERPOROPOLLENITES Weyland and Krieger, 1953

Type species. - Interporopollenites proporus Weyland and Krieger, 1953, Palaeontographica, ser. B. v. 95, p. 20 , pl. 1 , fig. 34 .

Diagnosis. - ("New wording" from Góczán and others, 1967.) Compact triangular lens shaped; those with a weak equatorial constriction slightly double lens shaped. Equatorial contour from concave triangular to nearly circular. Polar axis always shorter than the equatorial axis. Wall always at least two layered; if more, two principal wall complexes recognizable; ratio of ektexine to endexine $1: 1$ to $1: 5$ and more. Sometimes without arci but mostly with arci, these very distinct in form and distribution (breadth, thickness, course); sometimes only plicalike folds present. Surface smooth to weakly sculptured; wall sometimes with structure (punctate, baculate). Seldom with an interloculum, in most species, however, with an endannulus. Endopores equatorial, at angles, mostly round to oval, never with strong incidence, cuneus, and so forth; inner lamella layer tightly attached. Six exopores present, at the 
angles, one of each pair subequatorial on the distal and one on proximal side; exopores round, oval or polygonal, never very large; these may also be located somewhat laterally. The exogerminal is closed at the equator, and in some form-species this area may be thickened annuluslike to pointed. Forms small to medium-sized, very seldom larger representatives.

\section{Interporopollenites turgidus, $n$. sp.}

Plate 6, figures 1-18; text figure 8

Holotype. - Sample D3548-A, slide 1, coordinates 77.5×11.8, Clayton Formation, Kentucky, Paleocene.

Paratype.- Sample D3548-A, slide 2, coordinates $78.4 \times 6.5$, Clayton Formation, Kentucky, Paleocene.

Diagnosis. - Pollen grains triangular in polar view with very prominent hemispherical protrusions at the angles. Size $24 \mu-29 \mu$ in equatorial diameter (10 specimens); hemispherical corner protrusions about onethird the diameter of the grains. Wall of two principal layers; the ektexine in the interapertural areas thin, about $0.5 \mu$ thick, in the apertural areas much thicker, owing to the presence of an additional internal baculate layer. Endexine much thicker than ektexine, in the interapertural areas $2 \mu-3 \mu$ thick. Ektexine usually smooth, faint granular arcuslike sculpture extending from aperture to aperture present on some specimens. Two small exogerminals present in each of the three germinal areas, one on each side subequatorially; germinal pores may be elongate equatorially or in the polar direction. Exogerminal wall $2 \mu-3 \mu$ thick, thinner toward the root of the prominent vestibulum. Bacula in the interior of the exogerminal areas very abundant and tightly packed, often somewhat difficult to observe. Endogerminal in the form of a circular equatorial pore, much larger than the exogerminal pores. Endexine adjacent to the pores with endannuli as much as $5 \mu$ thick; endexine in pore area may be split into several distinct lamellae.

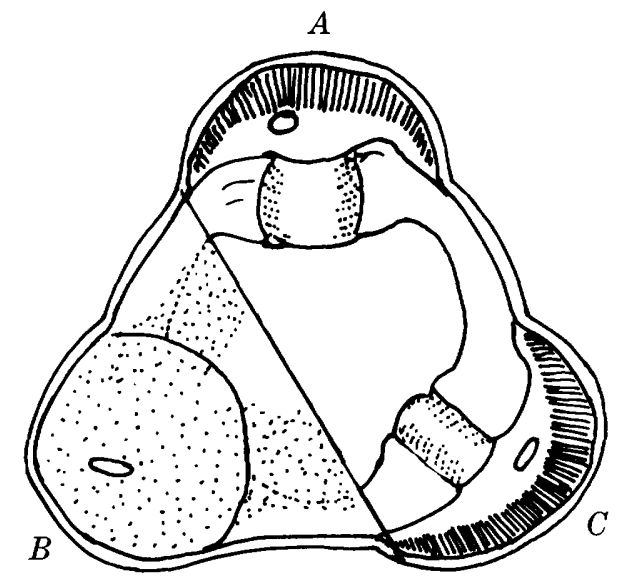

FIGURE 8. - Interporopollenites turgidus, ca. $\times 2,000 . A, B$, Sectional views of apertures showing baculate areas, thick endexine, large equatorial endexinal pores and small nonequatorial exopores. $C$, Surface view showing nonequatorial exopore and faint arci.
Remarks. - Distinguished from Interporopollenites proporus by the faint arcuslike exterior sculpture and by the thickened ektexine in the exogerminal area.

Stratigraphic distribution. - Clayton Formation and Porters Creek Clay.

\section{Genus KYANDOPOLLENITES Stover, 1966}

Type species. - Kyandopollenites anneratus Stover (in Stover and others, 1966), Kansas Univ. Paleont. Contr. Paper 5, p. 6, pl. 3, figs. 1, 2.

Diagnosis. - (From Stover, 1966.) "Pollen isopolar, triaperturate; apertures aspidate, equatorial, compound. Outer aperture circular or nearly so, inner aperture elliptical, elongate. Grains circular in polar view, oblate in equatorial view. Exine relatively thick $(5 \mu-8 \mu)$, sexine thicker than nexine; endosexine lacking or very thin around apertures. Surface granulate on type species. Monotypic."

\section{Kyandopollenites anneratus Stover, 1966 \\ Plate 7, figures 1-5; text figure 9}

Remarks. - Although Stover (in Stover and others, 1966) did not definitely assign Kyandopollenites to the Normapolles group, he did compare the genus with two Normapolles genera, Emscheripollis and Papillopollis. The size range of Kyandopollenites given by Stover is $47.5 \mu-54 \mu$. Specimens measured from our material increase the range slightly to $41 \mu-58 \mu$

Stratigraphic distribution. - Wilcox and Pendleton (Andersen, 1960) Formations.

\section{Genus MEGATRIOPOLLIS Góczán and Krutzsch, 1967}

Type species. - Megatriopollis santonius Groot and Krutzsch, 1967 (in Góczán and others, 1967), Paläontologische Abhandlungen, ser. B, v. 2, no. 3, p. 477, pl. 10 , figs. 17-22.

Diagnosis. - (From Góczán and Krutzsch, in Góczán and others, 1967.) Pollen grains triangular shallow lens shaped, equatorial contour triangular to triangular convex. The equatorial contour of the inner part of the pollen grains is circular (rund bis überrund). Wall of two principal layers, the outer thicker than the inner, the latter sometimes very thin. Surface variously strongly sculptured; sometimes with a structured layer in the inner part of the wall. Tendency to a "Schichtfuge" or interloculum between the two wall layers. Exogerminal with annulus or tumescens, it is, however, monannulate, although sometimes showing fine structure in the inner part. Exopores vertical slit shaped, lying weakly asymmetrical to the equator. With vestibulum. Endogerminal without essential thickening, with a fairly wide endopore that is generally bounded by a shallow atrium. The opening of the innermost wall layer is similarly formed. No oculi, arci, plicae, and so forth. Forms medium sized. 

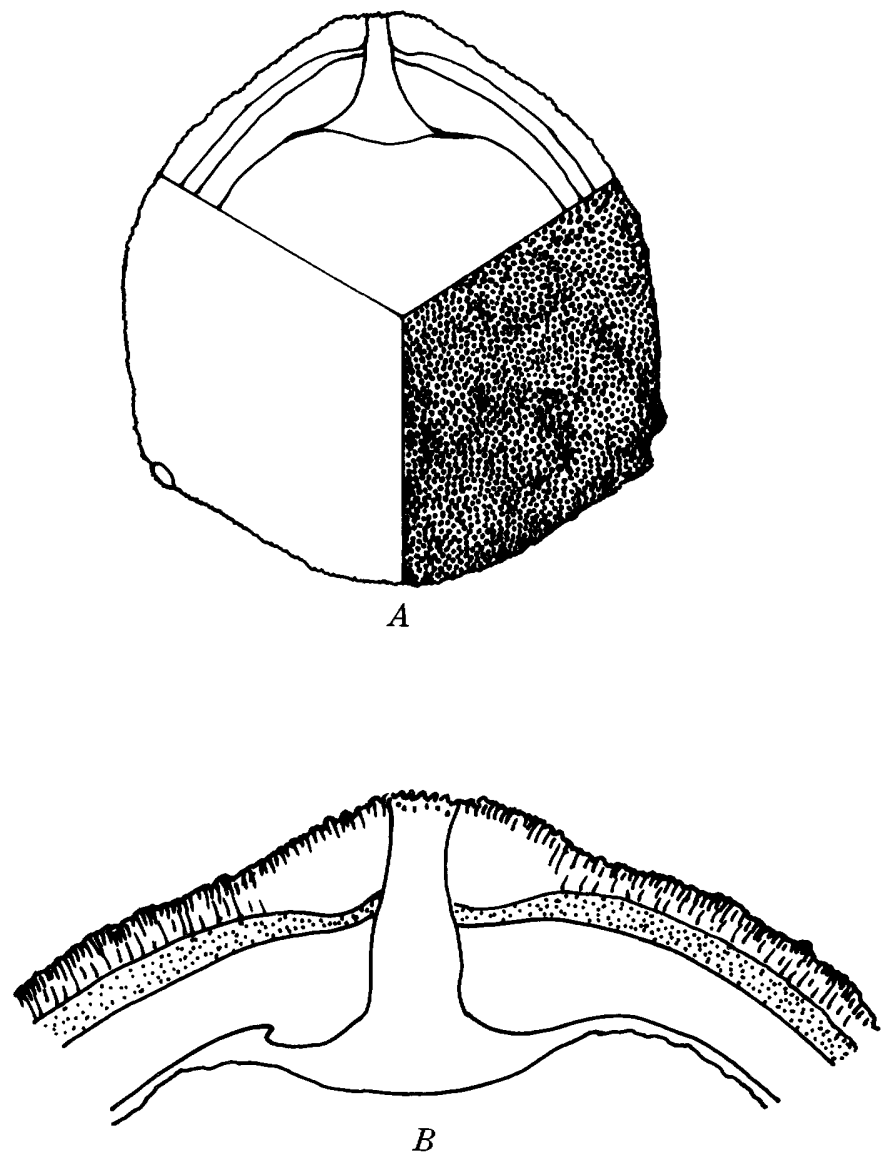

Firilki: 9. - Kyandopollenites anneratus Stover, 1966. A, Pollen grain, ca. $\times 1,000$, showing sectional view of aperture and surface sculpture. $B$. Sectional view of pore, $\times 2,000$, showing three prominent wall layers.

\section{Megatriopollis? sp.}

Plate 7, figures 6-10; text figure 10

Description. - Shape of pollen grains triangular to slightly convex-triangular in polar view. Size $25 \mu-29 \mu$ in equatorial diameter (two specimens). Wall thin, two layered, $1 \mu-1.5 \mu$ thick in interapertural areas. Surface smooth or finely punctate, owing to the structure of the outer wall. Exogerminals vertical slit shaped, ektexine adjacent to exogerminals in the form of labra, outer part of labra structureless, inner part fine structured, in our specimens radially directed bacula observed. Endexine very thin, separated from ektexine by a narrow interloculum. No discernible vestibulum. Atrium large, with plane or slightly concave inner boundary.

Remarks. - This species was not named, because too few specimens were available. The specimens observed differ from the circumscription of the genus by the absence of a recognizable vestibulum. However, the presence of a vestibulum is not clearly represented in the photographs of the type species.

Stratigraphic distribution. - Coffee Sand and Porters Creek Clay.
Genus MINORPOLLIS Krutzsch, 1959

Type species. - Minorpollis minimus Krutzsch, 1959, Palaeontographica, ser. B, v. 105, p. 141, pl. 32, figs. 10-14.

Diagnosis. - ("New wording" from Góczán and others, 1967.) Pollen triangular shallow lens shaped, seldom somewhat triplanoid because of slightly longer polar axis; equatorial contour round to strongly triangular with sometimes a crooked side contour. Wall two layered, presence distinguishable. Surface smooth to finely sculptured. With three equatorial germinals at the angles; exogerminal with oval to vertical slit-shaped outer opening, with annulus, tumescence, or labrum. Without oculus. Endogerminal variously structured, sometimes with endannulus; endopores displayed as equatorial elongated oval to vertical oval. Sometimes with indications of plicae. Often secondary folding but without solutions. Size: $6 \mu$ to about $15 \mu$; only very small forms assembled here.

\section{Minorpollis minimus Krutzsch, 1959}

Diagnosis. - (From Krutzsch, 1959.) A lens-shaped form-species of Minorpollis with a weak tendency to sinuose folding, somewhat rigid equatorial contour, sometimes with a weak constriction of the Turonipollis type. Exine two layered, very thin, surface shagreenate, exogerminal with long club-shaped annulus. Endexine relatively thick, sometimes with weak endannulus. Endopores equatorially elongate, no typical atrium present. Size $8 \mu-11 \mu$.

\section{Minorpollis aff. M. minimus}

Plate 8, figures 1-9; text figure 11

Description. - Shape of pollen grains triangular with rounded angles in polar view, apertural areas slightly swollen, interrupting the outline. Size $13 \mu-16 \mu$ in equatorial diameter ( 27 specimens). Wall no more than $1 \mu$ thick in interapertural areas, ektexine and endexine of about equal thickness. Ektexine thin, smooth. Exogerminal oval to short vertical slit shaped; ektexine adja-

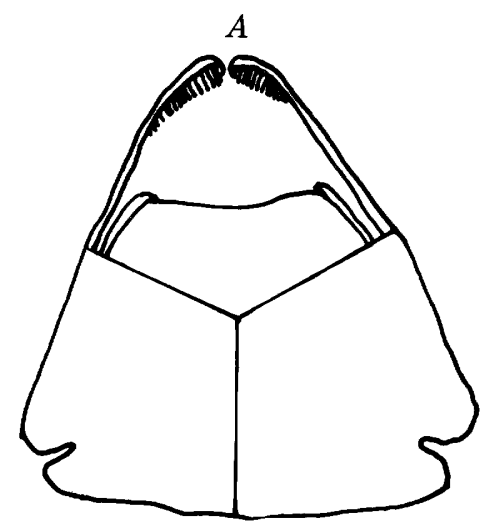

FigtRe 10. - Megatriopollis? sp., ca. $\times 2,000$. Sectional view of aperture $(A)$, showing baculate area adjacent to exogerminal, deep atrium, wide endogerminal, and interloculum. 


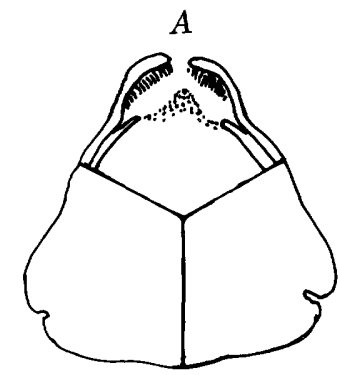

Fisiline 11. - Minorpollis aff. M. minimus, ca. $\times 2,000$. A, Sectional view of aperture showing baculate area and triangular extension of the endexine below the exogerminal.

cent to the exogerminal two layered, the outer layer structureless, the inner layer of short radially projecting bacula. Baculate area readily visible in some specimens, obscure in others; ektexinal walls adjacent to exogerminal annulate to labrate. Endexine thin and with irregular margin below the exogerminal, commonly with a pointed or triangular outward projecting extension. This extension subtends two oval vestibulumlike areas immediately below the baculate layer of ektexine. Endogerminal probably equatorial slit shaped; exogerminal slit smaller.

Remarks. - The specimens found are all larger than the size mentioned by Krutzsch (1959) for Minorpollis minimus $(8 \mu-11 \mu)$. Otherwise our specimens appear to conform to the circumscription of the species. The pollen grains are similar to grains of Pseudoplicapollis serenus except that they do not possess plicae. Furthermore, Minorpollis aff. $M$. minimus has a different stratigraphic range.

Stratigraphic distribution. - Clayton Formation and Porters Creek Clay.

\section{Genus NUDOPOLLIS Pflug, 1953}

Extratriporopollenites endangulatus Pflug, 1953 (in Thomson and Pflug, 1953), Palaeontographica, ser. B, v. 94, p. 72, pl. 6, fig. 37. Nudopollis endangulatus (Pflug) Pflug, 1953, Palaeontographica, ser. B, v. 95 , p. 108 , pl. 25 , fig. 24 .

Type species. - Nudopollis endangulatus (Pf.) Pflug.

Diagnosis. - ("New wording" from Góczán and others, 1967.) Pollen grains triangular shallow lens shaped, the three equatorial germinals located at the angles, sometimes very prominent; germinals monannulate, seldom polyannulate. Equatorial contour from slender concave triangular (with sometimes slightly irregular sides) to triangular concave extending to forms with only slightly elongate exogerminals. Central body round to triangular convex. Without or with weak plicae. Wall variously thick, the outer part mostly thicker than the sometimes thinner inner part. Intermediate development is observed in some form species; for example, in "endangulatus" a fairly pronounced structure layer is developed and enlarged in the germinal region to form the mesopore. Surface smooth to occasionally weakly sculptured. Exopores vertical slit shaped, and weakly asymmetrical to the equator, opening outward, toward the inner part oval-round, that is with a strongly constricted canal ending. Annuli sometimes with distinct structure in the outer wall (punctate-baculate). The mesopore is developed as a basketlike filter. Endogerminal without thickening; endopores formed as large, variously deep, half circular atria. No arci, oculi only as a tendency, interloculum seldom (probably only as a secondary development). Medium-sized forms.

Nudopollis endangulatus (Pflug) Pflug, 1953

Diagnosis. - (From Pflug, in Thomson and Pflug, 1953.) $25 \mu-35 \mu$. Contour strongly triangular to weakly concave. Inner contour convex triangular, not circular. Long pore canal. Annulus with pointed tip. Endexine thinner than ektexine, mostly very thin, the ektexine closely appressed at all points. No solution meridian, exine shagreenate.

\section{Nudopollis aff. $\mathbf{N}$. endangulatus}

Plate 8 , figures $10-11$

Remarks. - Few specimens found. Both the ektexine and the endexine are very thin in interapertural areas. "Filter apparatus" very poorly developed in $N$. endangulatus in contrast to its development in $N$. terminalis.

Stratigraphic distribution. - Nanafalia Formation.

Nudopollis terminalis (Thomson and Pflug) Pflug, 1953

Extratriporopollenites terminalis Thomson and Pflug, 1953, Palaeontographica, ser. B, v. 94 , p. 71, pl. 6, fig. 31 .

Nudopollis terminalis (Thomson and Pflug) Pflug, 1953, Palaeontographica, ser. B, v. 95, p. 161, pl. 22, figs.1-6.

Diagnosis. - (From Pflug and Thomson, 1953.) $20 \mu-24 \mu$. Contour convex. Inner contour more triangular than round. Pore canal not more than $8 \mu$ long, centripetally conically expanded. Without vestibulum but with atrium. Endexine at best half as thick as ektexine. Exine smooth to shagreenate, at the atrium intrabaculate.

\section{Nudopollis terminalis subsp. hastaformis \\ Diagnosis. - Annulus with pointed tips.}

\section{Nudopollis terminalis subsp. hebeformis}

Diagnosis. - Annulus with blunt tips.

Remarks. - Extratriporopollenites terminalis, including the two subspecies, was transferred to Nudopollis terminalis by Pflug (1953) on the explanation of plate 22, p. 161 . The subspecies $N$. hastaformis according to the International Rules of Botanic Nomenclature must become Nudopollis terminalis terminalis. However, the illustrations of the two subspecies do not clearly distinguish the two. Variation within the species is such that no good purpose is served by attempting to recognize the subspecies. They are mentioned here as a means of including the complete original diagnosis. 
Nudopollis aff. N. terminalis (Thomson and Pflug) Pflug, 1953 Plate 8 , figures $16-25$

Remarks. - The specimens illustrated most closely approximate Nudopollis terminalis terminalis. There is a recognizable stratigraphic size difference observed in this species. The Paleocene specimens range from $22 \mu$ to about $30 \mu$ in equatorial diameter, whereas those from the Eocene range from $22 \mu$ to about $38 \mu$ in equatorial diameter. No specimens larger than $30 \mu$ were observed in Paleocene or older samples. The size range of $N$. terminalis given by Thomson and Pflug is $20 \mu-40 \mu$.

Stratigraphic distribution. - All formations from Porters Creek Clay through the Cockfield Formation.

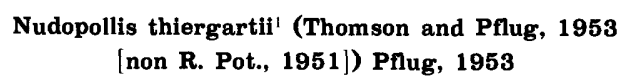

Extratriporopollenites thiergarti Thomson and Pflug, 1953. Palaeontographica, v. 94, ser. B., p. 71, pl. 6, fig. 43 Nudopollis thiergarti (Thomson and Pflug) Pflug, 1953, Palaeontographica, v. 95, ser. B., p. 109.

Nudopollis thiergarti (Thomson and Pflug, 1953 [non R. Pot. 1951]) Pflug, 1953. Berichte Geol. Gesel DDR., v. 5, no. 4, p. 326 (Lectotype designation by Krutzsch, 1960b).

Diagnosis. - (From Thomson and Pflug, 1953.) $12 \mu-35 \mu$. Contour convex to weakly concave, inner contour always circular. Endexine tightly appressed to ektexine, scarcely recognizable, without solution meridian or with it only intimated. Rodlet layer not evident. Exine shagreenate to faded intrarugulate. Pore canal sometimes gaping centrifugally. Praevestibulum sometimes suggested.

\section{Nudopollis thiergartii subsp. meridium Pflug, 1953, in Thomson and Pflug, 1953}

Diagnosis. - $25 \mu-50 \mu$. Small canal-shaped solution meridian, exine smooth to shagreenate. Ektexine in interapertural areas less than $2 \mu$ thick. Contour concave.

\section{Nudopollis thiergartii subsp. conspicuus Pflug, 1953, in Thomson and Pnug, 1953}

Diagnosis. $-25 \mu-35 \mu$. Contour mostly concave to interrupted concave. No solution meridian. Shallow fossulate sculpture. Ektexine in interapertural areas more than $2 \mu$ thick.

\section{Nudopollis thiergartii subsp. minutus Pflug, 1953, in Thomson and Pflug, 1953}

Diagnosis. $-12 \mu-25 \mu$. Contour mostly weakly convex. Minute semicircular solution meridian. Shallow fossulate sculpture. Ektexine in interapertural areas less than $2 \mu$ thick.

Remarks. - The species Nudopollis thiergartii is discussed in detail by Krutzsch (1960b, p. 326). Krutzsch designated the specimen plate 6 , figure 43 , of Thomson and Pflug (1953) as the lectotype. This specimen was originally designated as Nudopollis thiergartii subsp. conspicuus. Krutzsch called attention to the fact that according to International Rules of Botanic

\footnotetext{
Originally spelled thiergarti. International Code of Botanical Nomenclature, Article 73
} recommends the change from " $\mathrm{i}$ " to "ii" when the name of a person ends in a consonant.
Nomenclature this subspecies must be designated as Nudopollis thiergartii subsp. thiergartii. Both Pflug (1953, p. 109) and Krutzsch (1960b, p. 326) indicated that this species is variable and complex. Diagnoses of subspecies included here for completeness.

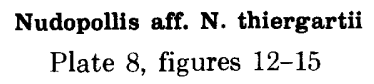

Remarks. - Fairchild and Elsik (1969) indicated that this species is present in the Paleocene and early Eocene and becomes virtually extinct at the end of early Eocene time.

Stratigraphic distribution. - McNairy Sand through the Tallahatta Formation in our reference samples.

\section{Genus PECAKIPOLLIS Kr. and Paclt., 1967}

Type species. - Pecakipollis bohemiensis $\mathrm{Kr}$. and Paclt., 1967, Palaontologische Abhandlungen, ser. 8, v. 2, no. 3 , p. 486 , pl. 12 , figs. $14-20$.

Diagnosis. - (From Kr. and Paclt., in Góczán and others, 1967.) Pollen grains triangular shallow lens shaped, equatorial contour interrupted triangular to circular. Equatorial contour of the central body circular, the three equatorial germinals at the angles affect the contour strongly. Wall of two principal layers, ratio of about 1:1, not thick, without structure. Surface with weak sculpture, punctate, shagreenate to weak irregularly wrinkled. No interloculum. Exogerminals with slightly thickened plump labra, thereby forming a large vestibulum. Exopore weakly vertical slit shaped to elongate oval, outer opening arranged weakly asymmetric to the equator. On inspection the exogerminal appears as a shallow to equilateral triangle, or correspondingly a blunt-tipped trapezoid. The outer opening of the endogerminal is constructed of an equatorial elongate slit in the outer lamella with a straight or weakly convex outer margin. The inner opening is constructed by one or more broad fringed to jaggedappearing atria formed by the divided ends of the lamellae on both sides of the inner opening. No (or in any case, no typical) plicae, arci, oculi, and so forth, are developed. Forms small to at most medium sized.

$$
\text { cf. Pecakipollis sp. }
$$

Plate 9, figures 1-5; text figure 12

Remarks. - One specimen, $23 \mu$ in equatorial diameter, was found. This specimen appears to possess most of the characteristics of Pecakipollis. The ektexine of this specimen is $1.5 \mu-2 \mu$ thick, very much thicker than the endexine. A "Schichtfuge" appears to be present between the ektexine and endexine. The ends of short bacula can be seen in the large vestibula. Insufficient specimens were found to provide an adequate evaluation of this taxon.

Stratigraphic distribution. - Coon Creek Tongue of Ripley Formation. 
Genus PliCAPOLlis Pflug, 1953, emend. Tschudy

Type species. - Plicapollis serta Pflug, 1953, Palaeontographica, v. 95, ser. B, p. 97, pl. 19, figs. 7-9.

Diagnosis. - Pollen grains triangular flat lens shaped to triplanoid. Equatorial contour varies from triangular convex to triangular concave. Wall of two principal layers, ratio about 1:1, surface sculpture smooth to verrucate. With plicae, these generally prominent. Three germinals equatorially arranged at the angles. Exogerminals usually with somewhat strong annuli; annuli sculptured on the inner face with radial bacula, sometimes strongly, sometimes less so. Pore canal index less than 0.3 . Exopores shallowly vertical slit shaped to circular, commonly symmetrical with the equator. With vestibula. Endogerminals slightly to strongly thickened adjacent to the somewhat equatorial slit shaped to oval or circular endogerminals (seen in equatorial view); in polar view, they possess a somewhat straight to weakly convex or concave boundary. No arci, no oculi; a "Schichtfuge" or narrow interloculum may be present. Mostly small to medium-sized forms.

Remarks. - In the original short diagnosis, Pflug (1953) referred to Plicapollis as tricolporate with pores all equatorial. Góczán and others (1967) enlarged upon the diagnosis without emending it, as follows:

Diagnosis. - ("New wording" from Góczán and others, 1967.) Pollen grains triangular flat lens shaped to triplanoid. Equatorial contour varies from triangular convex to triangular concave. Wall with two principal layers, ratio about $1: 1$, surface mostly smooth. With plicae, these more or less prominent, sometimes reduced. Three germinals equatorially arranged at the angles. Exogerminals with somewhat strong annuli; annuli sculptured on the inner face with radial bacula, sometimes strongly, sometimes less so. Pore canal index less than 0.3 . Exopores vertical slit shaped, terminating outward, mostly approximately symmetrical with the equator. With vestibulum. Endogerminals not thickened, with somewhat equatorial slit shaped to elongated oval pores (seen in equatorial view); in polar view they possess a more or less straight to weakly convex or concave boundary. No arci, no oculi, no interloculum. Mostly small to medium sized forms.

Góczán and others (1967) categorized the exogerminals as being vertical slit shaped and stated that the

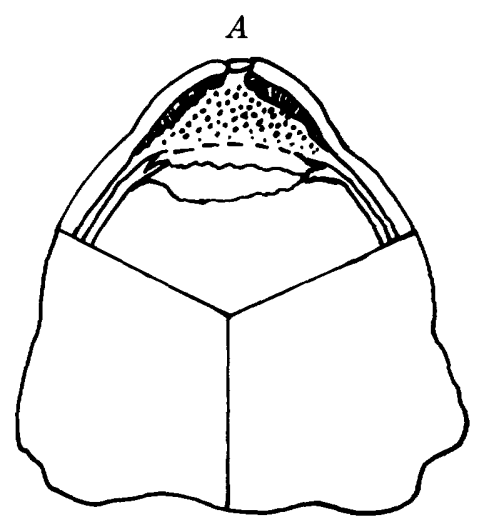

FIGULRE 12. - cf. Pecakipollis sp., ca. $\times 2,000$. A. Sectional view of aperture. endogerminals were not bordered by thickenings. The photographs provided by these workers do not show these details with sufficient clarity to rule out the possibility that some of the species included in the genus Plicapollis may possess circular pores and a thickened endexine adjacent to the endogerminals. Specimens from Mississippi embayment rocks otherwise conforming to the circumscription of Plicapollis all possess definite unequivocal pores. (See pl. 9, figs. 6-24; pl. 10, figs. 1-21.) Most of the specimens from the Mississippi embayment assigned to the genus Plicapollis also show a somewhat pronounced thickening of the endexine adjacent to the endogerminals. Rather than creating a new genus to accommodate these specimens, I have emended the somewhat inadequate original diagnosis to include them.

Plicapollis usitatus, $\mathbf{n}$. sp.

Plate 9, figures 6-14; text figure 13

Holotype. - Sample D3260, slide 2, coordinates $89.8 \times 10.3$, Cusseta Sand Member, Ripley Formation, Alabama, Campanian.

Paratype. - Sample D3260, slide 1, coordinates $110.8 \times 17.7$, Cusseta Sand Member, Ripley Formation, Alabama, Campanian.

Diagnosis. - Shape of pollen grains triangular, with rounded rather than blunt angles. Plicae present, extending from base of germinals to adjacent germinals over the poles. Size $16 \mu-22 \mu$ in equatorial diameter (16 specimens). Wall thin, about $1.5 \mu$ thick in interapertural areas. Ektexine and endexine of about equal thickness and separated by a very narrow interloculum or "Schichtfuge"; ektexine smooth. Exogerminals circular pores, surrounded by ektexinal annuli. Ektexine in apertural areas two layered; outer layer thin and structureless, inner consisting of an elongate baculate layer; bacula longer near exopore, decreasing in length toward the root of the germinal. Vestibulum prominent, roomy, $4 \mu-5 \mu$ deep. Endexine at base of germinals, somewhat annulate, sometimes splitting into several lamellae. Endogerminals larger than exogerminals, circular to oval

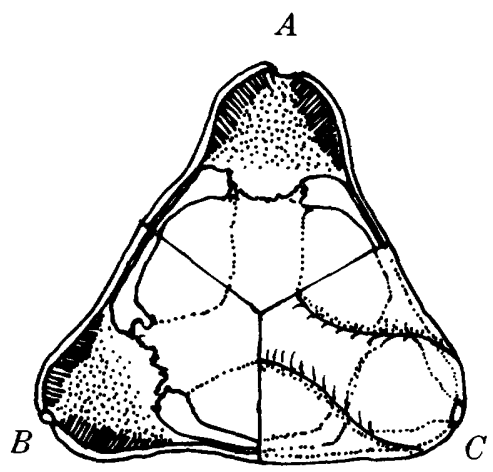

Fl(iuke 13. - Plicapollis usitatus, ca. $\times 2,000 . A, B$, Sectional views of germinals, showing dense baculate layer, narrow interloculum, and annulate endogerminals. $C$, Surface view showing pore and plica. 
with irregular margins.

Stratigraphic distribution. - Cusseta Sand Member of Ripley Formation, Coffee Sand, Coon Creek Tongue of Ripley Formation, and McNairy Sand Member of Ripley Formation.

Plicapollis retusus, n. sp.

Plate 9, figures 15-24; text figure 14

Holotype. - Sample D3412, slide 3, coordinates 112.5 $\times 2.4$, Coffee Sand, Tennessee, Campanian.

Paratype. - Sample D3412, slide 4, coordinates 106.0 19.9, Coffee Sand, Tennessee, Campanian.

Diagnosis. - Pollen grains triangular to slightly concave triangular, with blunt, slightly swollen angles (apertural regions). Plicae prominent, extending from the base of the germinal region to adjacent germinals over the poles. Size $20 \mu-28 \mu$, mostly about $23 \mu$, in equatorial diameter ( 14 specimens). Wall thin, $1.5 \mu-2 \mu$ thick in interapertural areas; ektexine and endexine of about equal thickness, separated in some specimens by a very narrow interloculum; ektexine microverrucate. Exogerminals circular pores surrounded by ektexinal annuli. Ektexine in apertural areas two layered; the outer layer thin and structureless, the inner consisting of somewhat robust radially directed bacula. Vestibulum prominent, roomy, about $5 \mu$ deep. Endexine at base of germinal enlarged, somewhat annulate, commonly split into several lamellae. Endogerminal larger than exogerminal, oval in equatorial direction and with irregular margins.

Remarks. - Pollen of Plicapollis retusus can be distinguished from that of Plicapollis usitatus by its more blunt termination of the germinals, by its slightly larger size, and by its microverrucate, rather than smooth, surface sculpture.

Stratigraphic distribution. - Coffee Sand and Coon Creek Tongue of Ripley Formation.

\section{Plicapollis vacuus, $\mathbf{n}$. sp.}

Plate 10, figures 1-9; text figure 15

Holotype. - Sample D3412, slide 4, coordinates $87.0 \times 3.1$, Coffee Sand, Tennessee, Campanian.

Paratype. - Sample D3412, slide 1, coordinates 78.9 17.7, Coffee Sand, Tennessee, Campanian.

Diagnosis. - Shape of pollen grains triangular with rounded angles (apertural areas); usually straight sided, sometimes slightly concave or convex. Delicate plicae extend from the base of each aperture and join over the poles. Size $16 \mu-23 \mu$ in equatorial diameter, most specimens about $18 \mu$ (based on 16 specimens). Wall about $1 \mu$ thick in interapertural areas, ektexine and endexine of about equal thickness; sometimes a narrow interloculum or "Schichtfuge" can be distinguished between the two wall layers; ektexine smooth to microverrucate. Exogerminal a circular pore in the ektexine. Ektexine in germinal areas generally one layered, structureless, and without thickening. In the in-

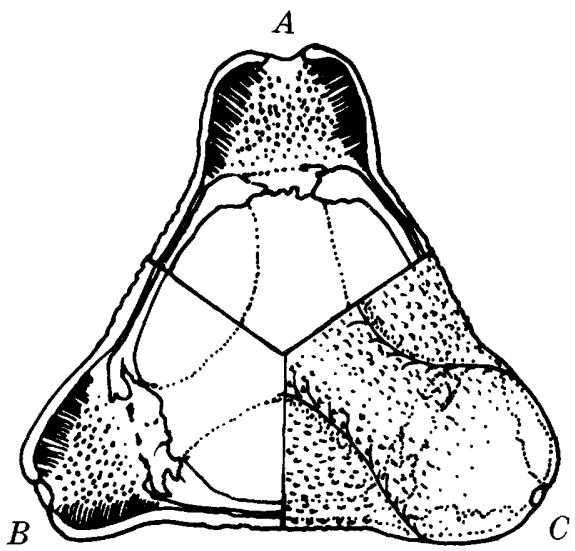

FItilRe 14. - Plicapollis retusus, ca. $\times 2,000 . A, B$, Sectionai views of germinals showing baculate layer, narrow interloculum and annulate endogerminals. $C$, Surface view showing surface sculpture, pore, and plica.

terior of the wall near the pore, scattered short bacula are visible, more abundant near the pore than at the base of the germinals. In occasional specimens bacula are aggregated near the exopore and form a labrum or slight annulus. Vestibulum prominent, about $3 \mu$ deep. Endexine thin, terminating at base of germinal with little or no thickening. Endogerminal oval in equatorial direction with irregular margins.

Remarks. - Pollen assignable to Plicapollis vacuus can be distinguished from that of Plicapollis usitatus and Plicapollis retusus by the virtual absence of aggregates of bacula in the exogerminal, by the possession of thinner walls, and by its generally smaller size.

Stratigraphic distribution. - Coffee Sand and McNairy Sand Member of Ripley Formation.

Plicapollis rusticus, n. sp.

Plate 10, figures 10-21; text figure 16

Holotype. - Sample D3412, slide 4, coordinates 110.9 $\times 9.4$, Coffee Sand, Tennessee, Campanian.

Paratype. - Sample D3412, slide 1, coordinates 108.0 $\times 11.8$, Coffee Sand, Tennessee, Campanian.

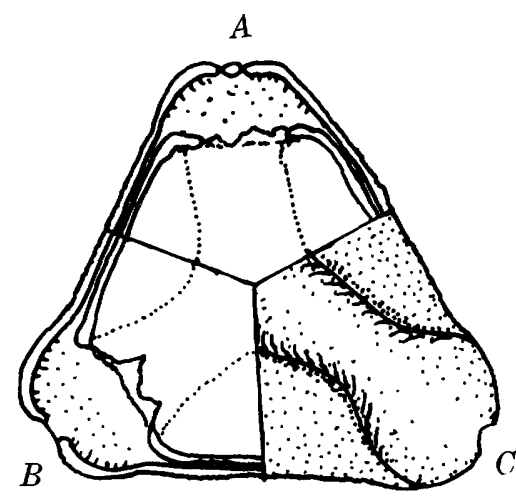

Figure 15. - Plicapollis vacuus, ca. $\times 2,000 . A, B$, Sectional view of apertures, showing only scattered bacula, circular pores, and narrow interloculum. $C$, Surface view showing plica. 
Diagnosis. - Shape of pollen grains triangular to slightly concave triangular in polar view, with blunt corners (apertural areas). Plicae extend from the base of the germinals over the poles to adjacent germinals. Size $22 \mu-29 \mu$ in equatorial diameter (14 specimens). Wall $1.5 \mu-2 \mu$ thick in interapertural areas, ektexine slightly thicker than endexine and separated from it by a narrow interloculum, extexine verrucate with low relief. Exogerminals circular pores surrounded by annulate, twolayered ektexine; outer layer structureless, inner layer of tightly packed, radially directed bacula. Vestibulum prominent, about $4 \mu$ deep. Endexine enlarged, somewhat annulate at the endogerminals, separating into indistinct lamellae. Endogerminal oval in equatorial direction with irregular margins.

Remarks. - Pollen of Plicapollis rusticus is distinguished from that of other species by its prominent verrucate sculpture and its somewhat larger size.

Stratigraphic distribution. - Coffee Sand.

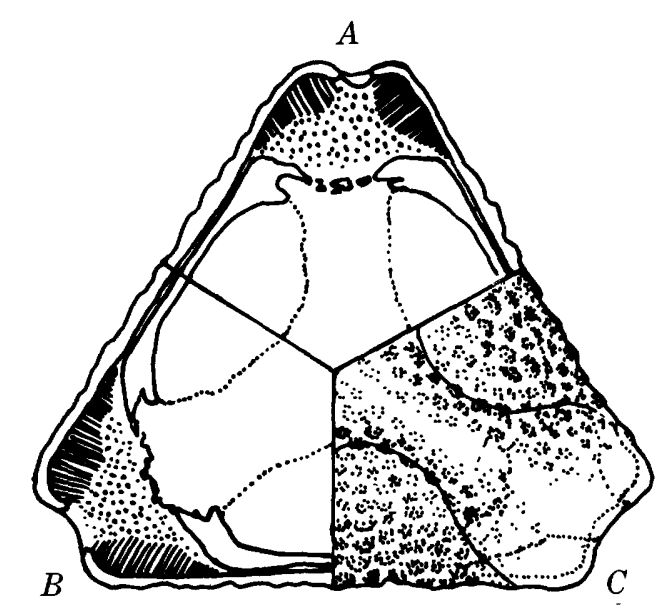

F IGURE 16. - Plicapollis rusticus, ca. $\times 2,000 . A, B$, Sectional views of apertures, showing circular pores, baculate areas, interloculum, and annulate endexine. $C$, Surface view showing sculpture and plica.

\section{Genus POMPECKJOIDAEPOLLENITES Krutzsch, 1967}

Type species. - Pompeckjoidaepollenites subhercynicus (Krutzsch, 1954) Krutzsch, 1967 (in Góczán and others, 1967), Paläontologische Abhandlungen, ser. 8, v. 2 , no. 3 , p. 491 , pl. 13, fig. 25 .

Synonymy. - A guide to the synonymy of the species $P$. subhercynicus is provided by Krutzsch (in Góczán and others, 1967, p. 492).

Diagnosis. - (From Krutzsch, in Góczán and others, 1967) Pollen shallow triangular to oval lens shaped, equatorial contour triangular convex to round. Wall with two distinct principal layers separated by an interloculum. Surface fine to distinctly punctate (LOpattern) with a columella layer as the interior limit of the outer-wall section. Outer wall, in addition, sometimes with structure (baculate, tubulate, and so forth). With three equatorial germinals at the angles.
Exogerminals with annuli, these mostly radial baculate structured. Exopores not vertical slit shaped, but, at most, only vertical oval or, in general, only circular. Endopori connected over the poles by the development of platea, whereby the pole regions sometimes can have endexinous islands. With or without endannuli in the equatorial region (when viewed in optical section). Small to medium sized, rarely large forms.

Remarks. - This genus is listed by Góczán and others (1967) as Pompeckjoidaepollenites (Pflug, 1953) n. emend. W. Kr. However, Pompeckjoidae-pollenites was not listed as a genus by Pflug (1953) but only as a section of the genus Trudopollis. Pollen assignable to this new genus can be distinguished from that now included in Trudopollis by the presence of round to oval exopores rather than vertical slit-shaped germinals and by the presence of fully developed platea.

Pompeckjoidaepollenites aff. P. subhercynicus (Kr., 1954) Kr., 1967 Plate 11, figures 1-8

Remarks. - The lectotype for Trudopollis subhercynicus (now Pompeckjoidaepollenites subhercynicus) is the specimen-plate 4, figure 12, of Potonié (1934). (See Krutzsch, 1961.) The original description of this taxon, in the light of more recent observations and interpretations of the fine structure of Normapolles genera, is somewhat misleading. I have therefore included below a description of the Mississippi embayment specimens that I believe are closely related to Pompeckjoidaepollenites subhercynicus.

Description. - Shape of pollen grains convex triangular to almost circular in polar view, apertural areas slightly protruding. Size $21 \mu-26 \mu$ in equatorial diameter ( 10 specimens). Wall of two principal layers, about $2 \mu$ thick in the interapertural areas, surface smooth, appearing scabrate to microverrucate, owing to the presence of bacula in the interloculum. Ektexine and endexine of about equal thickness in interapertural areas; ektexine thickened and annulate and consisting of two distinct layers at the apertures. Outer ektexine layer structureless, inner layer of radially projecting bacula that appear to fill the vestibula. Exogerminals consist of circular pores opening into a parallel-walled channel. Endexine in the form of three platea separated by a solution meridian over the poles. Individual platea cup shaped and separated from the ektexine by a prominent interloculum, inner layer of ektexine provided with short bacula that project into the interloculum. Platea may become disattached from the ektexine and lie at random in the cell lumen. Outer margins of the endexine thickened, club shaped (in optical section) adjacent to the apertures; the thickened part may extend part way poleward along the inner margins of the platea. Endexine appears to separate into additional lamellae at the apertures.

Stratigraphic distribution. - Reklaw Formation. 


\section{Genus OCULOPOLLIS Pflug, 1953}

Type species - Oculopollis concentus Pflug, 1953, Palaeontographica, v. 95 , ser. B, p. 110 , pl. 19, figs. 45-49.

Diagnosis. - ("New wording" from Góczán and others, 1967.) Central part of pollen grains shallow lens shaped, one hemisphere with a concave and one with a convex surface. The three equatorial germinals located at the angles possess typical, sharply limited oculi in both hemispheres, these oculi strongly influence the shape and contour of the grains, although more so on one hemisphere than on the other. Equatorial contour generally is triangular convex to circular, mostly with interrupted outline. Surface smooth to strongly sculptured, wall sometimes also strongly structured. Exogerminals strong, monannulate, commonly with structure. Exopores in the form of vertical slits, mostly asymmetrical to the equator, pore canal opening outward, strongly constricted toward the inner part. Vestibulum mostly shallow slit shaped; sometimes with interloculum. Endogerminals with only weak thickenings of both outer lamellae of the endexine; endopores small, forming shallow atria with concave borders. The innermost wall lamella forms a wide atrium at the germinal. Small, mostly medium sized, seldom large forms.

Remarks. - The diagnosis of the genus Oculopollis is included here even though specimens of Oculopollis were not observed, because the diagnosis of Pseudoculopollis (Góczán and others, 1967) refers directly to the diagnosis of Oculopollis. Specimens of Pseudoculopollis were found in the Mississippi embayment samples.

The Oculopollis complex includes the genera Bohemiapollis, Oculopollis, Pseudoculopollis and Semioculopollis. Góczán and others (1967) suggested that the genera Oculopollis, Bohemiapollis, and Pseudoculopollis could be combined into one genus with three subgenera and that Semioculopollis species represent a transition group between Oculopollis and Trudopollis.

Genus PSEUDOCULOPOLLIS Góczán, Kr. and Paclt., 1967

Type species. - Pseudoculopollis principalis (Weyl. and Krg.) Krutzsch, 1967 (in Góczán and others, 1967), Paläontologische Abhandlungen, ser. B, v. 2, no. 3, p. 495, pl. 14, figs. 7-13.

Diagnosis. - (From Góczán and others, 1967). As in Oculopollis, but the swellings of the three oculi join over the pole in one hemisphere.

Pseudoculopollis admirabilis, n. sp.

Plate 11, figure 9-18; text figure 17

Holotype. - Sample D3420, slide 5, coordinates 81.5×9.8, McNairy Sand Member, Ripley Formation, Kentucky, Maestrichtian.

Paratype. - Sample D3420, slide 1, coordinates
$102.3 \times 14.4$, McNairy Sand Member, Ripley Formation, Kentucky, Maestrichtian.

Diagnosis. - Shape of pollen grains circular in polar view with three equally spaced strongly protruding germinals with well-developed oculi. Extensions of ocular swellings extend over one pole, oculi not present or poorly developed on other hemisphere. Size $27 \mu-32 \mu$ in equatorial diameter ( 36 specimens). Surface granulate to finely rugulate. Wall consisting of two principal layers, about $1.5 \mu-2 \mu$ thick in the interapertural areas; ektexine about half as thick as endexine. Interloculum absent or very narrow. Exogerminals in the form of vertical slits, slightly subequatorial, slit extending farther toward the pole on the hemisphere bearing fused oculi. Prominent annulate thickenings of the ektexine present adjacent to the exogerminals; annulate area structureless. A prominent, though somewhat narrow, vestibulum is present between the endexine and ektexine in the germinal areas. Endexine with labra or small annuli adjacent to the mesogerminal pore. Mesopores small, somewhat circular and about $4 \mu$ in diameter. An interior lamella of the endexine forms a shallow submesoporal atrium.

Remarks. - Pseudoculopollis admirabilis can be distinguished from $P$. principalis by the finer, less strong rugulate sculpture and by the much better development of the fused oculi on one hemisphere. The species $P$. concentricoides is smooth.

Stratigraphic distribution. - McNairy Sand Member, Ripley Formation.

Pseudoculopollis sp. A

Plate 12, figures 1-6; text figure 18

Remarks. - Only one specimen of this species was observed. It differs from other species of Pseudoculopollis by the presence of arci extending from

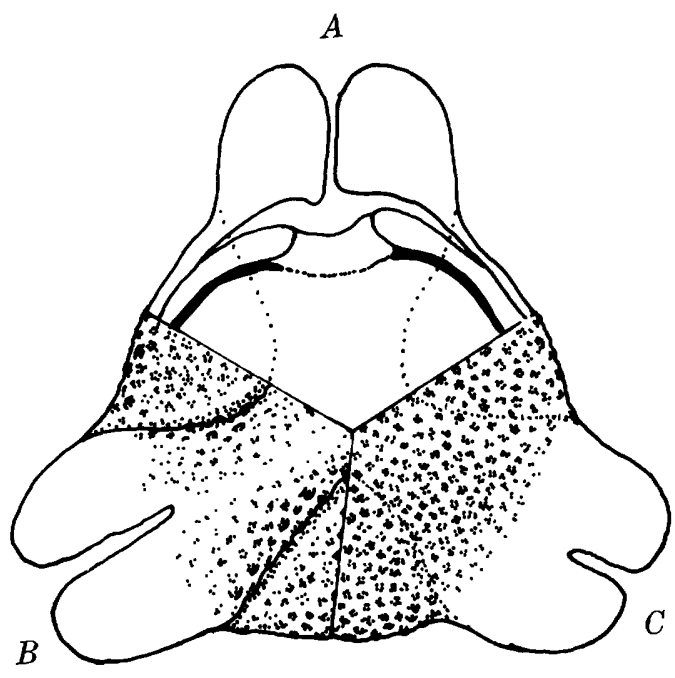

Figure 17. - Pseudoculopollis admirabilis, ca. $\times 2,000$. A, Sectional view of aperture. $B$, Elongate slit-shaped exogerminal and oculus fused over the pole on one side of grain. $C$, Short slit-shaped exogerminal and absence of oculus on obverse side of grain. Surface sculpture shown on $B$ and $C$. 


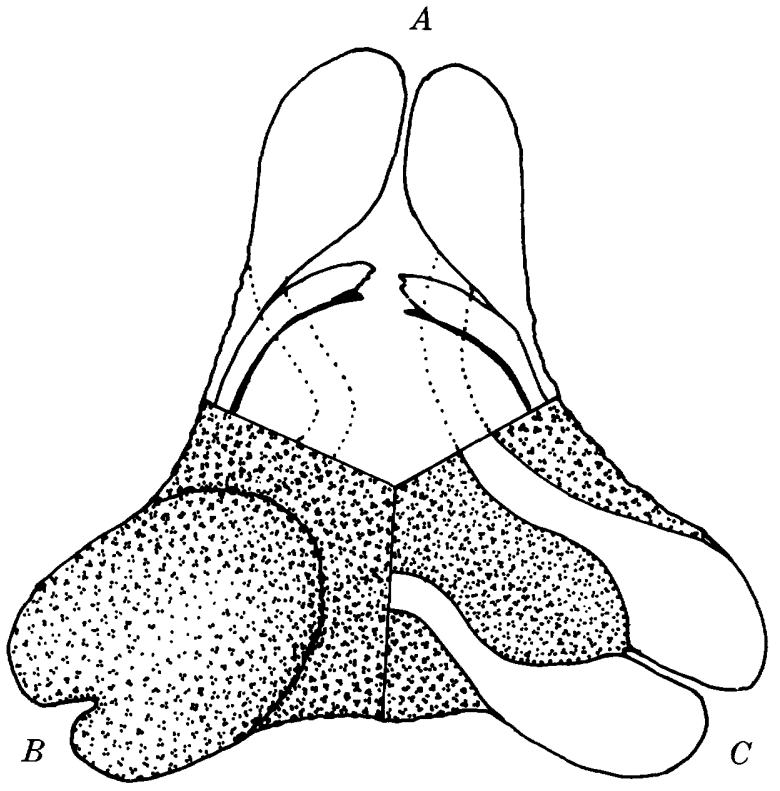

FigURE 18. - Pseudoculopollis sp. A, ca. $\times 2,000 . A$, Sectional view of aperture. $B$, Oculus on one hemisphere. $C$, Absence of oculus in obverse hemisphere. Arci present in this hemisphere only.

the oculi over one hemisphere to adjacent oculi. The specimen observed is $86 \mu$ in equatorial diameter. A very small submesoporal atrium was observed. I consider one specimen inadequate for the erection of a new genus or species and am including a drawing and illustrations to demonstrate an additional variation in the Oculopollis complex.

Stratigraphic distribution. - McNairy Sand Member of Ripley Formation.

Genus SEMIOCULOPOLLIS Góczán, W. Kr. and Paclt., 1967

Type species. - Semioculopollis minutus W. Kr. and Paclt., 1967 (in Góczán and others, 1967), Paläontologische Abhandlungen, ser. B, v. 2, no. 3, p. 503, pl. 16, figs. 13-15.

Diagnosis. - (From Góczán and others, 1967.) Pollen grains shallow lens shaped, equatorial contour weakly convex triangular, whereby the three equatorial germinals enter strongly in the contour. Wall of several layers, with two chief segments, occurrence of these distinctive, often the inner somewhat thicker than the outer. Surface smooth to finely sculptured. Germinal opening assembled somewhat as in Oculopollis, only the enlargement of the oculi is not typical, mostly somewhat strongly developed only on one side; the oculi can, however, be almost absent. Only small to medium-sized forms.

Semioculopollis sp. A

Plate 12, figures 7-13; text figure 19

Description. - Pollen grains circular in polar view with prominent protruding oculi surrounding the germinal apertures. Oculi present on one hemisphere only and do not extend to the pole. Size $23 \mu-25 \mu$ in equatorial

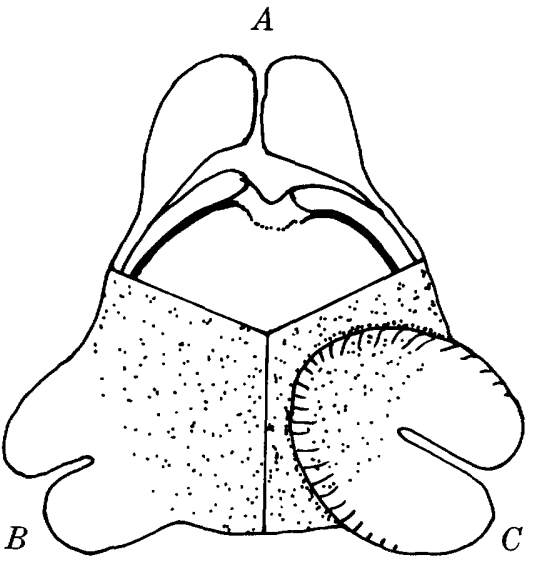

FIGURE 19. - Semioculopollis sp. A., ca. $\times 2,000$. A, Sectional view of aperture. $B$, Short slit-shaped exogerminal on one side of grain. $C$, Oculus and elongate slit-shaped exogerminal on obverse side of grain. Granulate surface sculpture shown on $B$ and $C$.

diameter (three specimens), surface granulate. Wall two layered, ektexine about half the thickness of the endexine in interapertural areas; no interloculum. Exogerminals in the form of vertical slits, slightly subequatorial, slit extending farther toward pole on the hemisphere with oculi. Large annulate thickenings adjacent to exogerminals, about $4 \mu-5 \mu$ high and $4 \mu-5 \mu$ broad on each side of exogerminal, annulate area structureless. A prominent roomy vestibulum is present between the endexine and ektexine. Endexine with slight annuli adjacent to the mesopores. Mesopores small, $2 \mu-3 \mu$ in diameter. Interior lamella of endexine forms a shallow submesoporal atrium.

Remarks. - This species appears to differ from other species of Semioculopollis by the presence of larger, more protruding oculi. Too few specimens were observed to justify the diagnosis and typification of a new species.

Stratigraphic distribution. - Cusseta Sand Member of Ripley Formation and McNairy Sand Member of Ripley Formation.

\section{Genus PSEUDOPLICAPOLLIS Krutzsch, 1967}

Type species. - Pseudoplicapollis palaeocaenicus Krutzsch, 1967 (in Góczán and others, 1967), Paläontologische Abhandlungen, ser. B, v. 2, no. 3 , p. 496, pl. 14, figs $26-31$.

Diagnosis. - (From Krutzsch, in Góczán and others, 1967.) Pollen grains triangular shallow lens shaped, somewhat thickened in the region of the always present plicae. Equatorial contour triangular (with sometimes weakly interrupted sides) to triangular convex with slightly blunted angles. Wall thin, composed of two principal layers, with a ratio of about $1: 1$. Surface smooth to weakly microsculptured. With three equatorial germinals at the angles; exogerminals with annuli, inner with only weak structure, sometimes also appearing smooth but slightly thickened and not elongate. Exopores small, canal index much under 0.3 , vertically 
elongate and often weakly asymmetrical to the equator, opening outward. Sometimes with a roomy vestibulum. Endogerminals not thickened, with equatorial slitshaped opening; the plicae terminating internally with small points - that is, the tips triangular to obtuse triangular in the endopores. No oculi, no interloculum, and so forth. Throughout small to sometimes mediumsized forms.

Remarks. - Krutzsch (in Góczán and others, 1967) erected the genus Pseudoplicapollis to accommodate those pollen grains previously included in the genus Sporopollis. A new generic designation was required because the holotype of the genus Sporopollis is a gleichenoid spore and distinctly different from the pollen grains previously included in the genus. Krutzsch also transferred previously designated Sporopollis species to Pseudoplicapollis, including Pseudoplicapollis pseudosporites (Pflug) Krutzsch, n. comb., and $P$. peneserta (Pflug) Krutzsch, n. comb. He transferred Trudopollis proparvus Pflug, 1953, to Pseudoplicapollis proparvus (Pflug) Krutzsch, n. comb., and named one new species, Pseudoplicapollis palaeocaenicus, and designated it as the type species.

Pseudoplicapollis endocuspis, n. sp.

Plate 13, figures $1-7$; text figure 20

Holotype. - Sample D3265, slide 1, coordinates 101.2 $\times 6.7$, Eutaw Formation, Georgia, Coniacian.

Paratype. - Sample D3265, slide 3, coordinates 107.5 $\times 9.2$, Eutaw Formation, Georgia, Coniacian.

Diagnosis. - Shape of pollen grains slightly convex triangular with somewhat acute angles. Size $16 \mu-22 \mu$ in equatorial diameter, (11 specimens) slightly inflated delicate plicae extend from each angle (germinal) over the poles to adjacent germinals. Wall two layered, thin, less than $1 \mu$ thick in interapertural areas, about $1.5 \mu$ thick at the apertures. Ektexine smooth, enlarged at apertures in the form of a slight labrum, two layered at aperture, outer layer structureless, inner layer consisting of very short radially directed bacula. Exogerminals short, vertical slit shaped. Vestibulum narrow, inverted $V$-shaped. Endexine thin, provided with acute angled points or flaps in the germinal area as extensions of the plicae. Endogerminal elongate equatorially between the pointed endexinal extensions.

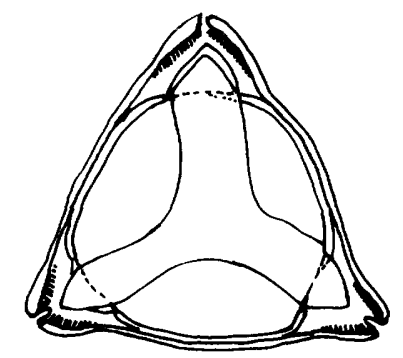

Figure 20. - Pseudoplicapollis endocuspis, ca. $\times 2,000$.
Remarks. - In general appearance this species is similar to Pseudoplicapollis palaeocaenicus. The latter species, however has a finely punctate surface sculpture and coarser plicae.

Stratigraphic distribution. - Eutaw Formation, Coffee Sand, Coon Creek Tongue of Ripley Formation, McNairy Sand Member of Ripley Formation, McNairy Sand, Clayton Formation, and Porters Creek Clay. Single grains were observed in the Wilcox and Tallahatta Formations, but these may have been redeposited.

Pseudoplicapollis serenus, n. sp.

Plate 13, figures $8-12$; text figure 21

Holotype. - Sample D3412, slide 2, coordinates 84.7 $\times 13.0$, Coffee Sand, Tennessee, Campanian.

Paratype. - Sample D3412, slide 4, coordinates $87.7 \times 6.5$, Coffee Sand, Tennessee, Campanian.

Diagnosis. - Shape of pollen grains slightly convex triangular with blunt or obtuse angles. Germinals slightly inflated, interrupting the equatorial contour. Size $13.5 \mu-19 \mu$ in equatorial diameter (17 specimens). Delicate, slightly inflated plicae extend from apertural regions over the poles. Wall two layered, about $1 \mu$ thick in interapertural areas and about $2 \mu$ thick at apertures. Ektexine and endexine of about equal thickness. Ektexine smooth, inflated at apertures in the form of a thickened labrum or annulus; two layered near apertures; outer layer structureless, inner layer of short, radially directed bacula. Exogerminals short, vertical slit shaped. Endexine provided with pointed obtuse angled flaps in the germinal areas that are extensions of the endexinal plicae. Vestibulum prominent, in polar view appearing as two somewhat oval chambers, one on each side of the plica extension. Endogerminals wide, horizontal slit shaped, located between the pointed extremities of the flaps.

Remarks. - This species is distinguishable from other species of Pseudoplicapollis by its obtuse, blunt germinal regions and by the double oval shape of its vestibulum. It is distinguished from Minorpollis by the presence of distinct plicae.

Stratigraphic distribution. - Coffee Sand.

Pseudoplicapollis sp. A

Plate 13, figures 13-17; text figure 22

Description. - Pollen grains triangular in polar view

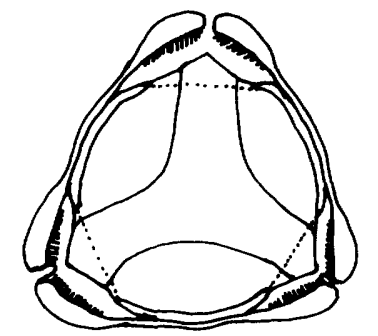

FIGURE 21. - Pseudoplicapollis serenus, ca. $\times 2,000$. 


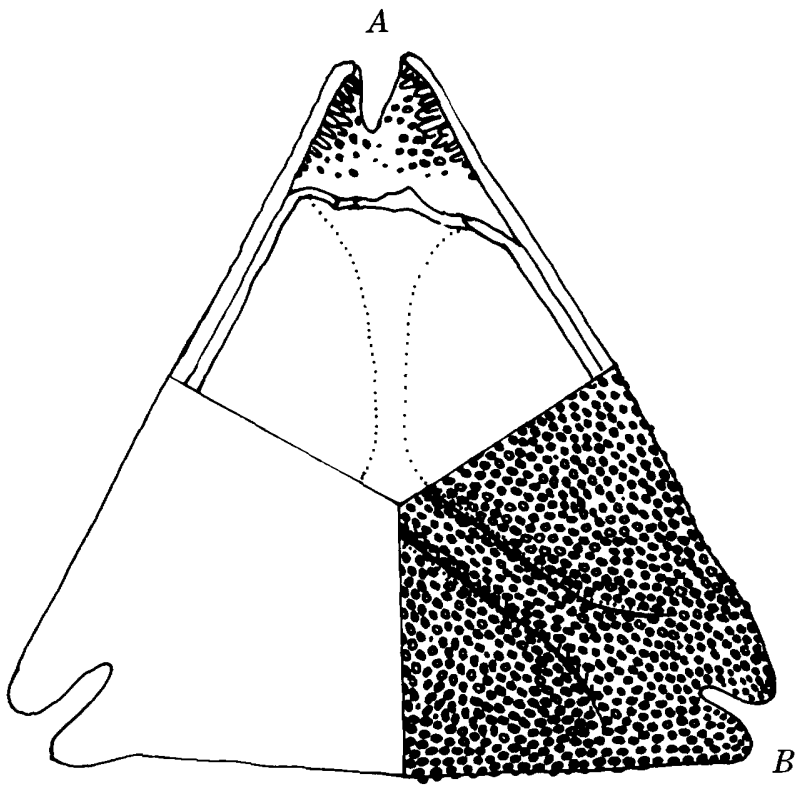

Figure 22. - Pseudoplicapollis sp. A., ca. $\times 2,000 . A$, Sectional view of aperture showing scattered robust bacula, and endogerminal. $B$, Surface view showing delicate plica and microverrucate surface sculpture.

with almost straight sides. Size $25 \mu-36 \mu$ in equatorial diameter (eight specimens). Very slightly inflated delicate narrow plicae extend from each angle over the poles. Wall two layered, about $1 \mu$ thick in interapertural areas, $2 \mu$ to $3 \mu$ thick at the apertures. Surface microverrucate to verrucate with low relief. Ektexine inflated at apertures to form a slight labrum; outer layer thin, structureless, inner layer of short robust loosely arranged bacula. Exogerminals equatorial, vertical slit shaped. Vestibulum narrow, poorly defined. Endexine thin, with somewhat rounded slightly elevated terminations in the vestibulum as extensions of the plicae. Endogerminals elongate equatorially with irregular margins.

Remarks. - This species can be distinguished from other species of Pseudoplicapollis by its larger size. Too few specimens were found to allow for naming this taxon.

Stratigraphic distribution. - Nanafalia and Wilcox Formations.

Genus PSEUdOVACUOPOLLIS Krutzsch and Pacltová, 1967

Type species. - Pseudovacuopollis intraconcavus Krutzsch (in Góczán and others, 1967), Paläontologische Abhandlungen, ser. B, v. 2, no. 3, p. 499, pl. 15, figs. 1-5.

Diagnosis. - (From Krutzsch and Pacltová, in Góczán and others, 1967.) Pollen grains triangular shallow lens shaped to triangular concave, with a tendency to a constriction of the equatorial contour in the interapertural areas. Germinals equatorial at the angles. Wall of several layers, variously thick, the proportion between the several layers varies among the different formspecies. The outer principal wall layer [ektexine] sometimes has an inner thickening in the interapertural areas. Surface smooth to weakly and shallowly verrucate; sometimes with columella layer as an inner limit to the outer wall complex. With or without an interloculum. Inner wall complex possessing several smooth lamellae; often very thin. Exogerminals with structured annuli; monannulate or polyannulate. Exopores vertical slit shaped to oval. Endogerminals with several stepped, sometimes deeply sunken, atria, the almost platealike solution areas sometimes reach near the polar regions. Irregular endannuli or exfoliation of the lamellae sometimes weakly developed at the sides of the atria. Inner wall layers only seldom clearly developed, most often absent. No plicae, oculi, arci, and so forth. Forms mostly small to medium sized.

Remarks. - The characteristics of this genus are very similar to those of Vacuopollis; indeed, Krutzsch and Pacltová (in Góczán and others, 1967) suggested that both could rank as subformgenera of the same genus. They distinguish the two genera principally by the tendency toward development of a constriction in the interapertural areas and a greater differentiation of the endexine in Pseudovacuopollis.

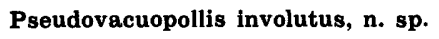

Pseudovacuopollis involutus, n. sp.

Plate 14, figures 1-12; text figure 23

Holotype. - Sample D3416, slide 2, coordinates $92.9 \times 6.4$, McNairy Sand, Missouri, Maestrichtian.

Paratype. - Sample D3416, slide 2, coordinates $104.7 \times 10.7$, McNairy Sand, Missouri, Maestrichtian.

Diagnosis. - Shape of pollen grains slightly concave triangular to extreme concave triangular in polar view; a constriction in the interapertural areas commonly present. Size $15 \mu-23 \mu$ in equatorial diameter (17 specimens). Wall of two principal layers, $1 \mu-1.5 \mu$ thick in the interapertural areas. Surface smooth. Ektexine in interapertural areas sometimes conspicuously thickened internally, becoming less so at bases of germinal areas. Ektexine thickened and annulate, consisting of two layers adjacent to the vertical slit-shaped exogerminal; outer layer structureless, inner layer consisting of com-

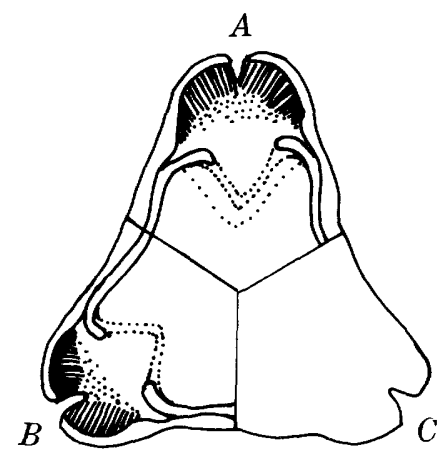

Firure 23. - Pseudovacuopollis involutus, ca. $\times 2,000 . A, B$, Sectional views of apertures showing baculate layer, $V$-shaped endogerminals, and interapertural ektexinal thickening. $C$, Surface view. 
pact, radially directed bacula. Endexine thin, less than $1 \mu$ thick with weakly developed endannuli adjacent to the atria. Inner margins of atria $V$-shaped in polar view. Inner layers of endexine poorly developed, secondary atria only occasionally visible.

Remarks. - This species differs from Pseudovacuopollis intraconcavus Krutzsch, 1967, and $P$. triangulatus (Ross) Krutzsch, 1967, by possessing a smooth surface and poorly developed accessory atria.

Stratigraphic distribution. - Coffee Sand, Coon Creek Tongue of Ripley Formation, McNairy Sand Member of Ripley Formation, and McNairy Sand.

Genus THOMSONIPOLLIS Krutzsch, 1960, non Elsik, 1968

Type species. - Thomsonipolis magnificus (Thoms. and Pflug) Krutzsch, 1960a, Freiberger Forschungshefte, v. C86, p. 58. Holotype, Th. and Pf., 1953, pl. 9, fig. 112.

Diagnosis. - (From Krutzsch, 1960a.) Pollen grains $25 \mu-50 \mu$ in diameter possessing three germinals that are complex, nonprotruding, and equatorially or slightly subequatorially arranged. Equatorial contour round to convex triangular and (in uncrumpled condition) oval to spherical shaped. The polar axis sometimes can be considerably shorter than the equatorial axis producing a lens-shaped pollen grain. Wall always many layered with three lamella complexes. The outermost bears mostly a strong baculalike to mushroom-shaped sculpturing that only seldom reveals the underlying exolamella. The middle wall complex is developed as many layered, unstructured, hyaline smooth lamellae oppressae (primarily in the intergerminal areas) and as lamellae conspicuae (at the germinals). Innermost complex unstructured, thin, yet with a refractive index different from the middle layer, and thereby easily separable from it. No interlocula, only seldom are "Schichtfuge" developed between the three wall complexes (these as a result of corrosion?). Germinal opening: "Exopore" equatorial slit shaped, oval or circular, about $5 \mu$ in diameter. "Mesopore" arises from the outer lamellae of the middle wall complex, these are reflexed inward, and undergo differentiation in the form of thickening, annulus formation, exfoliation, and so forth. The innermost lamelae of the middle wall complex are likewise variously strongly differentiated and form several roomy oval to circular "atria," just as do - only with a regular boundary - the third inner wall complex (="endopores" - Atrium).

Thomsonipollis magnificus (Th. and Pf. 1953) Krutzsch, 1960a Plate 14, figures $13-20$

Synonymy. - See Krutzsch, 1960a.

Diagnosis. - ("New wording" from Krutzsch, 1960a.) A form species of Thomsonipollis with thick to very thick wall, inclusive of the structure layers of the extragerminal about $2 \mu-4 \mu$ thick; considerable lamellae differentiation in the region of the middle wall complex, whereby often three lamella groups are recognizable, their thickenings, exfoliations, and so forth, swell toward the germinals. Size $25 \mu-50 \mu$, mostly $30 \mu-35 \mu$.

Stratigraphic distribution. - Naborton, Naheola, Nanafalia, Wilcox, Pendleton (Andersen, 1960), Hatchetigbee, and Reklaw Formations.

Thomsonipollis magnificoides Krutzsch, 1960a

Plate 15 , figures $1-8$

Diagnosis. - (From Krutzsch, 1960a.) A form species of Thomsonipollis with a thinner and finer wall, inclusive of the structure layers of the extragerminals, only $1.5 \mu-2 \mu$ thick. Innermost lamellae of the middle wall layer interrupted only in form of steps; exfoliation, thickening, and so forth, almost completely lacking. "Mesopore" relatively broad. Size $27 \mu-40 \mu$, mostly $30 \mu-33 \mu$.

Remarks. - At the extremes, Thomsonipollis magnificus and Thomsonipollis magnificoides can be distinguished readily. However, specimens with intermediate wall thicknesses are difficult to place in the appropriate species.

Stratigraphic distribution. - Same as for Thomsonipollis magnificus.

Thomsonipollis aff. T. magnificoides

Plate 15, figures 9-20; text figure 24

Description. - Shape of pollen grains almost circular in polar view, inflated lens shaped, almost spherical. Size $16 \mu-27 \mu$ in equatorial diameter, average $22 \mu$ (15 specimens). Wall of two principal layers about $1.5 \mu$ thick in interapertural areas, ektexine and endexine of about equal thickness. Ektexine with coarsely clavate-baculate sculpture, clavae not tightly spaced, endexine hyaline, structureless. Triporate, pores equatorial or nearly so. Endexine (middle layer of Krutzsch) thinning adjacent to exopore, then the upper part of the endexine turns inward forming a short channel. Inner layer (of Krutzsch) visible only as a hyaline refractive line below the germinals.

Remarks. - These specimens differ from Thomsonipollis magnificus by their smaller size, more delicate

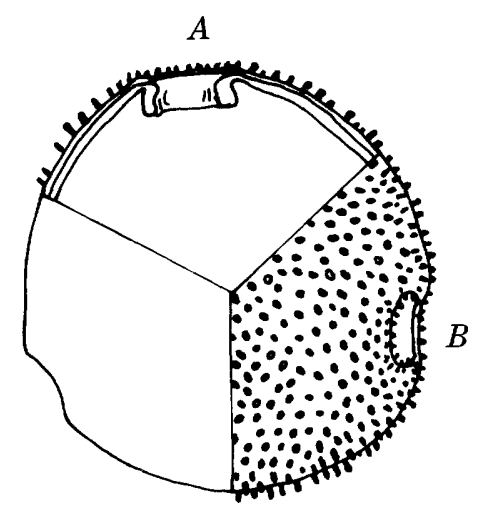

FIgURE 24. - Thomsonipollis aff. T. magnificoides, ca. $\times 2,000$. A, Sectional view of aperture showing reflexed endexine and thin wall. $B$, Surface view showing circular exorgerminal, and scattered ektexinal bacula and clavae. 
and thin walls, more widely spaced sculpturing, and less structured germinals. They differ from $T$. magnificoides principally by their smaller size and more widely spaced sculpturing. Even though no observed specimen was as large as the average size $T$. magnificoides and the bacula and clavae are more scattered, I am reluctant to erect a new species on the basis of these minor characteristics.

Stratigraphic distribution. - Owl Creek Formation, Clayton Formation, one specimen observed in a sample from the Porters Creek Clay. The stratigraphic range of this form is significantly different from that of Thomsonipollis magnificoides.

Thomsonipollis expolitus, n. sp.

Plate 16, figures 1-12; text figure 25

Holotype. - Sample D3410-C, slide 4, coordinates 74.5 $\times 11.5$, Owl Creek Formation, Mississippi, Maestrichtian.

Paratype. - Sample D3410-C, slide 1, coordinates 104.6×21.4, Owl Creek Formation, Mississippi, Maestrichtian.

Diagnosis. - Pollen grains almost circular in polar view; germinals usually not protruding. Size $16 \mu-24 \mu$ in equatorial diameter (18 specimens). Wall of two principal layers about $1.5 \mu$ thick. Ektexine and endexine of about equal thickness. Surface smooth to weakly microscabrate. Exogerminals circular pores. Endexine hyaline, structureless, thinning adjacent to exopore, then the upper part of endexine turns inward forming a prominent annulus with somewhat irregular inner margin. Endogerminal of approximately the same size as exogerminal. Inner wall layer (of Krutzsch) visible only as a refractive line below the germinals.

Remarks. - This species is somewhat similar to Thomsonipollis gracilis Krutzsch and Lenk, 1967 (in Góczán and others, 1967), except that the latter has a much more flexible wall and less pronounced infolding of the endexine adjacent to the germinal openings. (Holotype: plate 4 explanation, figs. $13 a, b$, in Kunert and Lenk, 1964, p. 412).

Stratigraphic distribution. - Owl Creek Formation.

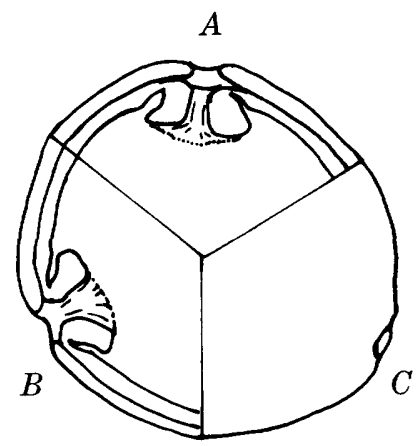

FIGURE 25. - Thomsonipollis expolitus, ca. $\times 2,000 . A, B$, Sectional views of apertures showing the relatively thick wall and the reflexed inward enlargement of the endexine at the apertures. $C$, Surface view.
Genus TRUDOPOLLIS Pflug, 1953, emend. Krutzsch, 1967

Extratriporopollenites pertrudens Pf, 1953 (in Thoms. and Pflug, 1953) p. 74, pl. 6, fig. 74 (and other figures).

Trudopollis pertrudens (Pf.) Pflug, 1953, p. 98, pl. 22, figs. 12, 18.

Trudopollis pertrudens (Pf.) Pflug, 1953, Lectotype designated by Krutzsch, 1967 (in Góczán and others, 1967), same specimen as in Thoms. and Pf., 1953, pl. 6, fig. 74.

Type species. - Trudopollis pertrudens (Pflug) Pflug, 1953.

Diagnosis. - (From Krutzsch, in Góczán and others, 1967.) Pollen grains shallow to oval lens shaped; equatorial contour triangular to convex triangular or circular. Wall several layered, always two principal layers recognizable, often with "Schichtfuge" or interloculum. Surface always more or less clearly fine sculptured. Wall also sometimes with columella layer or other structure. With three equatorial germinals located at the angles. Exogerminals with tumescens, annulus, or similar thickening that sometimes strongly affects the contour; the inner part almost always with structure (radial baculate, punctate, and so forth), structured part either free or compact and terminates in a variously large vestibulum, not covered by a wall layer. Pore canal index less than 0.3. Outer part of exopores vertical slit shaped, opening nearly symmetrical with the equator. Endopores sometimes with weak thickenings around the atrium; atria of different shapes and variously deep.

No solution channels over the poles; sometimes also the endopores lie asymmetrical to the equatorial oculi that occasionally are present as attachments (accessory developments).

Remarks. - Krutzsch (in Góczán and others, 1967) emended the genus Trudopollis to exclude those species with an endexinal solution channel over the poles (those species with platea) and possessing circular or oval exogerminals (rather than vertical slit-shaped exogerminals). The excluded species were placed in the genus Pompeckjoidaepollenites. Trudopollis variabilis, $\mathbf{n}$. sp.

Plate 16, figures 13-22; text figure 26

Holotype. - Sample D3412, slide 2, coordinates 109.7 $\times 14.1$, Coffee Sand, Tennessee, Campanian.

Paratype. - Sample D3412, slide 2, coordinates $99.5 \times 14.8$, Coffee Sand, Tennessee, Campanian.

Diagnosis. - Shape of pollen grains triangular to convex triangular or circular with protruding equatorial germinals. Size $22 \mu-29 \mu$ in equatorial diameter (20 specimens). Wall two layered, about $1.5 \mu$ thick, no interloculum observed; ektexine and endexine of about equal thickness. Ektexine verrucate usually with low relief; in some specimens verrucae larger in the apertural regions. In apertural areas, ektexine greatly thickened, annulate, indistinctly layered, the outer layer structureless, the inner with diffuse structure consisting of 


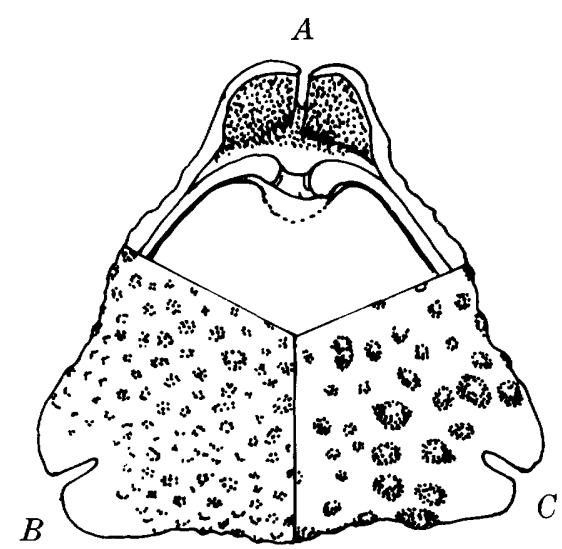

FiguRE 26. - Trudopollis variabilis, ca. $\times 2,000 . A$, Sectional view of aperture. $B$, Surface view showing verrucae. $C$, Surface view showing more robust verrucae present on some specimens.

tightly packed radially directed rodlets or bacula whose free ends are usually clearly visible in the vestibulum. Vestibulum shallow. Exogerminal vertical slit shaped. Mesogerminal a more or less circular pore. Endexine in pore area with labra or endannulus. Inner layer of endexine forms a shallow submesoporal atrium.

Remarks. - Pollen grains of this species are somewhat similar to those described as Trudopollis acinosus by Gray and Groot (1966), except that in their specimens they observed a distinct interloculum and an ektexine about twice as thick as the endexine. Furthermore, they reported no endannulus.

Pollen grains of Trudopollis meekeri Newman (1965) also bear some similarity to $T$. variabilis. However. in $T$. meekeri an interloculum is present, and the endexine is distinctly thinner than the ektexine. In $T$. variabilis an interloculum is lacking, and the ektexine and endexine are of about the same thickness.

Specimens of Trudopollis from the Mississippi embayment are difficult to compare with European forms for the following reasons: About 80 species have been reported; many of the early descriptions are inadequate; the photographs do not show clearly the morphological details required for species identification. None of the species described by Pflug (1953) and Thomson and Pflug (1953) possess a verrucate surface. However, some of the species described as having a fossulate surface sculpture may be irregularly verrucate.

Stratigraphic distribution. - Cusseta Sand Member of Ripley Formation, Coffee Sand, Coon Creek Tongue of Ripley Formation.

Trudopollis plenus, $n$. sp.

Plate 17, figures 1-9; text figure 27

Holotype. - Sample D3138, slide 4, coordinates 113.6×10.0, Naheola Formation, Alabama, Paleocene.

Paratype. - Sample D3138, slide 1, coordinates 91.3×16.7, Naheola Formation, Alabama, Paleocene.

Diagnosis. - Shape of pollen grains convex triangular

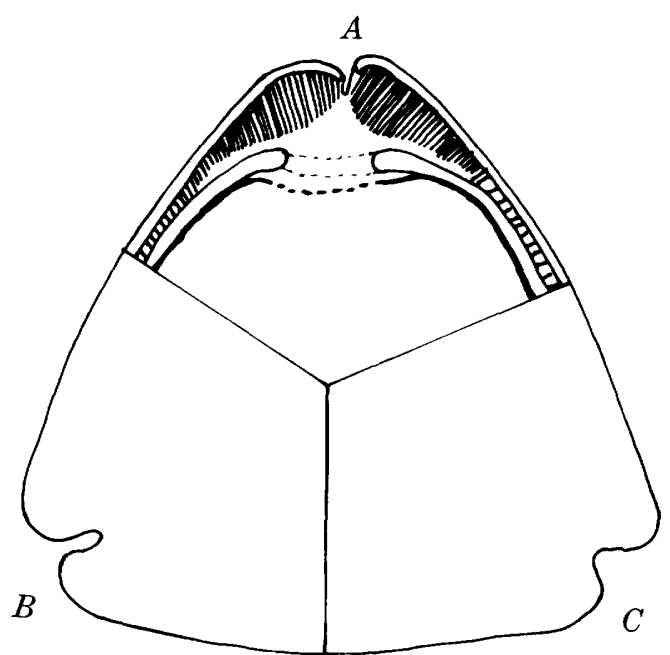

FIGURE 27. - Trudopollis plenus, ca. $\times 2,000 . A$, Sectional view of aperture showing the endogerminal and the baculate layer of exogerminal region extending into the well-developed interloculum. $B, C$, Surface views.

to almost circular in polar view, with only slightly protruding equatorial germinal areas. Size $22 \mu-31 \mu$ in equatorial diameter (based on 21 specimens). Wall of two principal layers $1.5 \mu$ thick in the interapertural areas. Ektexine and endexine of about equal thickness and separated by a prominent interloculum. Ektexine two layered, the outer surface smooth and structureless, the inner composed of short bacula which extend across the interloculum. Baculate layer provides the appearance of a scabrate or microverrucate surface, although the outer surface is smooth. Faint plicae visible on some specimens. Ektexine thickened, annulate near apertures; bacula much elongated in this area, tightly packed and projecting radially with somewhat free ends in the vestibulum. Exogerminals consist of short, meridionally directed equatorial or slightly subequatorial slits. Endexine with a labrum adjacent to the mesogerminal. Mesogerminal somewhat circular, larger than exogerminal; vestibulum very narrow. Inner lamella of endexine separates near mesogerminal and forms an atriate endogerminal whose margins are irregular and appear granulate.

Remarks. - Some specimens have a torn or somewhat eroded incidence or solution notch, but most specimens do not show this.

Stratigraphic distribution. - Naborton and Naheola Formations.

Trudopollis ef. T. artifex Weyl. and Krg., 1953

Plate 17, figures 18-20; text figure 28

Diagnosis. - (From Weyland and Krieger, 1953.) About $25 \mu$. Contour rigid triangular. Free lamella complex strong. Weak oculus. Cubiculum with nearly circular cross section, almost fully closed to the annulus. Strong endexine. The clear annulus intimus is here characteristic. No solution meridian. Intrabaculate 


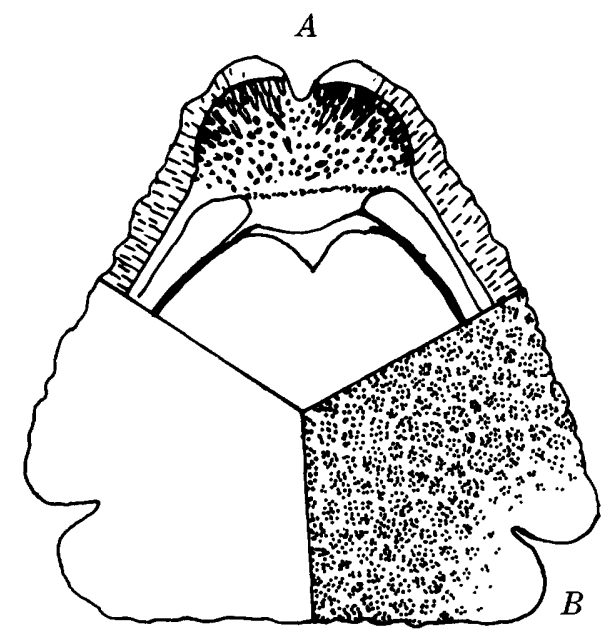

FIGURE 28. - Trudopollis cf. T, artifex, ca. $\times 2,000 . A$, Sectional view of aperture showing short bacula, radial structure of ektexine, interloculum, and endogerminal. $B$, Surface view showing sculpture.

structure in the ektexine.

Description. - (Mississippi embayment specimens) Shape of pollen grains rigid triangular in polar view with rounded apertural areas. Size $24 \mu-28 \mu$ in equatorial diameter (three specimens). Wall of two principal layers, separated by a prominent interloculum; wall $3 \mu-4 \mu$ thick; ektexine and endexine of about equal thickness. Surface irregularly fossulate with low relief. Ektexine thinner in apertural areas than in interapertural areas; with prominent radial structure. Exogerminal meridionally slit shaped, the lips not tightly appressed. Exogerminal opening into a large cubiculum; short bacula project inward throughout roomy cubiculum. Endexine with definite labra adjacent to mesogerminal. Inner lamella of endexine forms a short $V$-shaped notch. Atria not prominent if present.

Remarks. - Trudopollis artifex differs slightly from the Mississippi embayment specimens by possessing a slight oculus and a tightly closed cubiculum. However, our specimens seem to conform otherwise to the circumscription and illustration of Trudopollis artifex.

Stratigraphic distribution. - Coon Creek Tongue of Ripley Formation.

\section{Trudopollis sp. A}

Plate 17, figures $10-12$; text figure 29

Description. - Shape of pollen grains triangular to slightly concave triangular in polar view. Size $22 \mu-23 \mu$ in equatorial diameter (two specimens). Surface smooth. Wall consists of two principal layers, about $1.5 \mu$ thick in the interapertural areas. Endexine about twice as thick as ektexine except in apertural areas. No interloculum. Ektexine in apertural areas two layered, the outer layer structureless and externally smooth, the inner consisting of very tightly packed radially directed bacula whose free ends are visible in the prominent vestibulum. Exogerminals equatorial, meridionally slit shaped. Endex-

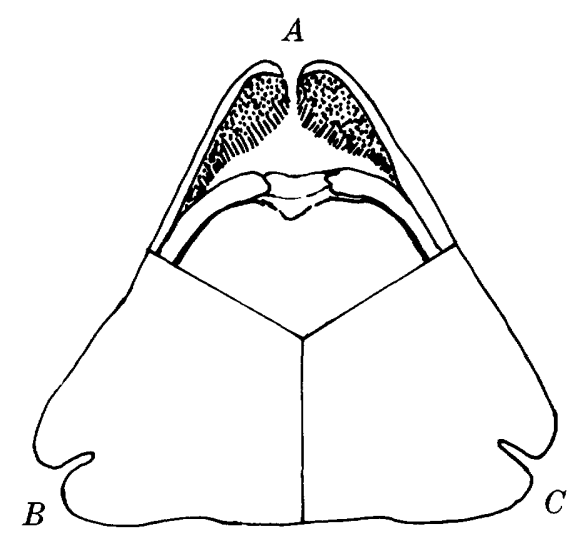

FIGURE 29. - Trudopollıs sp. A, ca. $\times 2,000 . A$, Sectional view of aperture. $B, C$, Surface views.

ine with slight labrum adjacent to the mesopore, mesopore somewhat circular, larger than exogerminal; inner lamella of endexine forming a very narrow submesogerminal atrium.

Remarks. - Somewhat similar to Trudopollis rector Pflug, 1953, but without interloculum, and to Trudopollis nonperfectus (Pflug, in Thoms. and Pf., 1953) but with apparently thicker endexine.

Stratigraphic destribution. - Coffee Sand.

Trudopollis sp. B

Plate 17, figures 13-14; text figure 30

Description. - Shape of pollen grains convex triangular to triangular in polar view. Size $25 \mu-29 \mu$ in equatorial diameter (four specimens). Wall of two principal layers separated by a very narrow "Schichtfuge", wall $1 \mu-1.5 \mu$ thick in interapertural areas. Endexine and ektexine of about equal thickness. Surface scabrate to microverrucate with low relief. Exogerminals equatorial, meridionally slit shaped. Ektexine in apertural areas enlarged, annulate, apparently structureless; annulus

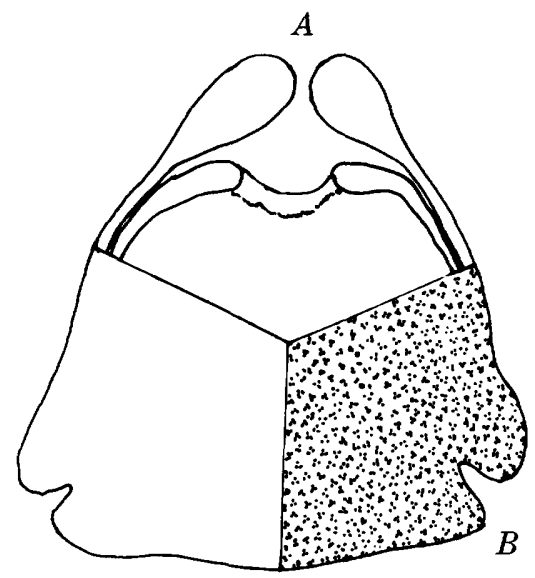

Figure 30. - Trudopollis sp. B, ca. $\times 2,000$. A, Sectional view of aperture showing apparently structureless ektexinal annulus, narrow interloculum, and slightly enlarged endexine at margin of the endogerminal. $B$, Surface view showing scabrate-microverrucate sculpture. 
tear shaped with rounded contour in the roof of the vestibulum. Vestibulurn prominent. Endexine with labra adjacent to the mesogerminal. Inner lamella of endexine does not form a recognizable inner atrium. A semicircular notch present below the mesogerminal.

Remarks. - Trudopollis sp. B can be distinguished from $T$. variabilis by its slightly thinner wall, the teardrop-shaped structureless annulus in contrast to the larger, more angular annulus of $T$. variabilis and by the much finer surface sculpture.

Stratigraphic distribution. - Naborton Formation.

Trudopollis sp. C

Plate 17, figures 15-17; text figure 31

Description. - Shape of pollen grains triangular to slightly convex triangular in polar view; germinal areas rounded and slightly protruding. Size $31 \mu$ in equatorial diameter (one specimen). Wall of two principal layers separated by a narrow "Schichtfuge." Wall about $2 \mu$ thick in interapertural areas. Endexine slightly thicker than ektexine. Surface scabrate to densely microverrucate with low relief. Exogerminals equatorial, meridionally narrow slit shaped. Ektexine in apertural areas enlarged, annulate, structureless except for innermost part. Inner part of annulus studded with short pointed bacula whose free ends project into the vestibulum. Endexine with slight labra adjacent to the mesogerminal. Endexine of two distinct lamellae. No obvious atrium observed. A semicircular notch is present below the mesogerminal.

Remarks: - Very similar to sp. B except for its larger size; has more robust annuli, more dense and smaller verrucae, and a recognizable definite two-layered endexine.

Stratigraphic distribution. - Pendleton Formation (Andersen, 1960).

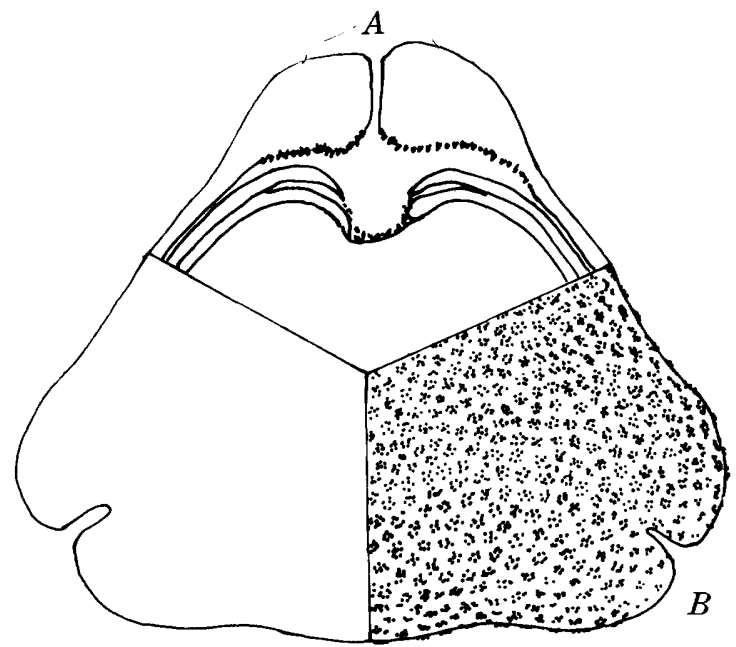

FIGURE 31. - Trudopollis sp. C, ca. $\times 2,000$. A, Sectional view ot aperture showing inner part of ektexinal annulus with short bacula, narrow interloculum, and the two lamellae of the endexine. $B$, Surface view showing sculpture.
Genus VACUOPOLLIS Pflug, 1953

Type species. - Vacuopollis percentus Pf., 1953, Palaeontographica, ser. B., v. 95, nos. 4-6, p. 104, pl. 20, figs. 24-26.

Diagnosis. - ("New wording" from Góczán and others, 1967.) Pollen grains triangular shallow lens shaped, seldom triplanoid. Equatorial contour extends from weakly convex triangular with slightly interrupted or uninterrupted sides to strongly triangular to weakly triangular concave. Corners sometimes strongly rounded. Wall with two principal layers, thickness of the entire wall and thickness of the individual wall segments very different. Surface smooth to weakly microsculptured. Mostly without structure in the extragerminal region. With three equatorial germinals located at the angles. Exogerminals with annuli, sometime labroid, seldom strongly thickened, often with prominent baculate structure layer (= conclave pro parte, according to Pflug, 1953); exopore vertical slit shaped terminating outward, more or less symmetrical with the equator. Pore canal index less than 0.3. Mostly with a wide vestibulum. Endogerminal not thickened, at the pore endexine somewhat split into lamellae; therefore, two to three, seldom more, stepped atria in succession and with shallow concave, semicircular or seldom deeper margins. No oculi; seldom an interloculum indicated. No plicae or arci. Forms small to medium sized.

Vacuopollis munitus, n. sp.

Plate 18, figures 1-19; text figure 32

Holotype. - Sample D3416, slide 1, coordinates $74.1 \times 11.8$, McNairy Sand, Missouri, Maestrichtian.

Paratype. - Sample D3416, slide 1 coordinates 82.7×18.7, McNairy Sand, Missouri, Maestrichtian.

Diagnosis. - Shape of pollen triangular to slightly

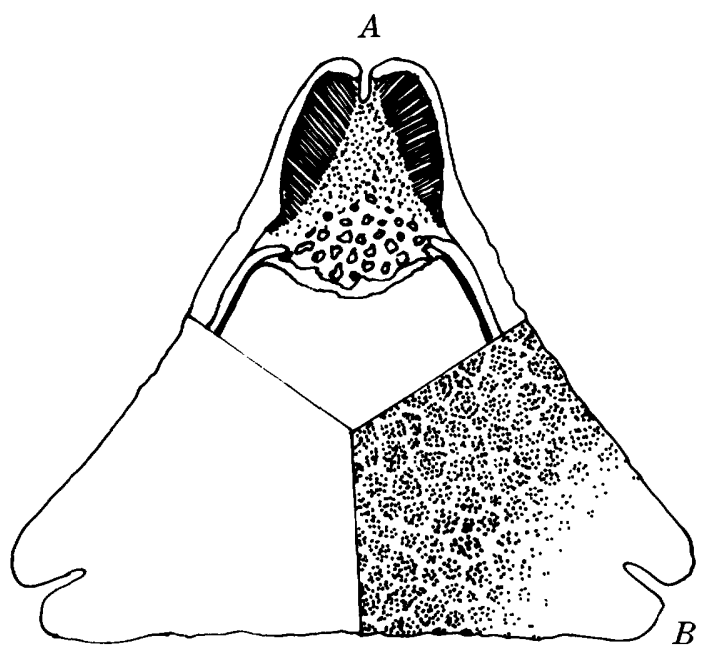

Figure 32. - Vacuopollis munitus, ca. $\times 2,000 . A$, Sectional view of aperture, showing baculate layer, internal verrucae in atrium, and two-layered endexine. $B$, Surface view showing shallow fossulate sculpture. 
concave triangular in polar view. Apertural areas only slightly bulging at the angles. Size $23 \mu-28 \mu$ in equatorial diameter (19 specimens). Wall of two principal layers, $2 \mu-3 \mu$ thick in the interapertural areas. Surface shallowly fossulate. Ektexine distinctly thicker than endexine, on some specimens two to three times as thick. Exogerminal vertical slit shaped, equatorial; the ektexine thickened (annulate) adjacent to the pore canal and consisting of two layers - an outer structureless area and an inner layer of tightly packed radially directed bacula. Baculate layer not visible on most specimens. Endogerminal very wide, extending almost entirely across base of apertural area. Endexine thin, consisting of two distinct layers broken up at the endogerminal to form one or more atria with somewhat irregular margins. Endexine in atria broken up into somewhat prominent isolated internal verrucae.

Remarks. - This species of Vacuopollis is somewhat similar to $V$. orthopyramis except that it has a distinctly thicker ektexine.

Stratigraphic Distribution. - McNairy Sand Member of Ripley Formation, McNairy Sand.

Genus Oscula POLlis, n. gen.

Type species. - Osculapollis aequalis, $\mathrm{n}$. sp.

Diagnosis. - Shape of pollen grains triangular to concave triangular, sometimes slightly convex triangular in polar view. Wall variously thick, endexine always thin. "Schichtfuge" or interloculum present. Surface smooth to slightly sculptured. Exogerminals in the form of small circular pores surrounded by annulate ektexine; ektexine in germinal areas two layered, outer layer structureless, inner of radially directed bacula. Narrow vestibulum present. Endogerminals somewhat circular, larger than exogerminals, endexine not enlarged adjacent to endogerminals.

Remarks. - The presence of porate exogerminals in Osculapollis distinguishes it from Trudopollis and Vacuopollis.

Osculapollis aequalis, n. gen., n. sp.

Plate 18, figures 10-20; text figure 33

Holotype. - Sample D3412, slide 4, coordinates 102.6×3.2, Coffee Sand, Tennessee, Campanian.

Paratype. - Sample D3412, slide 3, coordinates $98.5 \times 2.5$, Coffee Sand, Tennessee, Campanian.

Diagnosis. - Shape of pollen grains triangular, mostly concave triangular in polar view, with blunt apertural regions at the angles. Size $20 \mu-25 \mu$ in equatorial diameter (12 specimens). Wall about $1.5 \mu$ thick in interapertural areas, ektexine and endexine of about equal thickness and separated by a narrow interloculum. Surface smooth. Faint plicae or plicalike folds sometimes discernible. Exogerminals small circular equatorial pores surrounded by an annulate ektexine. Ektexine in germinal areas two layered, outer layer structureless and of uniform thickness over entire surface of grains, inner

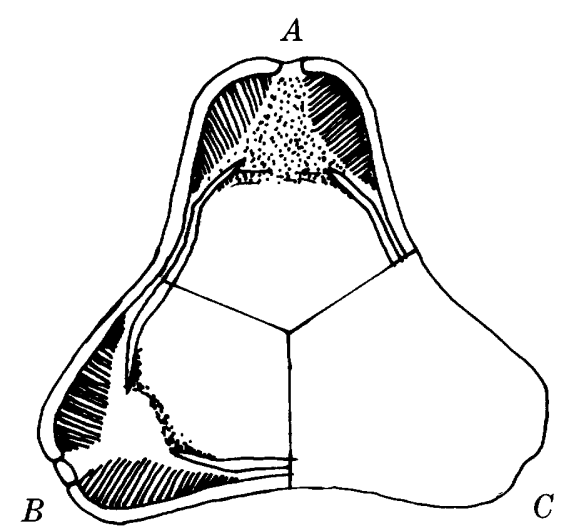

FIGURE 33. - Osculapollis aequalis, ca. $\times 2,000 . A, B$, Sectional views of apertures showing baculate layer, narrow interloculum, and thin endexine. $C$, Surface view, psilate.

layer of radially directed bacula that become progressively shorter toward the root of the exogerminal; end view of bacula in neck of exogerminal shows a granular appearance. A narrow vestibulum present. Endogerminal somewhat circular, larger than exogerminal and with irregular margin. Endexine thin, not enlarged adjacent to endogerminal, sometimes split into two lamellae in germinal areas.

Stratigraphic distribution. - Cusseta Sand Member of Ripley Formation and Coffee Sand.

Osculapollis perspectus, n. sp.

Plate 18, figures $21-27$, text figure 34

Holotype. - Sample D3412, slide 3, coordinates 104.1×16.3, Coffee Sand, Tennessee, Campanian.

Paratype. - Sample D3412, slide 3, coordinates 105.7 $\times 13.7$, Coffee Sand, Tennessee, Campanian.

Diagnosis. - Shape of pollen grains triangular to convex triangular with apertures at the angles. Apertural areas only slightly protruding. Size $20 \mu-29 \mu$ in equatorial diameter; most grains $20 \mu-24 \mu$ in diameter (based on 13 specimens). Wall $2 \mu-3 \mu$ thick in interapertural areas and smooth; ektexine about twice as thick as endexine,

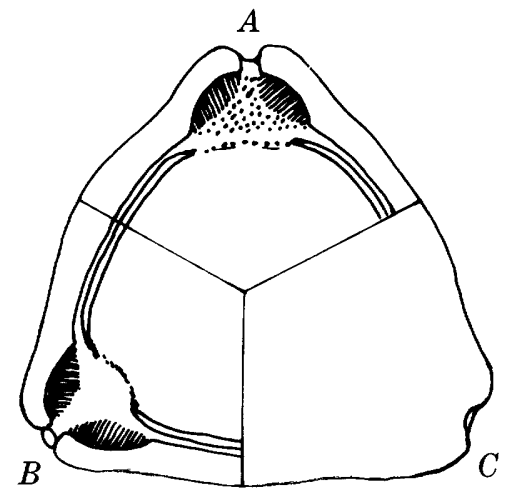

FIGURE 34. - Osculapollis perspectus, ca. $\times 2,000 . A, B$, Sectional views of germinals showing small semicircular baculate areas, thick ektexine, narrow interloculum, and thin endexine. $C$, Surface view, psilate. 
separated from it by a narrow interloculum. Exogerminals in the form of small circular pores surrounded by an annulate ektexine. Ektexine in pore areas two layered; outer layer smooth, and slightly thicker at base of the exogerminal than at the tip; inner layer consisting of a small, somewhat semicircular area of radially directed bacula. Endexine thin, about $0.5 \mu$ thick. A small, narrow vestibulum is present. Endogerminal larger than exogerminal, circular with distinctly irregular margins or lips.

Remarks. - Osculapollis perspectus can be distinguished from $O$. aequalis by its thicker ektexinal wall, its much smaller baculate areas, and the more acute angles at its germinals.

Stratigraphic distribution. - Coffee Sand.

Osculapollis sp. A

Plate 18, figures 28-31; text figure 35

Description. - Pollen grains concave triangular in polar view with blunt angles. Size $29 \mu-34 \mu$ in equatorial diameter (two specimens). Wall about $2 \mu$ thick in interapertural areas, endexine thinner than ektexine, surface smooth. Surface has the appearance of being granulate because of the presence of short bacula in the interloculum which separates ektexine from endexine. Exogerminals equatorial, in the form of small circular pores in the center of blunt apertural regions. Ektexine in pore areas two layered, outer layer structureless, slightly thicker at pore margin than otherwise; inner layer of crowded short bacula that become progressively shorter toward the root of the germinals and merge with bacula in the interloculum. No vestibulum, atrium roomy. Endexine thin, terminating in a plane margin at the base of the atrium.

Stratigraphic distribution. - Wilcox Formation.

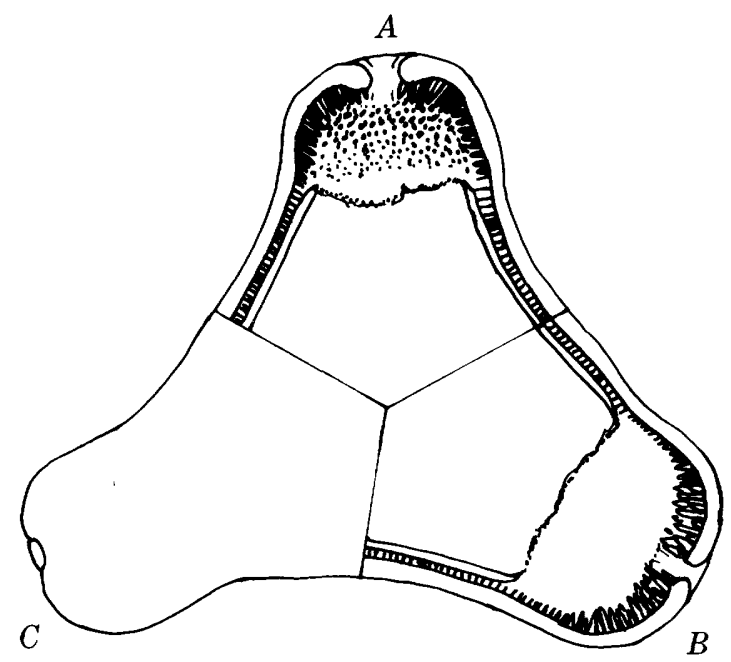

Figure 35. - Osculapollis sp. A., ca. $\times 2,000 . A, B$, Sectional views of apertures showing small equatorial exopores, baculate areas with bacula continuing into the interloculum, and thin endexine. $C$, Surface view, psilate.
Genus PRAECURSIPOLLIS, n. gen.

Type species. - Praecursipollis plebius, n. sp.

Diagnosis. - Pollen grains convex triangular in polar view with apertures at the angles. Size $16 \mu-21 \mu$ in equatorial diameter (20 specimens). Wall two layered, thin, ektexine about the same thickness as endexine, the combined layers about $1 \mu$ thick. Surface smooth, occasionally wall wrinkled, but this is incidental. Exogerminals circular pores, bordered by labra or small annuli. Ektexine in vicinity of pores two layered, the outer layer structureless, the inner consisting of very short radially directed bacula (often difficult to see). A shallow vestibulum present, as well as an atrium formed by the splitting of the endexine into two distinct layers in the vicinity of the endopore. Endopores slightly larger than exopores.

Remarks. - Distinguished from Neotriangulipollis by porate exogerminals and by two distinct endexinal lamellae adjacent to the endopores.

Praecursipollis plebius, n. gen., n. sp.

Plate 19, figures 1-10; text figure 36

Holotype. - Sample D3265, slide 3, coordinates 87.0×5.5, Eutaw Formation, Georgia, Coniacian.

Paratype. - Sample D3265, slide 4, coordinates 78.4 $\times 7.1$, Eutaw Formation, Georgia, Coniacian.

Diagnosis. - Monotypic. Same as for genus.

Stratigraphic distribution. - Eutaw Formation.

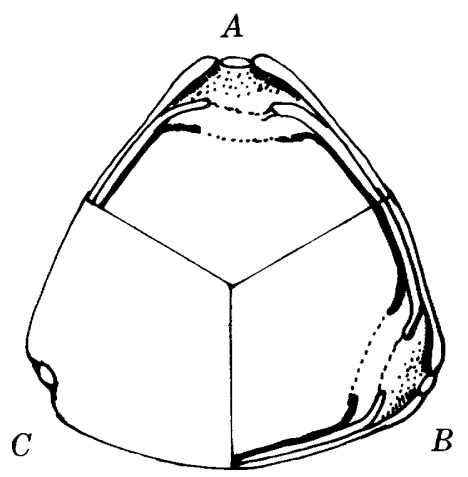

Figure 36. - Praecursipollis plebius, ca. $\times 2,000 . A, B$, Sectional views of apertures, showing pores, narrow baculate area, and split endexine forming two atria. $C$, Surface view, psilate.

Genus PSEUdATLANTOPOLLIs, n. gen.

Type species. - Pseudatlantopollis simulatus, n. sp. Diagnosis. - Shape of pollen grains triangular, slightly concave triangular, to slightly convex triangular in polar view, with equatorial germinals at the angles. Wall of two principal layers, ektexine thicker than endexine in the interapertural areas. Ektexine tectate, reticulate to foveolate with prominent columella layer. Exogerminals in the form of circular pores. Endexine thin in interapertural areas, separated into three to four bands or layers at the apertures, thus forming three or more irregularly defined successive atria. 


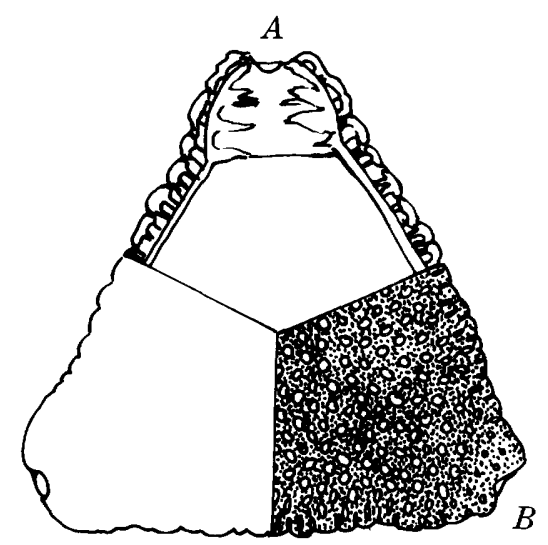

FIGURE 37. - Pseudatlantopollis simulatus, ca. $\times 2,000$. A, Sectional view of aperture showing tectate structure of ektexine and successive endexinal atria. $B$, Surface view showing foveolate-reticulate sculpture.

Pseudatlantopollis simulatus, n. gen., n. sp.

Plate 19, figures 11-28; text figure 37

Holotype. - Sample D1967-B, slide 10, coordinates $100.0 \times 18.9$, McNairy Sand Member, Ripley Formation, Tennessee, Maestrichtian.

Paratype. - Sample D1967-B, slide 9, coordinates 111.9×18.9, McNairy Sand Member, Ripley Formation, Tennessee, Maestrichtian.

Diagnosis. - Shape of pollen grains triangular, more often slightly concave triangular, sometimes slightly convex triangular in polar view with equatorial germinals at the angles of the grains. Size $20 \mu-26 \mu$ in equatorial diameter (35 specimens). Wall of two principal layers, $3 \mu-4 \mu$ thick in the interapertural areas. Ektexine thicker than endexine. Ektexine tectate with prominent reticulate sculpture; bacula supporting tectum easily seen at the periphery of the grains. Lumina of reticulum of same size over entire surface of the grains. Exogerminals in the form of circular pores, ektexinal sculpture somewhat thinner near pores. Endexine thin in interapertural areas, and separated into three to four bands or layers at the apertures to form three or more irregularly defined successive atria. Depth of apertural region including atria $5 \mu-7 \mu$.

Remarks. - This taxon bears some resemblance to Proteacidites. In the latter genus, however the endexine $\mathrm{s}$ not separated at the germinals, but all the lamellae are sused to form an endexinal annulus. Specimens of Proteacidites sp. are found in some of the samples that yield Pseudatlantopollis simulatus. These specimens of Proteacidites also differ from Pseudatlantopollis by possessing a reticulum whose lumina in the interapertural areas are distinctly larger than those at the poles or near the apertures. Pseudatlantopollis simulatus also bears a close resemblance to Atlantopollis, specifically Atlantopollis reticulatus, except that Atlantopollis is characterized by a vertical slit-shaped exogerminal, and the exogerminal of the genus Pseudatlantopollis is a circular pore.
Stratigraphic distribution. - Cusseta Sand Member of Ripley Formation, McNairy Sand Member of Ripley Formation, and Owl Creek Formation.

Genus ENDOINFUNDIBULAPOLLIs, n. gen.

Type species. - Endoinfundibulapollis distinctus, $\mathrm{n}$. sp.

Diagnosis. - Pollen grains triangular to slightly convex triangular in polar view with the germinals at the angles. Size $20 \mu-25 \mu$ in equatorial diameter (11 specimens). Wall thin, two layered, combined thickness in interapertural areas about $1 \mu$. Surface smooth or nearly so. Exogerminals short vertical slit shaped; ektexine adjacent to germinals labrate, two layered, the outer layer smooth and structureless, the inner layer of short, very tightly packed, radially directed bacula, baculate area tapering toward the root of the germinal. Structure in the inner layer often difficult to see. Vestibulum large, prominent double cone shaped. Endexine thin, reflexed inward in the form of a funnel at the apertures, endopore circular, $2 \mu-3 \mu$ in diameter at the base of the reflexed endexine. No endannulus, no interloculum.

Endoinfundibulapollis distinctus, n. gen., n. sp.

Plate 20, figures $1-11$; text figure 38

Holotype. - Sample D4268-B, slide 1, coordinates $78.5 \times 21.9$, McNairy Sand Member, Ripley Formation, Kentucky, Maestrichtian.

Paratype. - Sample D4268-B. slide 2, coordinates $79.2 \times 15.1$, McNairy Sand Member, Ripley Formation, Kentucky, Maestrichtian.

Diagnosis. - Monotypic, diagnosis as for genus.

Remarks. - The reflexed endexine is somewhat similar to that observed in Longanulipollis, except that the endexine is much thinner. Furthermore, the structure of the ektexine in the region of the exogerminals is entirely different. One specimen of Endoinfundibulapollis distinctus was observed to have a serendipitous air bubble within one endogerminal (pl. 20, figs. 1-5) that clearly demonstrates the size and shape of the endopore.

Stratigraphic distribution. - Coffee Sand and McNairy Sand Member of Ripley Formation.

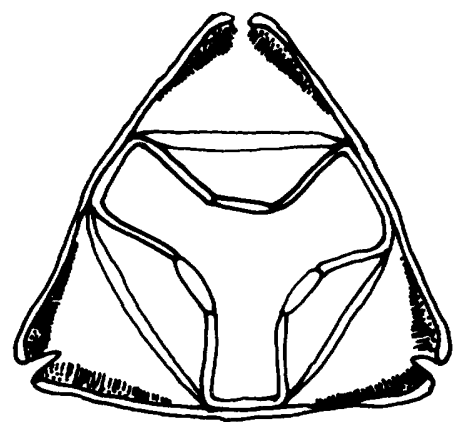

FIGURE 38. - Endoifundibulapollis distinctus, ca. $\times 2,000$. Apertures showing ektexinal vertical slit, baculate layer, and reflexed funnelshaped endexine and endopore. 
NEW GENUS A

Plate 20, figures 12-14, text figure 39

Description. - Pollen rigid triangular to slightly concave triangular in polar view. Size $31 \mu$ in equatorial diameter (one specimen). Wall thin, two layered, combined thickness about $1 \mu$. Ektexine fine verrucate to microverrucate. Germinals at the angles of the grain. Exogerminal a short vertical slit-shaped opening surrounded by a two-layered ektexine with an annulus. Outer layer structureless, inner layer of short radially directed bacula. Endexine forming a mesogerminal below a narrow vestibulum. A wide atriate endogerminal is developed centripetal to the mesogerminal. Base of atriate endogerminal marks an abrupt change in contour of the grains. Atrium roomy, $6 \mu-9 \mu$ deep. Centrifugal to the endogerminal, the endexine forms several internal partial annular ridges in the walls of the atrium.

Remarks. - This genus is distinguished from Triangulipollis by the more prominent atrium that marks a change in the outer contour of the grain and by the presence of annular ridges in the neck of the germinal. It is distinguished from Santonipollis, a genus that it superficially resembles, by its much shorter, more compact baculate area and by the presence of a prominent mesogerminal near the outer part of its germinals.

Stratigraphic distribution. - Eutaw Formation.

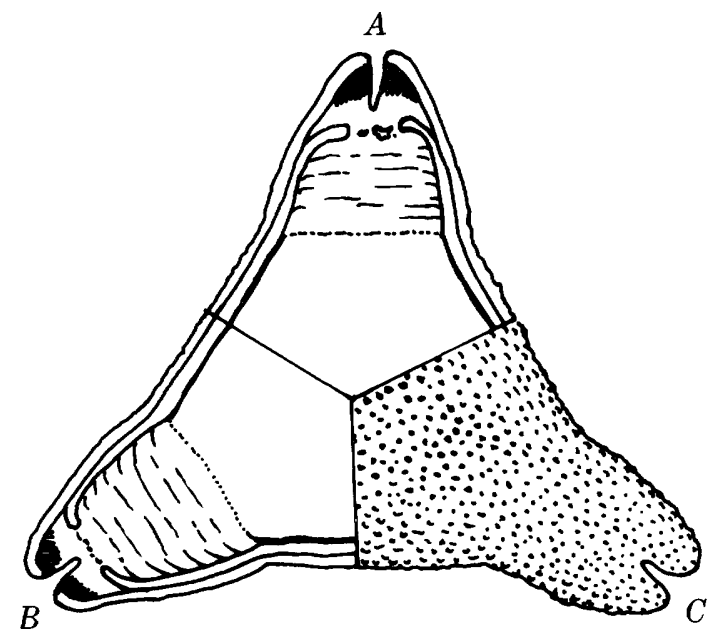

Figure 39. - New genus $\mathrm{A}$, ca. $\times 2,000 . A, B$, Sectional views of germinals showing baculate area, prominent mesogerminal, and deep atriate endogerminal. $C$, Surface view, verrucate.

\section{NEW GENUS B}

Plate 20, figures 15-17; text figure 40

Description. - Pollen triangular shallow lens shaped, with slightly bulging angles (germinals). Size $18 \mu-21 \mu$ in equatorial diameter (three specimens). Wall thin, about $1 \mu$ thick in interapertural areas; ektexine and endexine of about equal thickness; ektexine smooth. Exogerminal in the form of an elongate vertical slit. Aperture bordered by a prominent annulus tapering toward the root of the germinal. Ektexine in apertural area two layered, the outer of uniform thickness and structureless, the inner consisting of radially projecting tightly packed bacula. Vestibulum prominent, roomy. Endexine thin, projecting inward below the exogerminals and the vestibulum forming a short, parallelwalled channel. Endogerminals at base of infolded endexine. Endexinal apertures small circular pores; margins of endexine adjacent to pore slightly thickened.

Remarks. - Distinguished from Longanulipollis by the presence of a prominent baculate layer adjacent to the exogerminal and by a much thinner endexine. This genus is somewhat similar to Endoinfundibulapollis in the possession of a reflexed endexine; however, the exogerminal development is much more prominent in new genus $B$, and it possesses a slight endexinal thickening adjacent to the endopore.

Stratigraphic distribution. - Coffee Sand.

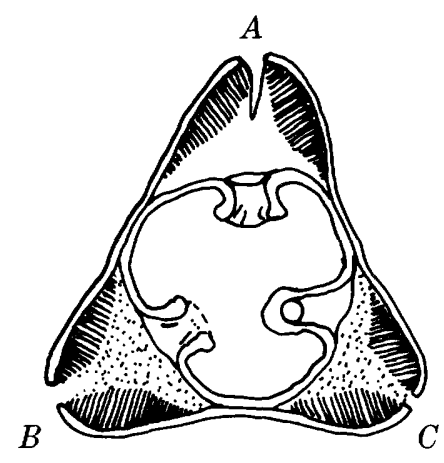

FigURe 40. - New genus $\mathrm{B}$, ca $\times 2,000 . A, B$, Sectional views showing slit-shaped exogerminals, baculate layer, and inward-projecting endexine forming channeled endopore. $C$, Endopore channel twisted, showing equatorial view of pore.

\section{NEW GENUS $\mathbf{C}$.}

Plate 20, figures 18-20; text figure 41

Description (Incomplete). - Pollen grains triangular in polar view with large apertural regions at the angles. Size $28 \mu$ in equatorial diameter (one specimen). Surface smooth. Exogerminal vertical slit shaped, ektexine adjacent to exogerminals thin, inner part of wall studded with scattered, radially directed fairly coarse bacula, arranged somewhat in the form of successive annular ridges. Vestibulum prominent. Endexine thick, particularly in the apertural region. Endopores small surrounded by thick unstructured annuli. Endexine thicker than ektexine.

Remarks. - I have been unable to determine with certainty whether what appear to be heavy endexinal arci are actual, or whether their purported appearance is caused by the irregular wrinkling of the specimen in the interapertural regions.

Stratigraphic distribution. - Owl Creek Formation. 


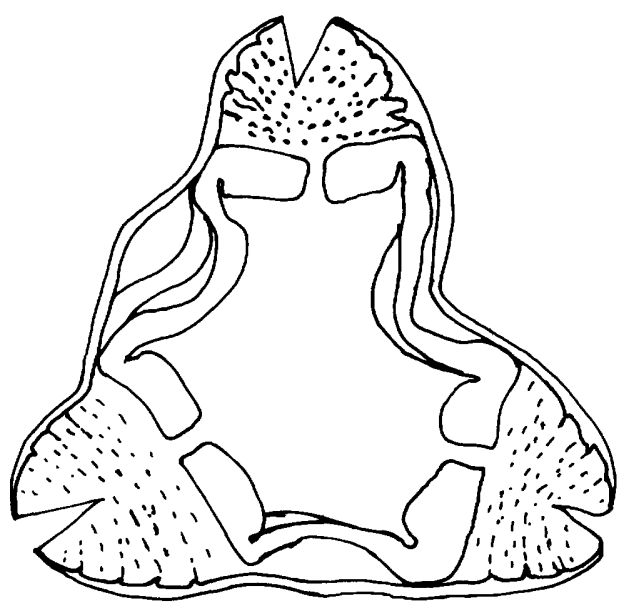

Figure 41. - New genus C, ca. $\times 2,000$. Sectional views of apertures with short bacula in outer part and prominent endexinal thickenings adjacent to the endopores.

\section{NEW GENUS D}

Plate 20, figures 21-23; text figure 42

Description. - Pollen grains circular to convex triangular in polar view, with equally spaced equatorial apertures. Size $44 \mu$ in equatorial diameter (one specimen). Wall of two principal layers, about $2 \mu$ thick in interapertural areas, ektexine and endexine of about equal thickness separated by a narrow interloculum. Surface smooth. Exogerminal in the form of a vertical narrow slit extending about half the distance to the poles. Ektexine of uniform thickness except near the exogerminal, where it narrows abruptly. Endexine also narrows near the exogerminal, then thickens in the mesogerminal region, then thins again in the interapertural areas. Inner portion of endexine shows continuous exfoliation pattern within the large roomy atrium. Irregular short bacula form a somewhat annulate pattern more prominent in the middle part of atrium than above or below. Innermost layer of endexine is visible only as a lower limit to the atrium and at the sides as a thin, more refractive layer.

Remarks. - This specimen is included in the Normapolles assemblage because of the vertical slit-shaped exogerminal and the complicated exfoliation pattern of the endexine present in the large atrium.

Stratigraphic distribution. - Owl Creek Formation.

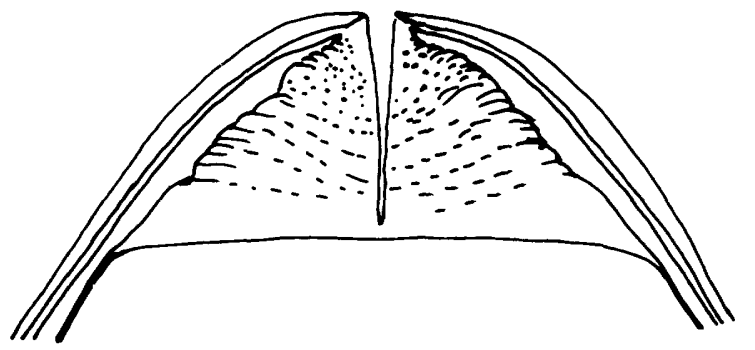

FIGURE 42. - New genus D. One aperture, ca. $\times 2,000$. Deep vertical slit, extexine, interloculum, and exfoliation pattern within the atrium shown.

\section{KEY TO MISSISSIPPI EMBAYMENT NORMAPOLLES GENERA}

A conspicuous feature of the pollen grains of many Normapolles genera is the presence of vertical slit-shaped exogerminals. Other Normapolles genera, in contrast, possess circular porate exogerminals. Pollen of some Normapolles genera or species may possess an exogerminal constructed of only a slit or vertically oval exogerminal. Those pollen grains, whose exogerminals might be misinterpreted because of small size or orientation of the specimens, have been keyed to both the slit-shaped and the porate categories below.

A. Exogerminals, $6 ; 3$ subequatorial on each hemisphere

B. Wall thin, with an equatorial constriction, usually with interloculum _._. Interpollis

BB. Wall thick, without equatorial constriction, no interloculum _._._. Interporopollenites

AA. Exogerminals, 3; equatorial or nearly so

C. Exogerminals vertical slit shaped

D. Endogerminals (mesogerminals) prominently equatorial slit shaped at right angle to exogerminal opening

E. Typical polyannulate exogerminal with at least one prominent praevestibulum _........ Basopollis

EE. No praevestibulum in exogerminal

F. Ektexine and endexine thin, both of about equal thickness.

G. Plicae prominent, terminating in a triangular point within vestibula _._.

GG. No typical plicae present _._.

FF. Ektexine significantly thicker than endexine _._._- Choanopollenites

DD. Endogerminals somewhat circular to oval

H. Prominent oculi present on one hemisphere only

I. Oculi joined over one pole by a prominent external thickening _._.

II. Oculi clearly isolated-not connected over one pole _- Semioculopollis 
HH. Prominent oculi not present

J. Large roomy atria or vestibula extending more than half the apertural radius (measured from the exterior of the exogerminals toward the pole to the inner limit of the atria or vestibula); openings of endogerminals much larger than those of exogerminals.

$K$. Endogerminals with a deep $V$-shaped incidence or cuneus.

L. Ektexine conspicuously thickened and protruding adjacent to pore canal; endexine of only one distinct layer or lamella. Extremipollis

LL. Ektexine usually not prominently thickened and protruding adjacent to the pore canal; endexine thin, consisting of two or more distinct layers at the endogerminals, forming thereby successive atria. _._._._._._. Vacuopollis

KK. Endogerminal borders shallow crescent shaped _._._._._._._._._._._._. Megatriopollis

JJ. Atria or vestibula much smaller, extending half or less the apertural radius.

M. Small forms, $16 \mu$ or less in diameter. $\ldots \ldots \ldots$. MM. Larger forms, usually larger than $20 \mu$ in diameter.

$\mathrm{N}$. With a prominent vestibulum.

O. Diameter of endogerminal openings only slightly smaller than diameter of vestibulum; exogerminals labroid; no interloculum - Pecakipollis

OO. Diameter of endogerminal openings much less than diameter of vestibulum; exogerminals annulate, swollen; interloculum usually present Trudopollis

NN. No vestibulum, no interloculum, mesogerminal consisting of a basketlike filter. - $--\ldots--$ Nudopollis

CC. Exogerminals circular pores, or at most slightly oval.

$P$. Outline of pollen grains circular or nearly so.

Q. Platea and interloculum present _._._._._. Pompeckjoidaepollenites

QQ. No development of platea.

R. Endexine reflexed inward around endopores _._._.

RR. Endexine not reflexed inward, endexine of two prominent layers

Kyandopollenites

PP. Outline of pollen grains triangular, concave triangular or convex triangular.

S. With prominent plicae.

$\mathrm{T}$. Plicae terminating in a triangular flap within the vestibulum _.

TT. Plicae terminating at base of vestibulum, no pointed flap present _.--

SS. Without prominent plicae.

$$
\text { - }
$$

U. Platea and interloculum present

UU. No platea present.

V. Inner part of ektexine thickened or swollen in interapertural areas. - - - - - - -

VV. Ektexine almost the same thickness throughtout.

W. Interloculum present _._._. WW. No interloculum.

X. Prominent reticulate tectum present

Pseudatlantopollis

$\mathrm{XX}$. Without reticulate tectum.

Y. Endexine annulate or split into several lamellae adjacent to endogerminal.

Z. Wail thin, vestibulum very shallow; baculate area of exogerminals poorly developed; successive atria formed by splitting of endexine _._._._._._-_Praecursipollis

ZZ. Wall thicker, vestibulum deep, roomy; baculate area of exogerminals well developed _._._._._._. Pecakipollis

YY. Endexine not annulate nor split into several lamellae adjacent to endogerminal.

a. Endexine strongly reflexed inward below vestibulum, terminating in a small pore _._._._._._._Endoinfundibulapollis

aa. Endexine not reflexed inward; small forms less than $16 \mu$ in diameter _.....Minorpollis 


\section{STRATIGRAPHIC DISTRIBUTION OF NORMAPOLLES GENERA}

Genera assignable to the Normapolles group are limited in Europe to the Late Cretaceous and early Tertiary. They first appear in the basal part of the Cenomanian, attain their greatest development during the Santonian and Maestrichtian Stages and gradually decrease in number during the early Tertiary. Only one genus, Plicapollis, persists beyond the Eocene into the early Oligocene, all others have become extinct by the end of Eocene time. A chart showing the stratigraphic distribution of the European Normapolles genera is provided by Góczán and others (1967, p. 540). Although a few Normapolles genera, notably Thomsonipollis, were known from the North American continent in 1967, data concerning these genera were largely omitted from that treatise.

Normapolles genera first appear in Mississippi embayment rocks during the Cenomanian. Complexiopollis is the lone Normapolles genus to appear in the Tuscaloosa Formation sample. In the Coniacian, four genera were recognized; one of these, however, new genus A, was represented by but a single specimen - an insufficient number to permit assigning generic and specific epithets. The Campanian is represented by 15 genera and the Maestrichtian by 18 genera. A decline in numbers of genera begins in the Paleocene which is represented by only 8 genera. The lower Eocene Wilcox Group yielded specimens of 10 genera; by the middle Eocene (Claiborne time) this number had abruptly decreased to 1 (Nudopollis). The upper Eocene formations examined failed to yield any specimens assignable to Normapolles genera, although Fairchild and Elsik (1969) stated that they had seen several specimens of Nudopollis terminalis in the late Eocene Jackson Group.

In Europe, the greatest number of Normapolles genera is attained during the Santonian, followed by a second peak of abundance during the Maestrichtian and two minor peaks in the early Tertiary (Góczán and others, 1967). In the Mississippi embayment the greatest number of genera was observed in the CampanianMaestrichtian interval. Thus, the development of Normapolles genera in the Mississippi embayment approximately parallels the development of those genera in Europe. As the sampling interval in the lower part of the Campanian and older stages was very sparse in the Mississippi embayment, it is pointless to try to compare in detail the European and Mississippi embayment maxima.

Fifty-seven genera are included in the European Normapolles complex by Góczán, Groot, Krutzsch, and Pacltová (1967). Forty-seven of these genera were from boreal middle Europe and 10 were confined to western Hungary with but four Normapolles genera common to the two European regions. Only 18 of these 57 genera are recorded from Mississippi embayment samples. To this number must be added the two genera erected by Stover (in Stover and others, 1966) Kyandopollenites and Choanopollenites, and the genera established as a result of the present work, Osculapollis, Praecursipollis, Pseudatlantopollis, and Endoinfundibulapollis. This makes a total of 24 Normapolles genera from Mississippi embayment rocks, exclusive of the four possible new genera that were not named because of insufficient numbers of specimens.

Figure 43 compares the stratigraphic distribution of these genera in Europe and in the Mississippi embayment.

Of the genera common to Europe and the Mississippi embayment, several show remarkably similar stratigraphic ranges in the two areas, notably Complexiopollis, Trudopollis, Pseudoplicapollis, Nudopollis, Interpollis, and Thomsonipollis. The sample coverage from the early Campanian through the Cenomanian is poor in the Mississippi embayment. As more samples are examined from this interval, undoubtedly additional Normapolles genera will be identified and the stratigraphic ranges of others will be extended.

The ranges of several genera are distinctly different in Europe and in the Mississippi embayment. Plicapollis and Vacuopollis have ranges in Europe extending from the Turonian or Coniacian into the Eocene, and Plicapollis even into the basal Oligocene. In the Mississippi embayment their known ranges are limited to the Campanian and Maestrichtian. This discrepancy is difficult to explain. These genera apparently died out earlier in the Mississippi embayment than in Europe. A similar pattern is observed for the genus Minorpollis. However, this genus is considered by European workers as a collection genus for small pollen grains that may be difficult to diagnose. (See Góczán and others, 1967, p. 478.) Consequently, several genera may be included in the European range of this form genus.

Genera such as Megatriopollis and Pecakipollis may be as rare in European rocks as they are in rocks from the Mississippi embayment; consequently, although, at present, their stratigraphic ranges do not coincide, further work may extend the ranges in one or both areas and so greater coincidence may be forthcoming.

Pompeckjoidaepollenites has a range in Europe extending from the Coniacian into the late Eocene. In Mississippi embayment samples specimens of this genus were observed only in the upper part of the lower Eocene. This apparent discrepancy may be due to the rarity of specimens of this genus in this area. This genus very clearly is derived from the Trudopollis stock. Parallel evolution taking place later in the Mississippi embayment than in Europe or later immigration from Europe could explain the later first appearance of the genus in the Mississippi embayment. 


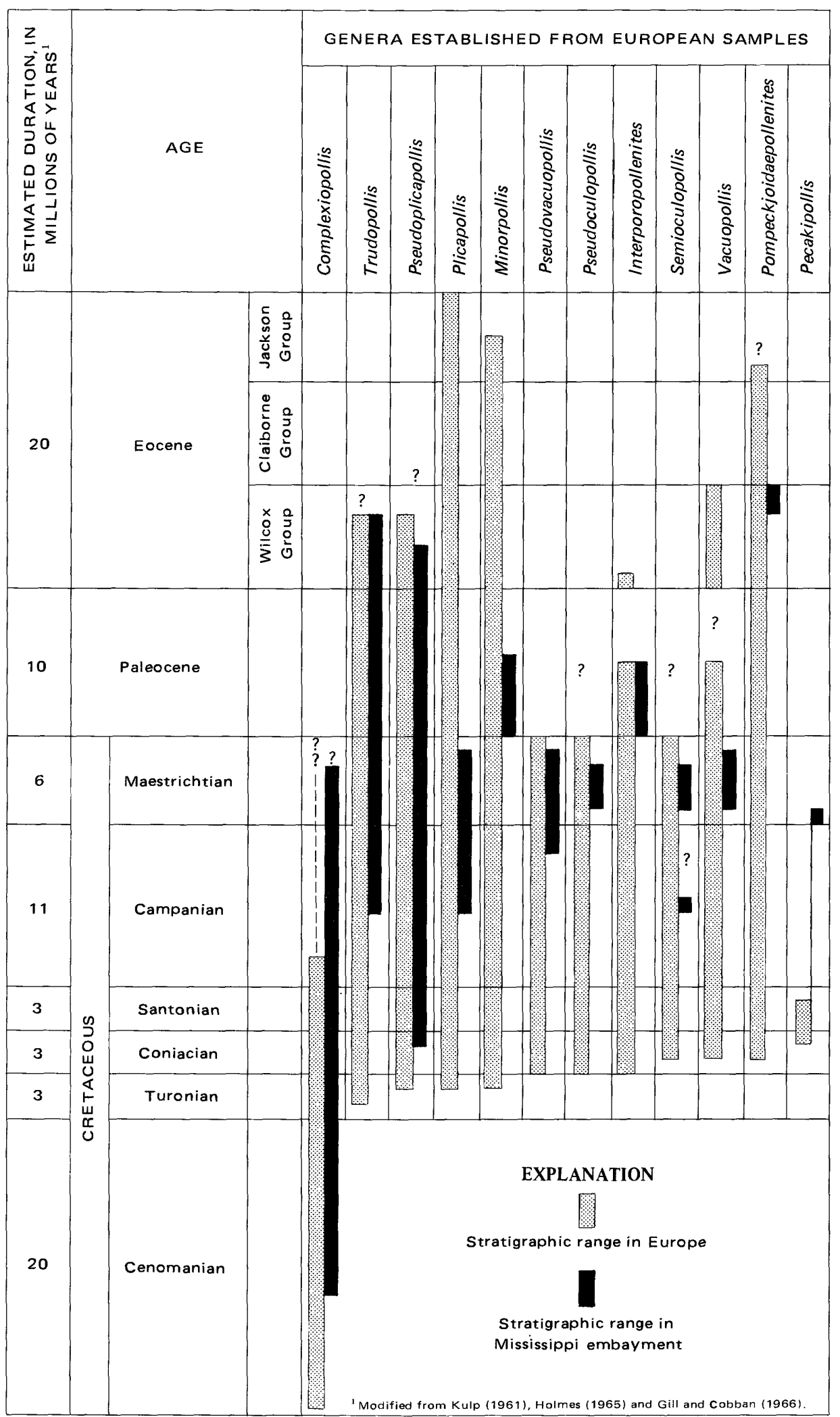

FIGURE 43. - Comparison of stratigraphic distribution of Normapolles 


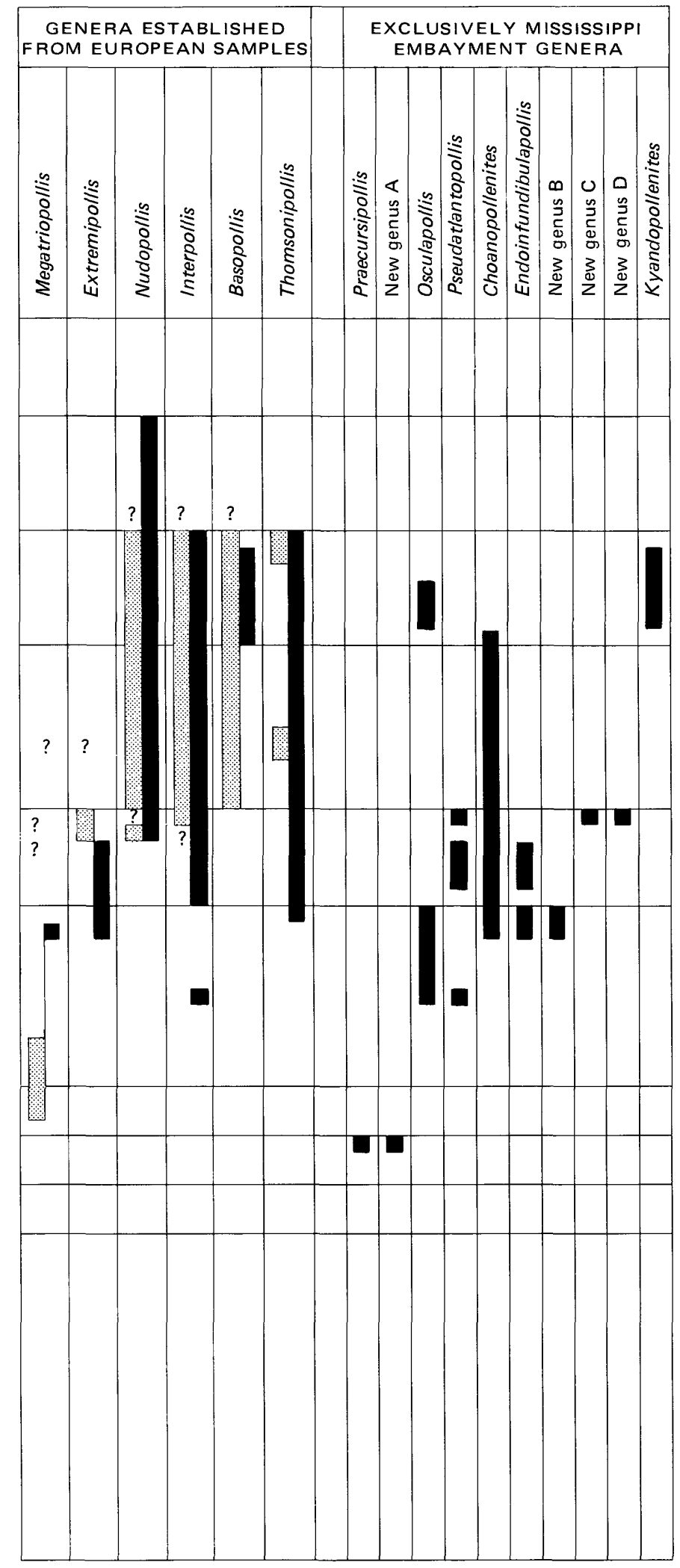

genera in Europe and Mississippi embayment.
The genera Thomsonipollis, Interpollis, and Extremipollis appear earlier in the stratigraphic column in the Mississippi embayment than in Europe. This fact would seem to contradict the suggestion of Góczán, Groot, Krutzsch, and Pacltová (1967) that central Europe is the center of development of the Normapolles group. Certainly, so far as genera are concerned, many more Normapolles genera are known from Europe than from the Mississippi embayment. However, certain genera, because of their rarity may not yet have been found in rocks as old in Europe as in North America. An alternative hypothesis is one that would allow for the origin of certain Normapolles genera in Europe and others in North America. It must be remembered that the Normapolles group is a group of convenience. No one has implied genetic relationship of all the genera included. Quite the contrary, it is evident on a morphologic basis that such genera as Interpollis and Nudopollis have little in common and probably originated from widely divergent plant stems. If the continents were at one time close enough to permit plant migration from east to west, there could as well have been migration from west to east. A further argument for independent origin in North America of genera now assigned to the Normapolles group is seen in the fact that the genera Choanopollenites, Kyandopollenites, Osculapollis, Praecursipollis, Pseudatlantopollis, Endoinfundibulapollis, and four new unnamed genera have been found in Mississippi embayment rocks. None of these genera has been reported from Europe.

\section{STRATIGRAPHIC DISTRIBUTION OF NORMAPOLLES SPECIES}

Normapolles species have proved to be excellent index fossils in Europe. They have the same stratigraphic utility in the Mississippi embayment. Individual specimens often can provide preliminary information concerning the stratigraphic placement of a sample. When used in conjunction with assemblages of other Normapolles species and other pollen and spore species, their stratigraphic value is enhanced remarkably.

Fifty-nine Normapolles species have been recognized from Mississippi embayment rocks. Of this number, 43 species have been found in sufficient numbers for specific names to be assigned. The remainder are referred to by generic designation only. It is notable that the greater proportion of species recognized could not be equated with European species. The great proportion of new species suggests that the Mississippi embayment genera and species were at least somewhat isolated from their European counterparts.

Mississippi embayment species have been plotted in 


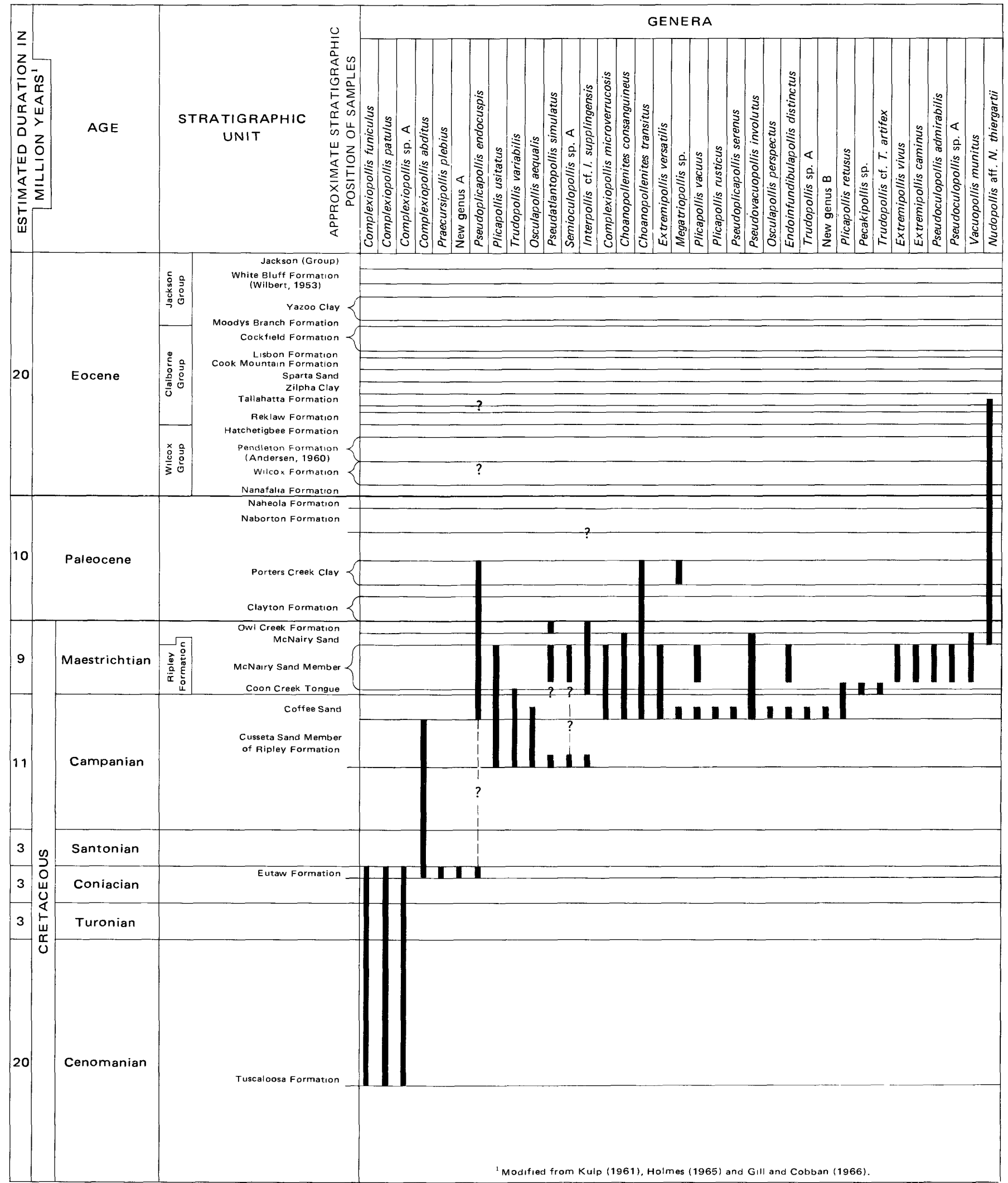

FIGURE 44 (above and tacing page). - Stratigraphic ranges of Normapolles species in Mississippi embayment. 


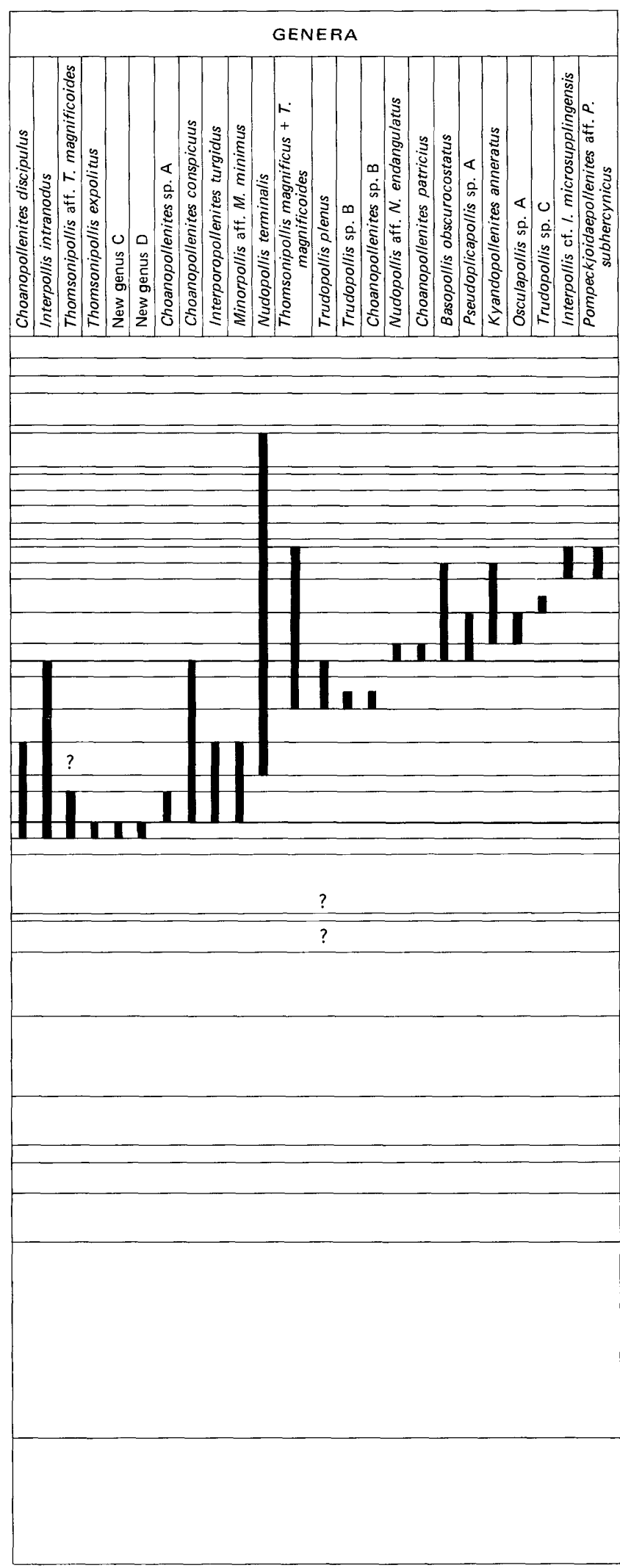

FIGURE 44. - Continued. stratigraphic sequence in figure 44 . This figure portrays the sequential development of Normapolles species in Mississippi embayment rocks. Beginning in the Cenomanian three species were recognized, all belonging to the genus Complexiopollis. In succeeding younger samples, development continues to be expressed in the form of increased numbers of species. In the Coniacian, 7 species were found; in the Campanian, 22; and in the Maestrichtian, 28. This species peak in the Maestrichtian is followed by a decline in the Paleocene to 16 species, then to 12 species in the early Eocene, and to only 2 in the middle Eocene. In the Mississippi embayment rocks examined, no Normapolles genus or species originates in rocks younger than those of the upper part of the Wilcox. Concurrently, all Normapolles species apparently became extinct in North America by the end of middle Eocene time.

\section{REFERENCES}

Andersen, H. V., 1960, Geology of Sabine Parish: Louisiana Geol. Survey Geol. Bull. 34, 164 p.

Brown, C. W., and Pierce, R. L., 1962, Palynologic correlations in Cretaceous Eagleford Group, northeast Texas: Am. Assoc. Petroleum Geologists Bull., v. 46, no. 12, p. 2133-2147.

Chmura, C. A., 1973, Upper Cretaceous (Campanian-Maestrichtian) angiosperm pollen from the western San Joaquin Valley, California, U.S.A.: Palaeontographica, ser. B., v. 141, p. 89-171.

DeVries, D. A., 1963, Jasper County mineral resources: Mississippi Geol. Econ. and Topog. Survey Bull. 95, p. 10-52.

Doyle, J. A., 1969, Cretaceous angiosperm pollen of the Atlantic Coastal Plain and its evolutionary significance: Jour. Arnold Arboretum, v. 50 , no. 1 , p. 1-35.

Drugg, W. S., 1967, Palynology of the upper Moreno Formation (Late Cretaceous-Paleocene), Escarpedo Canyon, California: Paleontographica, ser. B., v. 120 , nos. 1-4, p. 1-71.

Elsik, W. C., 1968, Morphology and taxonomy (end), [Pt] 2 of Palynology of a Paleocene Rockdale lignite, Milam County, Texas: Pollen et Spores, v. 10, no. 3, p. 599-664.

Engelhardt, D. W., 1964, Plant microfossils from the Eocene Cockfield Formation, Hinds County, Mississippi: Mississippi Geol. Econ. and Topog. Survey Bull. 104, p. 65-95.

Fairchild, W. W., and Elsik, W. C., 1969, Characteristic palynomorphs of the lower Tertiary in the Gulf Coast: Palaeontographica, ser. B., v. 128 , nos. $3-6$, p. 81-89.

Foster, V. M., 1940, Lauderdale County mineral resources - Geology: Mississippi Geol. Survey Bull. 41, 246 p.

Frederiksen, N. O., 1973, New mid-Tertiary spores and pollen grains from Mississippi and Alabama: Tulane Studies in Geology and Paleontology, v. 10, no. 2, p. 65-86.

Gill, J. R., and Cobban, W. A., 1966, The Red Bird section of the Upper Cretaceous Pierre Shale in Wyoming, with a section on A new echinoid from the Cretaceous Pierre Shale of eastern Wyoming, by Porter M. Kier: U.S. Geol. Survey Prof. Paper 393-A, 73 p.

Góczán, Ferenc, Groot, J. J., Krutzsch, Wilfried and Pacltová, Blanka, 1967, Die Gattungen des "Stemma Normapolles Pflug, 1953b" (Angiospermae) - Neubeschreibungen und Revision europäischer Formen (Oberkreide bis Eozën): Paläont. Abhandlungen, ser. B., v. 2 , no. 3 , p. $427-633$. 
Gray, T. C., and Groot, J. J., 1966, Pollen and spores from the marine Upper Cretaceous formations of Delaware and New Jersey: Palaeontographica, ser. B, v. 117, nos. 4-6, p. 114-134.

Groot, J. J., and Groot, C. R., 1962, Some plant microfossils from the Brightseat Formation (Paleocene) of Maryland: Palaeontographica, ser. B., v. 111, p. 161-171.

Groot, J. J., Penny, J. S. and Groot, C. R., 1961, Plant microfossils and age of the Raritan, Tuscaloosa and Magothy Formations of the Eastern United States: Palaeontographica, ser. B., v. 108, p. 121-140.

Holden, F. T., Hughes, U. B., Mellen, F. F., and Spooner, K. K., compilers, 1948, The stratigraphy and paleontology of the Eocene, Oligocene and Miocene of Clarke and Wayne Counties, Mississippi [notes and plates], in Mississippi Geol. Soc. Guidebook, 6th Field Trip, 1948, p. 52-74 (reprinted from Shreveport Geol. Soc. Guidebook, 11th Ann. Field trip, 1934).

Holmes, Arthur, 1965, Principles of physical geology [revised ed.]: New York, Ronald Press Co., 1288 p.

Jones, E. L., 1962, Palynology of the Midway-Wilcox boundary in south-central Arkansas: Gulf Coast Assoc. Geol. Socs., Trans., v. 12 , p. $285-294$.

Kimyai, Abbas, 1966, New Plant microfossils from the Raritan Formation (Cretaceous) in New Jersey: Micropaleontology, v. 12, no. 4, p. $461-476$.

Kremp, G. O. W., 1965, Morphologic encyclopedia of palynology: Arizona Univ. Press, 185 p.

Krutzsch, Wilfried, 1954, Bemerkungen zur Benennung und Klassifikation fossiler (insbesondere tertiärer) Pollen und Sporen: Geologie, v. 3, no. 3, p. 258-311.

Krutzsch, Wilfried, 1959, Einige neue Formgattungen und -arten von Sporen und Pollen aus der Mitteleuropäischen Oberkreide und dem Tertiär: Palaeontographica, ser. B., v. 105, nos. 5-6, p. 125-157.

1960a, Uber Thomsonipollis magnificus (Th. and Pf. 1953) n. f. gen. n. comb. und Bemerkungen zur regionalen Verbreitung einiger Pollengruppen im älteren Paläogen: Freiberger Forschungshefte, v. C86, p. 54-65.

1960b, Beitrag zur Sporenpaläontologie der präoberoligozänen kontinentalen und marinen Tertiärablagerungen Brandenburgs: Geol. Gesell. DDR Berichte, v. 5, no. 4, p. 290-343.

1961, Zum Typus von "Pollenites pompeckji R. Pot., 1931a" und von "Trudopollis subhercynicus Krutzsch 1954a": Geologie, v. 10 , no. 32 , p. $94-96$.

Kulp, J. L., 1961, Geologic time scale: Science, v. 133, no. 3459, p. 1105-1114.

Kunert, Reinhard, and Lenk, Günter, 1964, Das Tertiär nördlich der Halle-Hettstedter Gebirgsbrüke: Geologie, v. 13, no. 4, p. 403-428.

Leopold, E. B., and Pakiser, H. M., 1964, A preliminary report on the pollen and spores of the pre-Selma Upper Cretaceous strata of western Alabama: U.S. Geol. Survey Bull. 1160-E, p. 71-95.

MacNeil, F. S., 1946, Geologic map of the Tertiary formations of Alabama; U.S. Geol. Survey Oil and Gas Inv. (Prelim.) Map 45.

Mellen, F. F., 1940, Geology, [Pt. 1] of Yazoo County mineral resources: Mississippi State Geol. Survey Bull. 39, p. 9-72.

Moore, W. H., 1965, Hinds County geology: Mississippi Geol. Econ. and Topog. Survey Bull. 105, p. 21-145.

Newman, K. R., 1965, Upper Cretaceous-Paleocene guide palynomorphs from northwestern Colorado: Colorado Univ. Studies Ser. Earth Sci. no. 2, 21 p.
Pflug, H. D., 1953, Zur Entstehung und Entwicklung des angiospermiden Pollens in der Erdgeschichte: Palaeontographica, ser. B., v. 95 , nos. $4-6$, p. $60-171$.

Potonié, Robert, 1934, Zur Microbotanik der Kohlen und ihrer Verwandten, II, Zur Microbotanik des eocänen Humodils des Geiseltals: Preuss. Geol. Landesanstalt, Inst. Paläobot. und Petrog. Brennsteine, Arb., v. 4, p. 25-125.

Priddy, R. R., 1960, Madison County geology: Mississippi Geol. Survey Bull. 88, 123 p.

1961, Geology study along Highway 80 from Alabama line to Jackson, Mississippi: Mississippi Geol. Survey Bull. 91, 62 p.

Skarby, Annie, 1968, Extratriporopollenites (Pflug) emend. from the Upper Cretaceous of Scania, Sweden: Stockholm Contr. Geology, v. $16,60 \mathrm{p}$.

Smith, F. E., 1959, Lower Tertiary and Upper Cretaceous of Brazos River Valley, Texas, in Houston Geol. Soc. and Gulf Coast Geol. Assoc., Soc. Econ. Paleontologists and Mineralogists Gulf Coast sec., Guidebook, Ann. Field Trip, 1959: 54 p.

Stenzel, H. B., 1938, The geology of Leon County, Texas: Texas Univ. Bur. Econ. Geology Pub. 3818, 295 p. [1939].

Stephenson, L. W., and Monroe, W. H., 1940, The Upper Cretaceous deposits [Mississippi]: Mississippi Geol. Survey Bull. 40, 296 p.

Stover, L. E., Elsik, W. C. and Fairchild, W. W., 1966, New genera and species of early Tertiary palynomorphs from Gulf Coast: Kansas Univ. Paleont. Contr., Paper 5, p. 1-11.

Thomson, P. W., and Pflug, Hans, 1953, Pollen und Sporen des Mitteleuropäischen Tertiärs: Palaeontograhica, ser. B., v. 94, nos. $1-4,138 \mathrm{p}$.

Tschudy, B. D., 1971, Two new fossil pollen genera from Upper Campanian (Cretaceous) rocks of Montana, in Geological Survey research 1971: U.S. Geol. Survey Prof. Paper 750-B, p. B53-B61.

Tschudy, R. H., 1966, Associated megaspores and microspores of the Cretaceous genus Ariadnaesporites Potonié, 1956, emend., in Geological Survey research 1966: U.S. Geol. Survey Prof. Paper 550-D, p. D76-D82.

1970, Two new pollen genera (Late Cretaceous and Paleocene) with possible affinity to the Illiciaceae: U.S. Geol. Survey Prof. Paper 643-F, 13 p.

1973a, Stratigraphic distribution of significant Eocene palynomorphs of the Mississippi embayment: U. S. Geol. Survey Prof. Paper, 743-B, 24 p.

1973b, The Complexiopollis pollen lineage in Mississippi embayment rocks: U.S. Geol. Survey Prof. Paper 743-C, 15 p.

Vestal, F. E., 1943, Choctaw County mineral resources- Geology: Mississippi State Geol. Survey Bull. 52, 156 p.

1954, Marshall County geology: Mississippi Geol. Survey Bull. 78, $193 \mathrm{p}$.

Weyland, Hermann, and Krieger, Wilhelm, 1953, Die Sporen und Pollen der Aachener Kreide und ihre Bedeutung für die Charakterisierung des Mittleren Senons: Palaeontographica, ser. B, v. 95 , nos. $1-3$, p. 6-29.

Wilbert, L. J. Jr., 1953, The Jacksonian Stage in southeastern Arkansas: Arkansas Resources and Devel. Comm., Div. Geology Bull. 19, $125 \mathrm{p}$.

Wolfe, J. A., and Pakiser, H. M., 1971, Stratigraphic interpretations of some Cretaceous microfossil floras of the Middle Atlantic States, in Geological Survey research 1971: U.S. Geol. Survey Prof. Paper 750-B, p. B35-B47. 


\section{INDEX}

[Italic page numbers indicate major references]

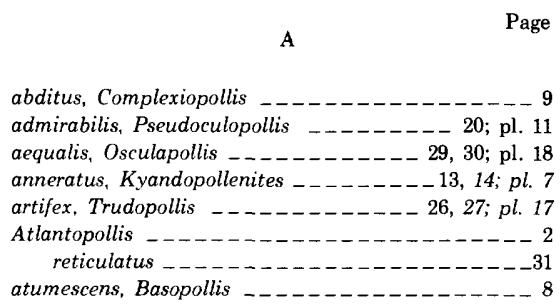

basalis, Basopollis _._.

Basopollis____._.

atumescens _-_-

basalis _-

obscurocostatus _- -

ornatus _._.

orthobasalis _._.

Bohemiapollis _._-_._._-

bohemiensis, Pecakipollis__.__..__.

\section{$\mathrm{C}$}

caminus, Extremipollis _Choanopollenites _._. consanguineus _..._conspicuus _._-_._discipulus _._. eximius _patricius _- - - - - - - - - - - transitus _. sp. _- $\ldots \ldots \ldots \ldots \ldots$

Complexiopollis _._. abditus _..funiculus _._. microverrucatus _._. patulus _._._praeatumescens _concentricoides, Pseudoculopollis concentus. Oculopollis _Conclavipollis _._._. consanquineus, Choanopollenites _........... 8 conspicuus, Choanopollenites _-

Nudopollis thiergartii _..--

D

discipulus. Choanopollenites

distinctus, Endoinfundibulapollis $\mathrm{E}$

Emscheripollis _endangulatus, Extratriporopollenites _- $\ldots \ldots \ldots-15$

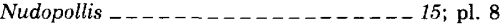
endocuspis, Pseudoplicapollis _...... Endoinfundibulapollis _..._. distinctus _. eximius, Choanopollenites _expolitus, Thomsonipollis __________ pl. 16 Extrapollis Extratriporopollenites
Extratriporopollenites - Con.

endangulatus

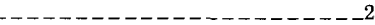

terminalis _..-

Extremipollis _........... $9,11,34,37$ caminus _._._.

maastrichtiensis

versatilis

$10 ;$ pl. 2

vivus

9,$10 ;$ pl. 2

F, G, H

Fossil pollen, sample localities ____.___-__-_ 3 type specimens _._. funiculus, Complexiopollis _..._. gracilis, Thomsonipollis

hastaformis, Nudopollis terminalis hebeformis, Nudopollis terminalis

(1)

Interpollis _. $11,35,37$ intranodus _._. microsupplingensis _..._. supplingensis _ $\ldots \ldots \ldots \ldots \ldots \ldots 11,12$; pl. 4

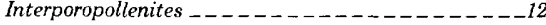
proporus turgidus intraconcavus, Pseudovacuopollis intranodus, Interpollis _._. Intratriporopollenites supplingensis _ _._. involutus, Pseudovacuopollis _...... 23; pl. 14

\section{$\mathrm{K}, \mathrm{L}$}

Kyandopollenites _-_anneratus _. Latipollis _Longanulipollis

maastrichtiensis, Extremipollis

magnificoides, Thomsonipollis magnificus, Thomsonipollis meekeri. Trudopollis _Megatriopollis _. santonius _._. sp. meridium. Nudopollis thiergartii microsupplingensis, Interpollis microverrucatus, Complexiopollis ___ _._. minimus, Minorpollis Minorpollis _Minorpollis minimus _. minutus, Nudopollis thiergartii _._.

Semioculopollis _._._._._._._. Montanapollis _munitus, Vacuopollis

\section{$\mathrm{N}$}

Neotriangulipollis 2,30
Page

New genus A _.

New genus B _._.

New genus $\mathrm{C} \ldots \ldots \ldots \ldots$

New genus D nonperfectus, Trudopollis Normapolles genera, Mississippi embayment, key _ _ 33 stratigraphic distribution _._._. Normapolles species, stratigraphic distribution $\ldots . .37$ Nudopollis _._._. endangulatus _. terminalis _._. hastaformis thiergartii _-_. conspicuus _._. meridium minutus

$\mathrm{O}$

obscurocostatus, Basopollis_--_---_-- _- 8 ; pl. 1 ornatus, Basopollis _orthobasalis, Basopollis __._._._. orthopyramis, Vacuopollis ______ Osculapollis _. aequalis perspectus ___________ 29,$30 ; \mathrm{pl} .18$ sp. A _ _ Oculopollis _._. concentus

$P$

palaeocaenicus, Pseudoplicapollis ____._- 21, 22 Papillopollis _._._._-___-_-_-_-_13 patricius, Choanopollenites _._-_._. patulus. Complexiopollis _._____ Pecakipollis _.

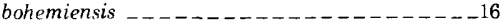
sp. _percentus, Vacuopollis _-_perspectus, Osculapollis pertrudens, Extratriporopollenites _ _ _ _ _ _ -25 Trudopollis _._. plebius, Praecursipollis ___-_-_-_-_- 30; pI. 19 plenus, Trudopollis _Plicapollis _._._._._._._. 2, 7, 17, 34, 35 retusus _. rusticus _._._. serta usitatus _._. vacuus _-

Pompeckjoidaepollenites _._-_-_- 19, 25, 34, 35 subhercynicus _-_-_-_praeatumescens, Complexiopollis _._.

Praebasopollis _._._.

Praecursipollis plebius _-_

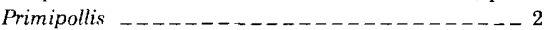
proparuus, Trudopollis ______. proporus, Interporopollenites _._._Proteacidites _._sp. __. _ _ _ _ _ Pseudatlantopollis _._._._._____ $30,34,35,37$ simulatus ____._._._._. 30,$31 ;$ pl. 19

Pseudoculopollis _._._._._. 20 admirabilis 
Page

Pseudoculopollis - Con

sp. A _... Pseudoplicapollis _........... 2, 21, 22, 34, 35

concentricoides -

endrcuspis....

palceocaenicus _..._............ 21. 22

pscudospurites _...

serenus _._.

sp. A _._.

pseudesporites, Pseudoplicapollis

Pseudinacuopollis _._.___________. 23. 34

intraconcavus _............... 23, 24

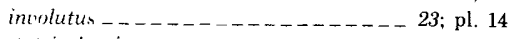

Punctatricolporites

Q, R

Quedlinburgipollis _................... 2

rector. Trudopollis _..._.

reticulatus, Atlantopollis _............

retusus. Plicapollis

rusticus, Plicapollis

18,$19 ;$ pl. 10

$\mathrm{S}$

Sample localities, fossil pollen

Santonipollis

santonius, Megatriopollis
Page

Semioculopollis

minutus

sp. A _

serenus, Pseudoplicapollis _._._._. 22; pl. 13

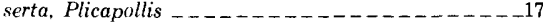

Siberiapollis _.

simulatus, Pseudatlantopollis _._- 30,$31 ;$ pl. 19

Sporopollis _._.

Stratigraphic distribution. Normapolles genera

Normapolles species _._.

subhercynicus, Pompeckjoidaepollenites _-_ 19; pl. 11

supplingensis, Interpollis _-_-_.

Intratriporopollenites _ _ _ _ _ _ _ _ - 11

Systematic descriptions _...

\section{$\mathrm{T}$}

terminalis, Extratriporopollenites

Nudopollis _. hastaformis ................... 15

hebeformis

thiergartii, Nudopollis

Nudopollis conspicuus _._. meridium _.

minutus _...

Thomsonipollis _._._. expolitus _..gracilis _._. magnificoides _........... 3,$24 ; \mathrm{pl} .15$ magnificus _.
Page

transitus, Choanopollenites _._.

Triangulipollis _.

Triatriopollenites _._._._.

Trudopollis _... artifex _.

meekeri _._.

nonperfectus _................

pertrudens

plenus _................ 26; pl. 17

proparuus _.

rector

subhercynicus _...

variabilis _...

sp. A _...

sp. B

sp. C $-\ldots-\ldots-\ldots-\ldots-17$

turgidus, Interporopollenites

Turonipollis -

Type specimens, fossil pollens _._.

\section{$\mathrm{U}, \mathrm{V}$}

usitatus, Plicapollis _ Vacuopollis _... munitus _._._.

orthopyramis _._.

percentus _.

vacuus, Plicapollis variabilis, Trudopollis__._._.

versatilis, Extremipollis _..._._.

vivus, Extremipollis _._. 


\section{PLATES 1-20}

[Contact photographs of the plates in this report are available, at cost, from the U.S. Geological Survey Photographic Library, Federal Center, Denver, Colorado 80225] 


\section{PLATE 1}

[Magnification $\times 1,000$ unless otherwise indicated]

Figures 1-12. Basopollis obscurocostatus, n. sp.

1-3. Holotype, sample D1862, slide 3, preparation 2, coordinates $95.7 \times 3.9$, diameter $29 \mu$.

3. Holotype $\times 2,000$.

4-7. Paratype, sample D1862, slide 3, preparation 2, coordinates $92.6 \times 16.1$, diameter $42 \mu$.

8-10. Sample D1851, slide 3, coordinates $107.0 \times 4$.4, diameter $29 \mu$.

10. Same $\times 2,000$.

11-12. Sample D1862, slide 3, preparation 2, coordinates $105.6 \times 13.3$, diameter $29 \mu$.

13-15. Cf. Choanopollenites sp.

13. Sample D3138, slide 4, coordinates $88.5 \times 13.2$, diameter $26 \mu, \times 2,000$.

14-15. Same $\times 1,000$. 

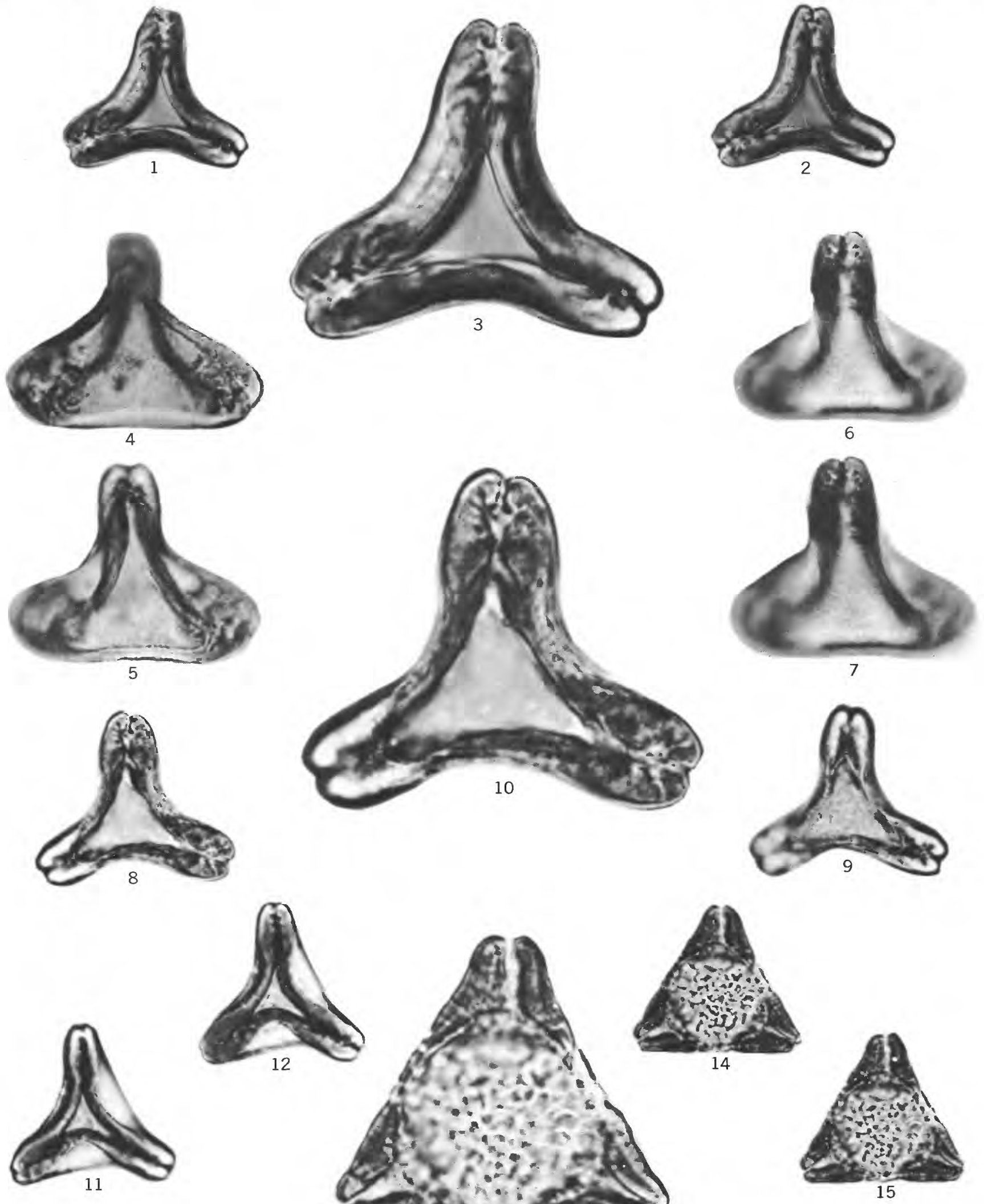

BASOPOLLIS OBSCUROCOSTATUS AND CF. CHOANOPOLLENITES SP. 


\section{PLATE 2}

[Magnification $\times 1,000$ unless otherwise indicated]

Figures 1-10, Extremipollis vivus, n. sp.

$1-5,8$. Holotype, sample D3420, slide 2, coordinates $95.2 \times 21.0$, diameter $23 \mu$.

8. Holotype $\times 2,000$.

6-7. Paratype, sample D3420, slide 4, coordinates $94.4 \times 21.0$, diameter $27 \mu$.

9-10. Sample D 3420 , slide 2, coordinates $94.8 \times 7.8$, diameter $23 \mu$. A specimen with somewhat shorter annuli and more equilateral triangular shape.

11-22. Extremipollis versatilis, $\mathrm{n} . \mathrm{sp}$.

11-15. Holotype, sample D3420, slide 3, coordinates $97.6 \times 11.5$, diameter $27 \mu$.

15. Holotype $\times 2,000$.

16-17. Paratype, sample D3420, slide 3, coordinates $108.2 \times 5.3$, diameter $27 \mu$.

18-19. Sample D3420, slide 2, coordinates $99.0 \times 10.0$, diameter $26 \mu$.

20-22. Sample D4268-A, slide 1, coordinates $88.1 \times 15.3$, diameter $30 \mu$. May be a variety or different species with thinner ektexine, provisionally including it here. 
GEOLOGICAL SURVEY

PROFESSIONAL PAPER 865 PLATE 2
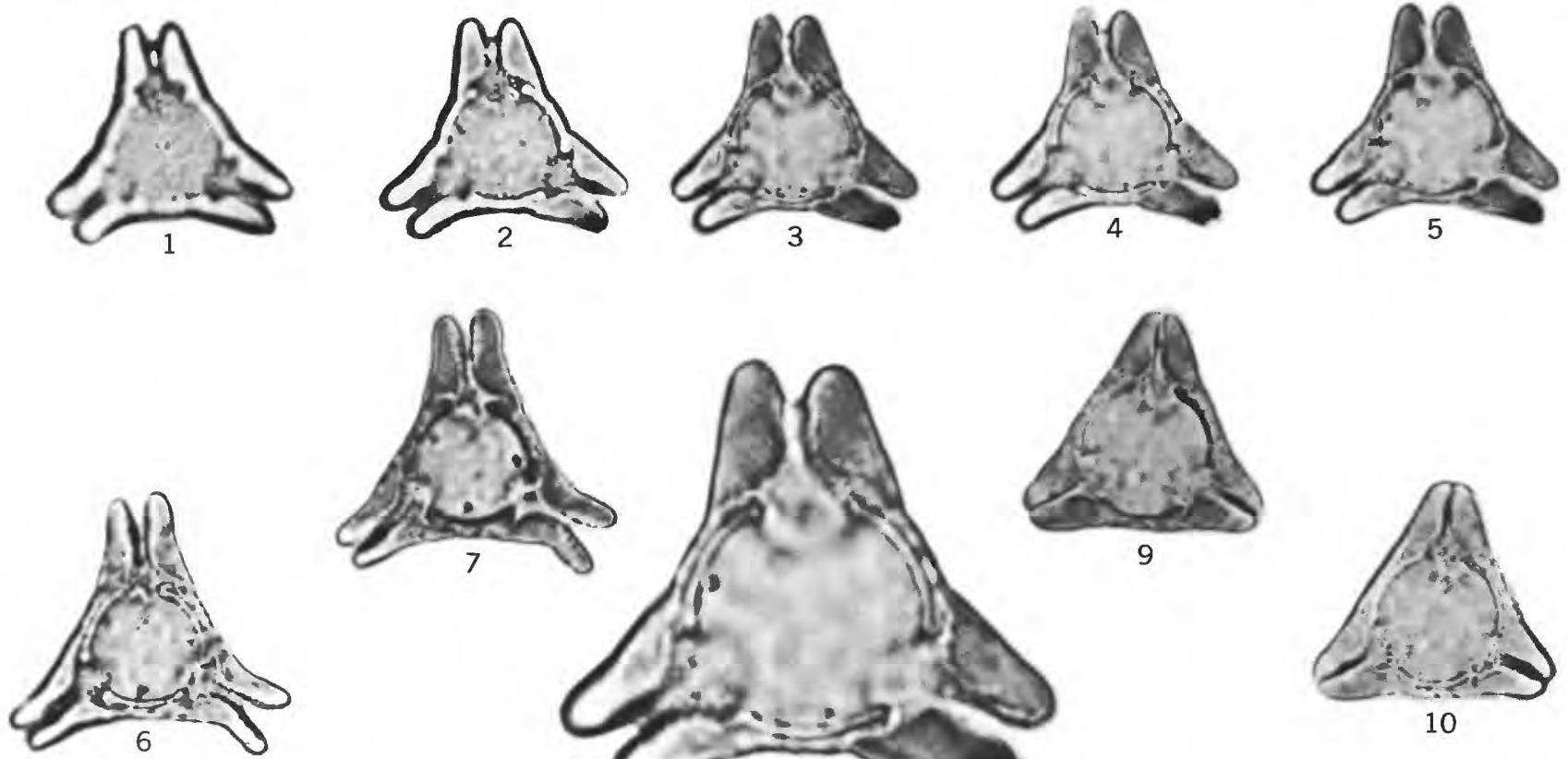

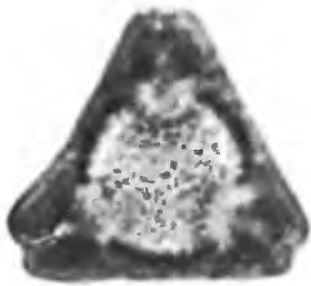

11

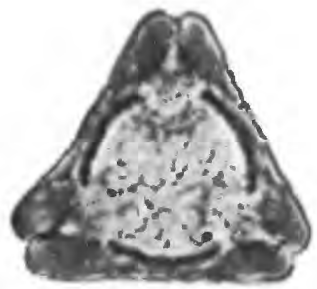

12

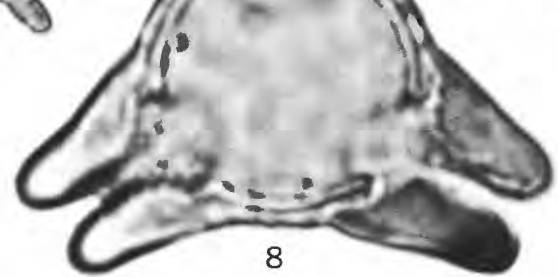

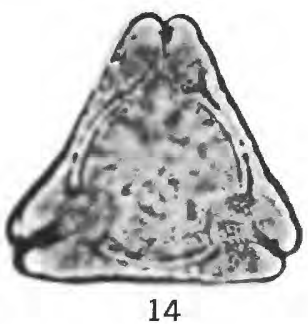

13
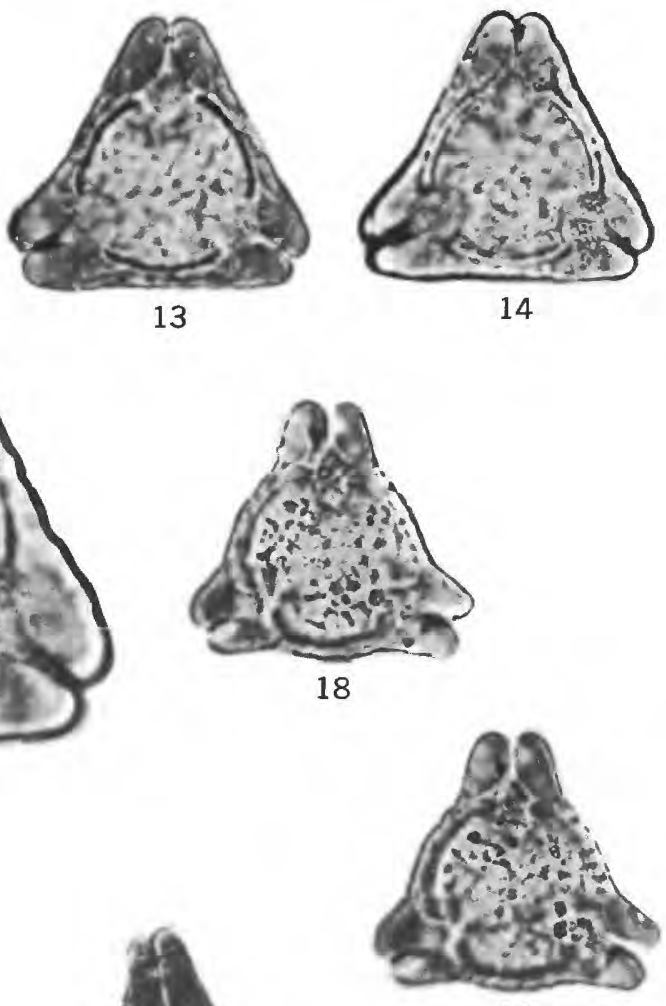

19
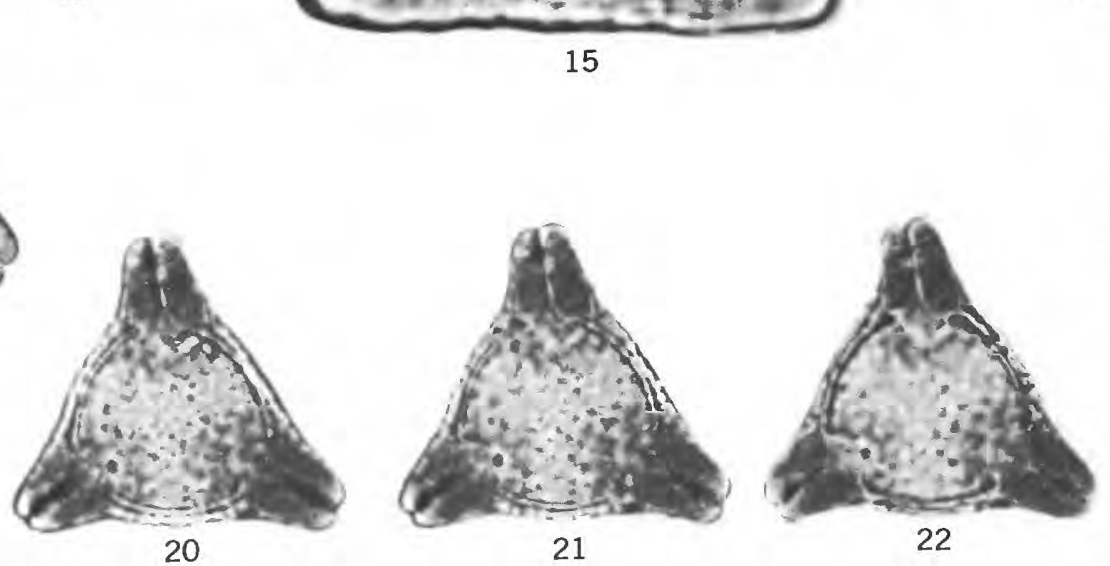

EXTREMIPOLLIS VIVUS AND E. VERSATILIS 


\section{PLATE 3}

[Magnification $\times 1,000$ unless otherwise indicated]

Figures 1-18. Extremipollis caminus, n. sp.

1-5. Holotype, sample D3420, slide 4, coordinates $79.7 \times 4.5$, diameter $36 \mu$.

5. Holotype $\times 2,000$.

6-7. Paratype, sample D3420, slide 2, coordinates $84.3 \times 14.8$, diameter $32 \mu$.

8-9. Sample D3413, slide 3, coordinates $104.0 \times 12.0$, diameter $41 \mu$.

10. Sample D3420, slide 3, coordinates $82.0 \times 13.4$, diameter $31 \mu$.

11-12. Sample D3420, slide 5, coordinates $112.1 \times 10.2$, diameter $36 \mu$.

13. Sample D3420, slide 3, coordinates $79.5 \times 20.7$, diameter $32 \mu$.

14-18. Sample D3420, slide 2, coordinates $104.2 \times 14.5$, diameter $25 \mu$. 
GEOLOGICAL SURVEY
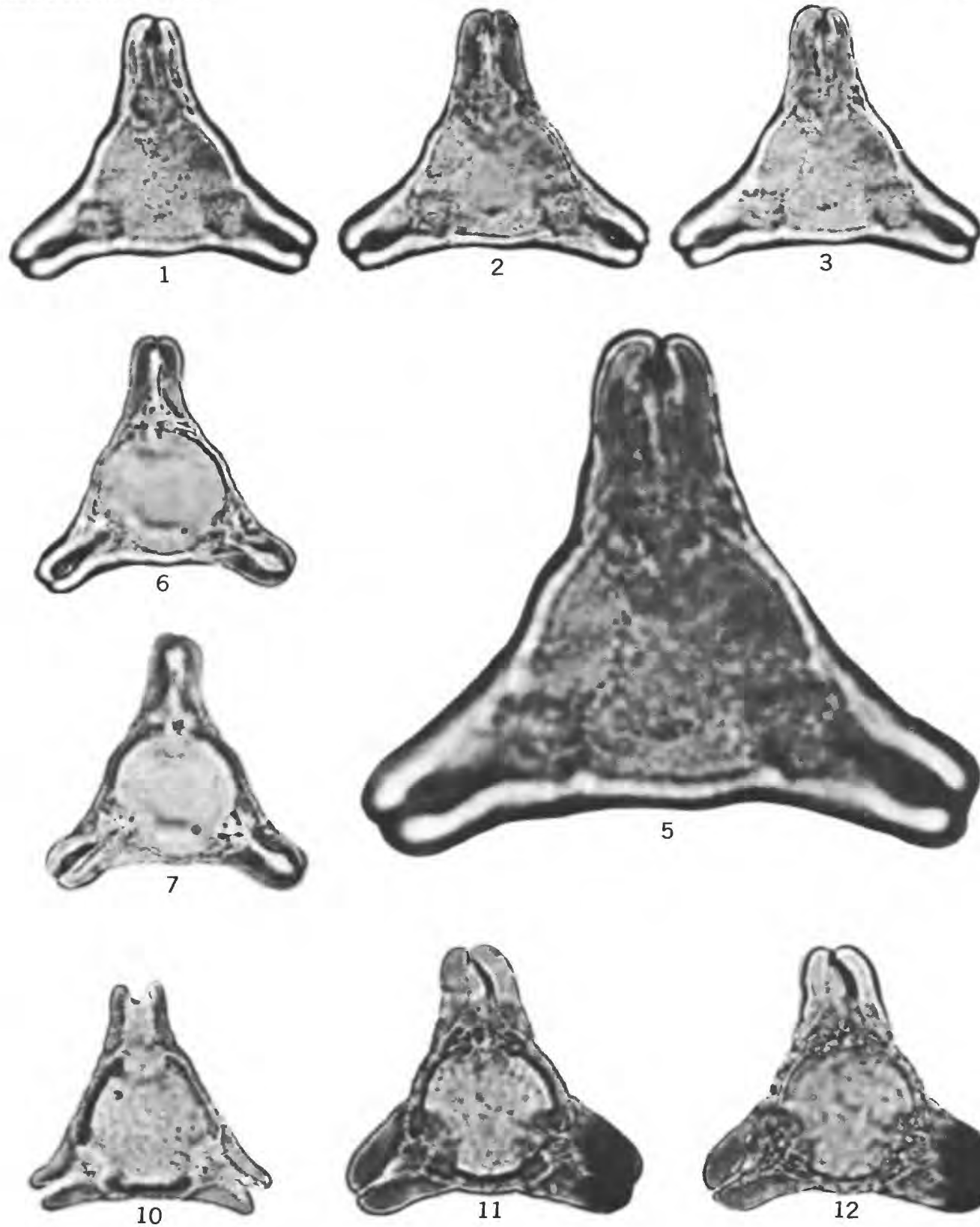
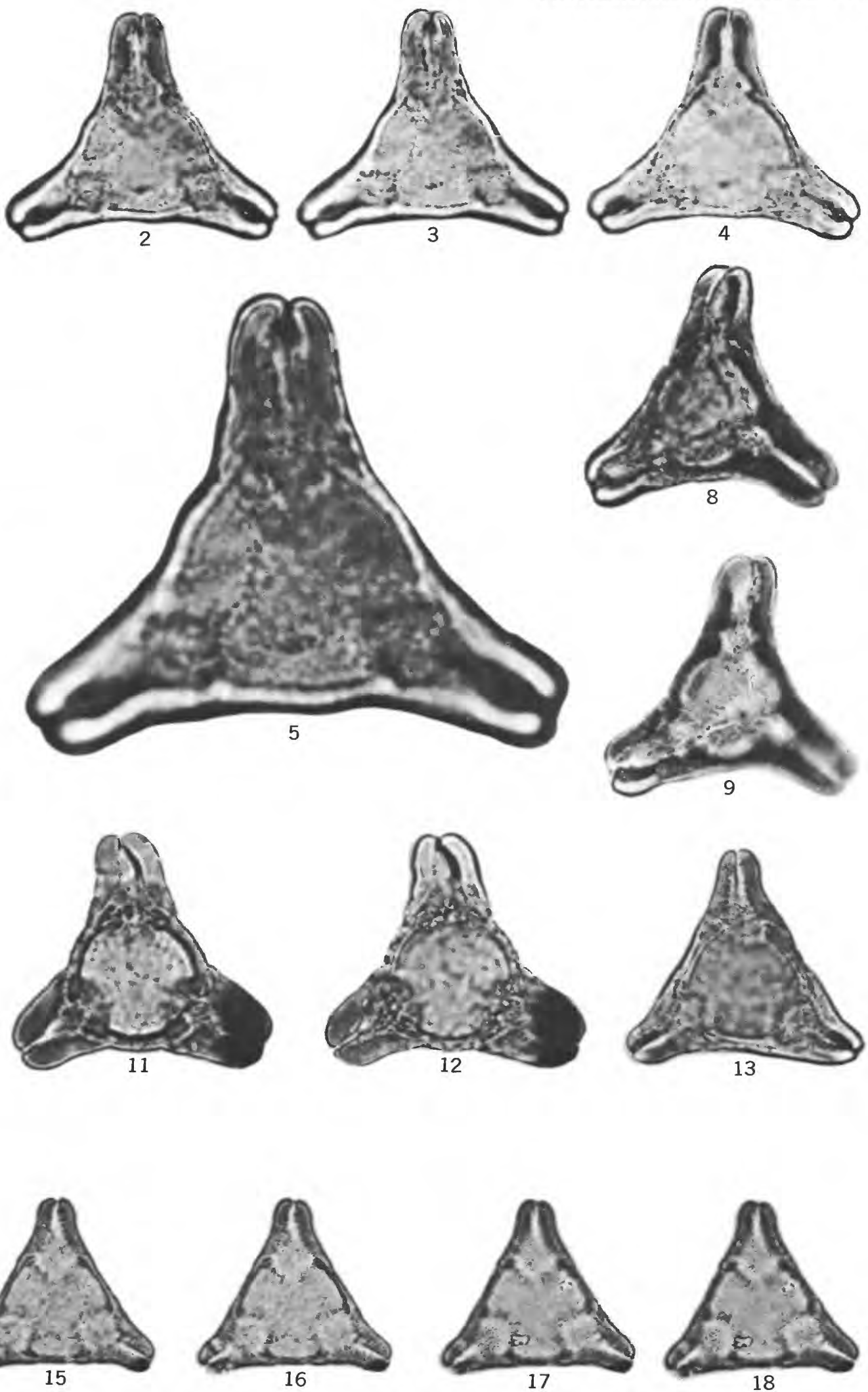


\section{PLATE 4}

[Magnification $\times 1,000$ unless otherwise indicated]

FIGURES 1-21. Internollis of $I$ sunnlingensis

1-3. Sample D3410-C, slide 4, coordinates $76.4 \times 21.1$, diameter $28 \mu$.

3 . Same $\times 2,000$.

4-5. Sample D3410-C, slide 3, coordinates $101.9 \times 4.4$, diameter $26 \mu$.

4. One external pore (at top) subequatorial; another, equatorial. Bacula below ektexine gives appearance of rough surface.

6-8. Sample D3410-C, slide 5, preparation 3, coordinates $106.5 \times 22.6$, diameter $25 \mu$. Equatorial constriction shows clearly, as well as absence of bacula in polar regions.

9-13. Sample 1967-A, slide 1, coordinates $81.9 \times 13.5$, diameter $23 \mu$.

14-15. Sample D3413, slide 2, coordinates $93.3 \times 3.5$, diameter $28 \mu$. A variant with prominent thickening around endogerminal and slightly larger size.

16-18. Sample D1967-A, slide 1, coordinates $93.3 \times 2.2$, diameter $20 \mu$. Equatorial constriction shows well.

19-21. Sample D3260, slide 8 , coordinates $80.4 \times 14.5$, diameter $16 \mu$, a smaller variety.

22-25. Interpollis microsupplingenis.

22-23. Sample D1855, slide 6, preparation 2, coordinates $82.3 \times 12.9$, diameter $20 \mu$.

24-25. Sample D1848, slide 3 , coordinates $88.1 \times 13.4$, diameter $20 \mu$. 
GEOLOGICAL SURVEY
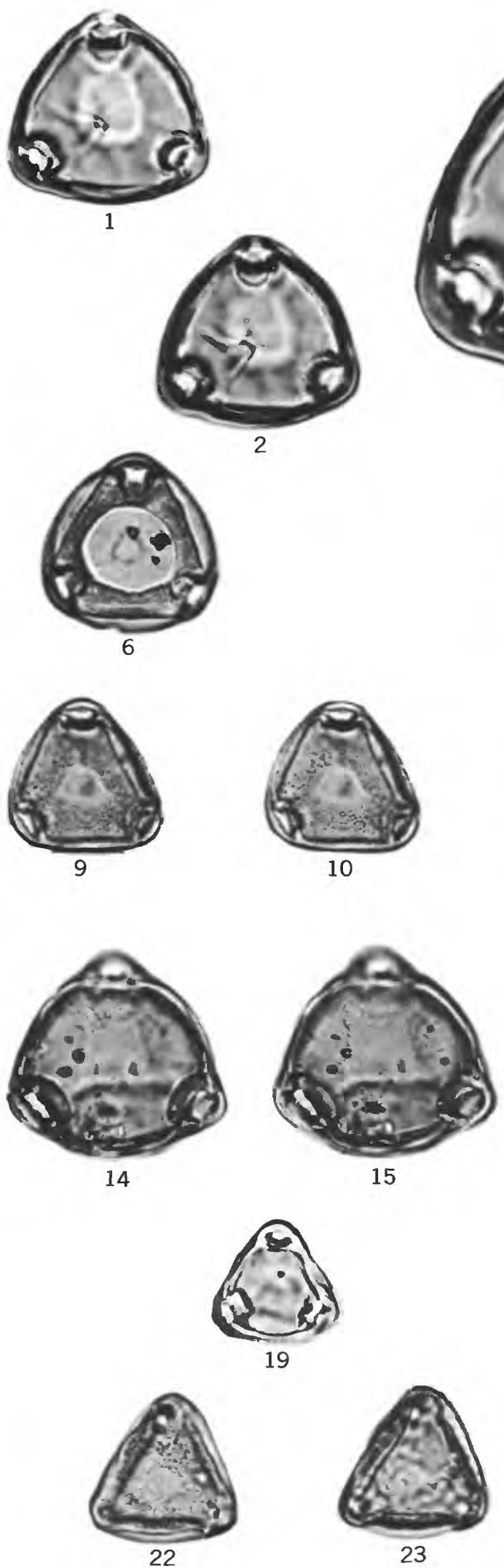

PROFESSIONAL PAPER 865 PLATE 4
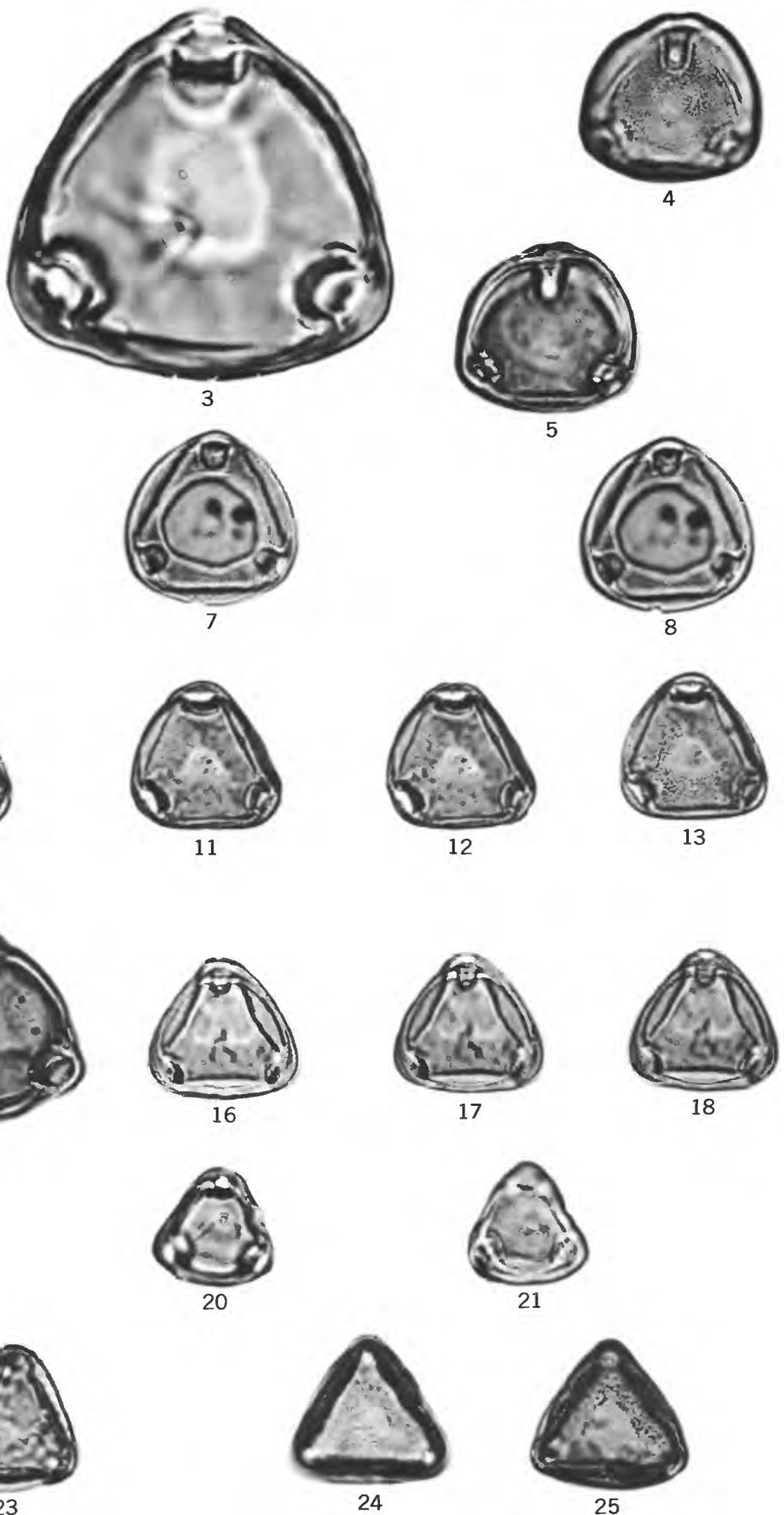


\section{PLATE 5}

[Magnification $\times 1,000$ unless otherwise indicated]

FiguREs 1-15. Interpollis intranodus, n. sp.

1-5. Holotype, sample D3285, slide 1 , coordinates $90.3 \times 15.3$, diameter $25 \mu$.

1. Shows nodelike gemmae between ektexine and endexine appearing as black dots.

5. Holotype $\times 2,000$.

6-7. Paratype, sample D3285, slide 2, coordinates $97.7 \times 21.7$, diameter $25 \mu$.

8-9. Sample D1966-C, slide 2, coordinates $103.8 \times 11.6$, diameter $28 \mu$.

10. Same $\times 2,000$. Note circular subequatorial pore in upper aperture.

11-12. Sample D1966-F, slide 14, coordinates $80.5 \times 22.5$, diameter $25 \mu$.

13-14. Sample D3413, slide 3, coordinates $94.7 \times 7.6$, diameter $36 \mu$. A slightly larger variety.

15. Same $\times 2,000$. Interloculum shows well on this specimen. 


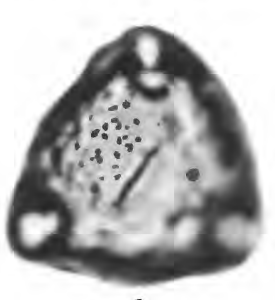

1

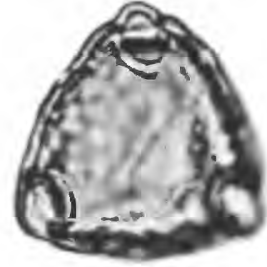

2
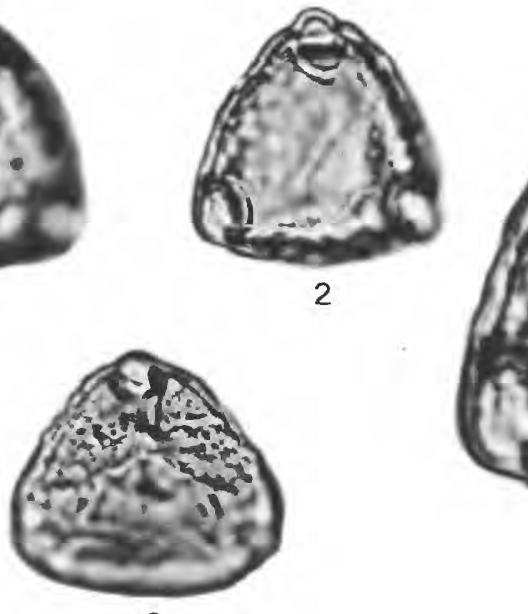

6
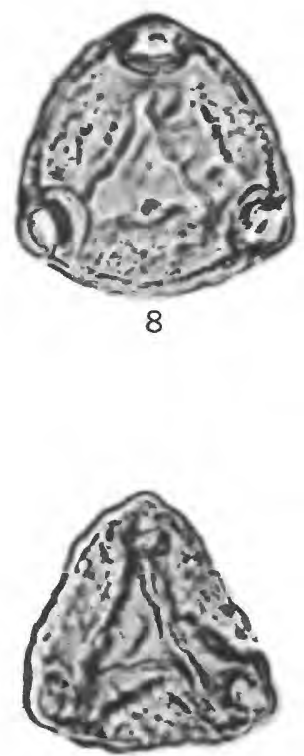

11

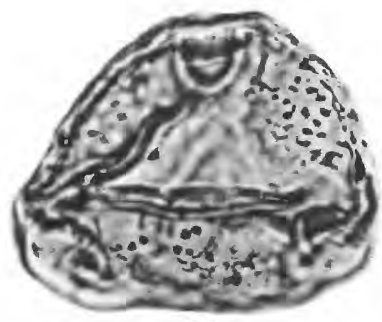

13

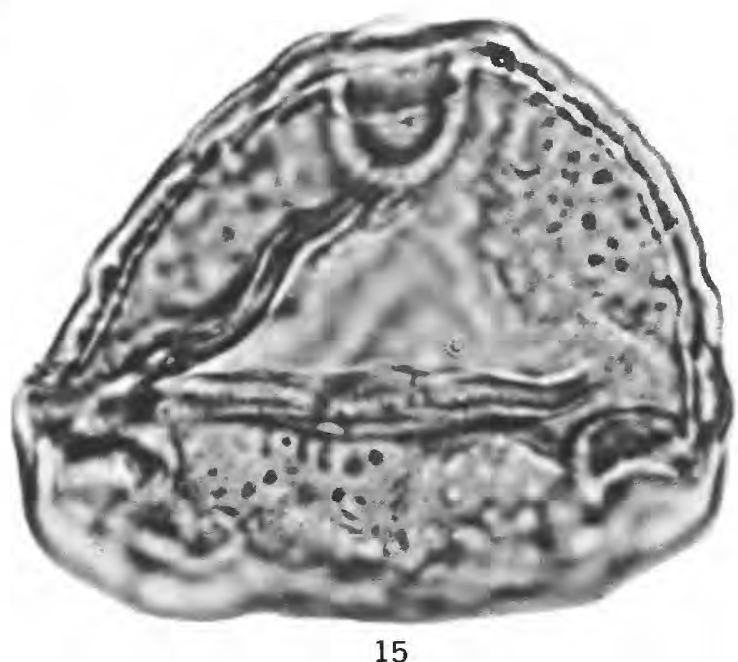

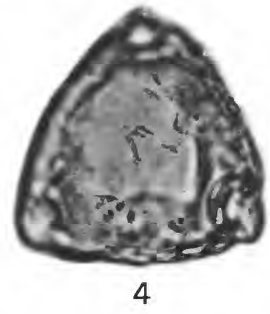
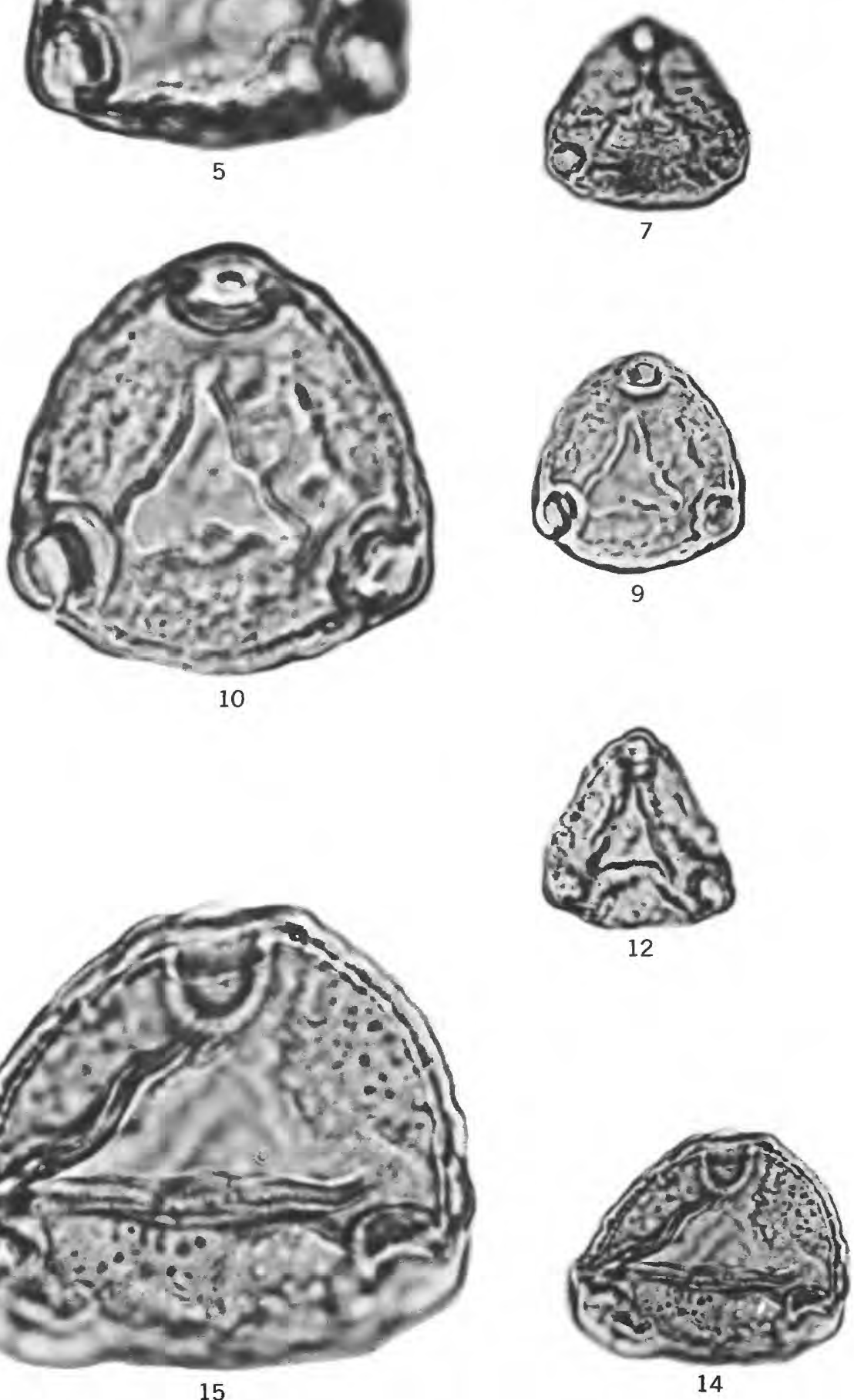


\section{PLATE 6}

[Magnification $\times 1,000$ unless otherwise indicated]

FiguRES 1-18. Interporopollenites turgidus, n. sp.

1-6. Holotype, sample D3548-A, slide 1 , coordinates $77.5 \times 11.8$, diameter $26 \mu$. Photographs at different focal levels.

6. $\times 2,000$.

7-8. Sample D3285, slide 2, coordinates $92.1 \times 3.9$, diameter $24 \mu$.

9-12. Paratype, sample D3548-A, slide 2 , coordinates $78.4 \times 6.5$, diameter $29 \mu$.

13-15. Sample D3285, slide 1, coordinates $83.6 \times 14.9$, diameter $25 \mu$. Note thin polar spots on this and succeeding specimens.

16-18. Sample D3548-A, slide 2, coordinates $84.1 \times 11.0$, diameter $26 \mu$. 

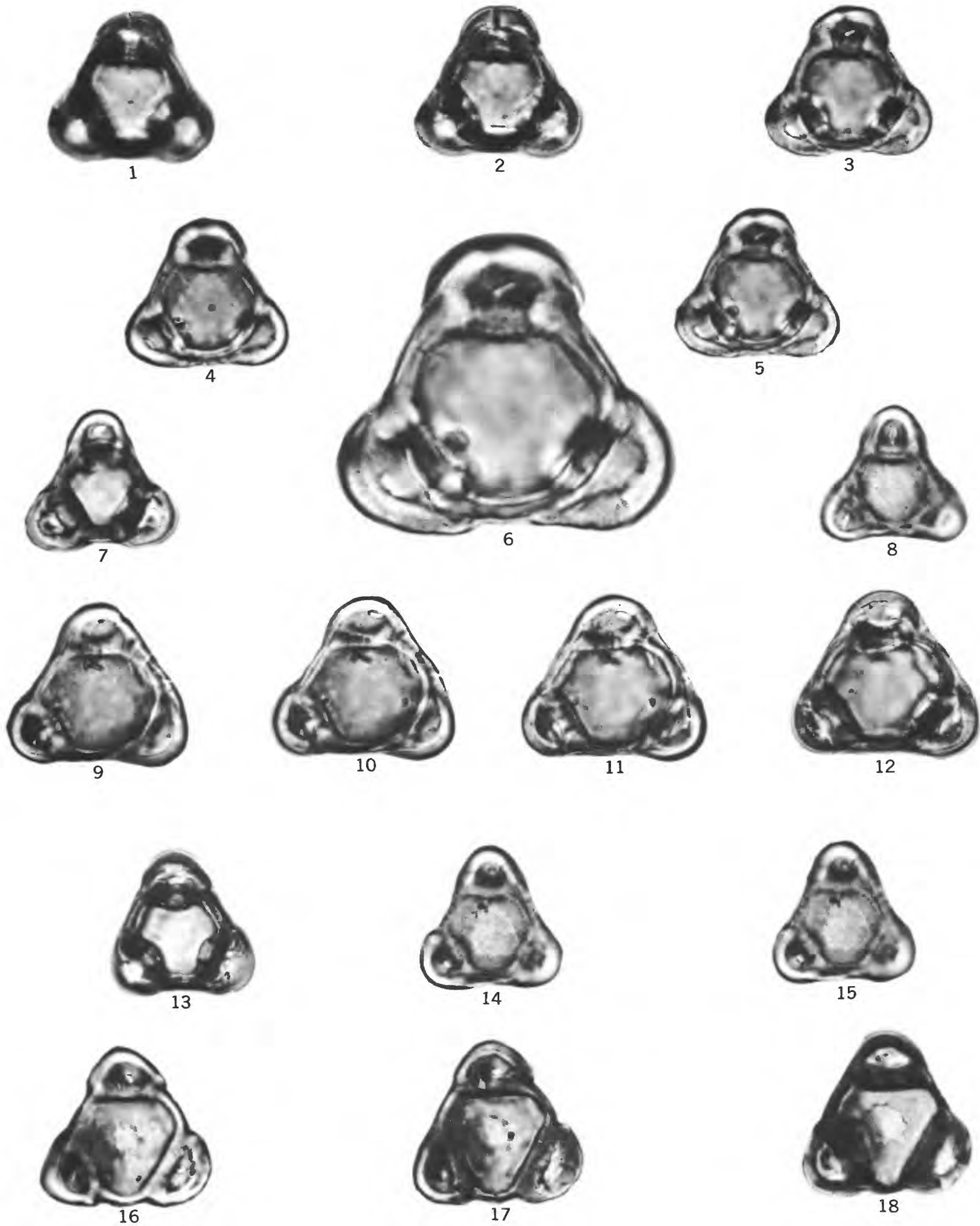


\section{PLATE 7}

[Magnification $\times 1,000$ unless otherwise indicated]

Figures 1-5. Kyandopollenites anneratus Stover

1. Sample D1862, slide 6, preparation 2, coordinates $101.8 \times 7.1$, diameter $55 \mu$.

2. Same $\times 2,000$, showing wall layers and pores.

$3-5$. Sample D1846, slide 1 , coordinates $102.4 \times 11.8$, diameter $55 \mu$.

3. Surface ornamentation.

4. Intermediate focus.

5. Showing wall layers.

6-10. Megatriopollis? sp.

6-9. Sample D3285, slide 2, coordinates $100.1 \times 7.9$, diameter $29 \mu$.

10. Same $\times 2,000$. 

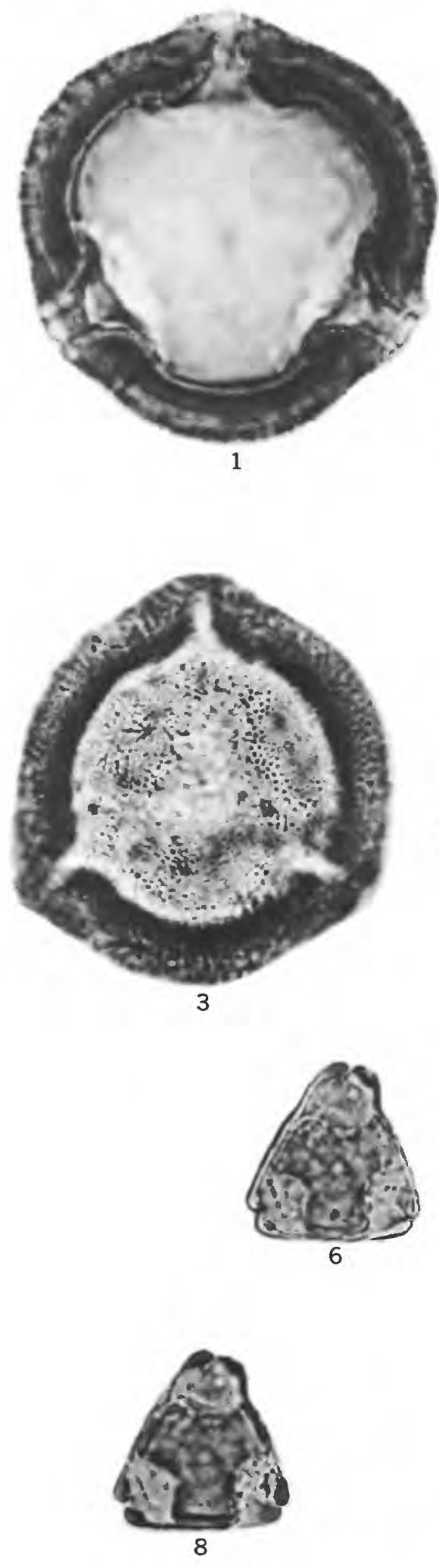
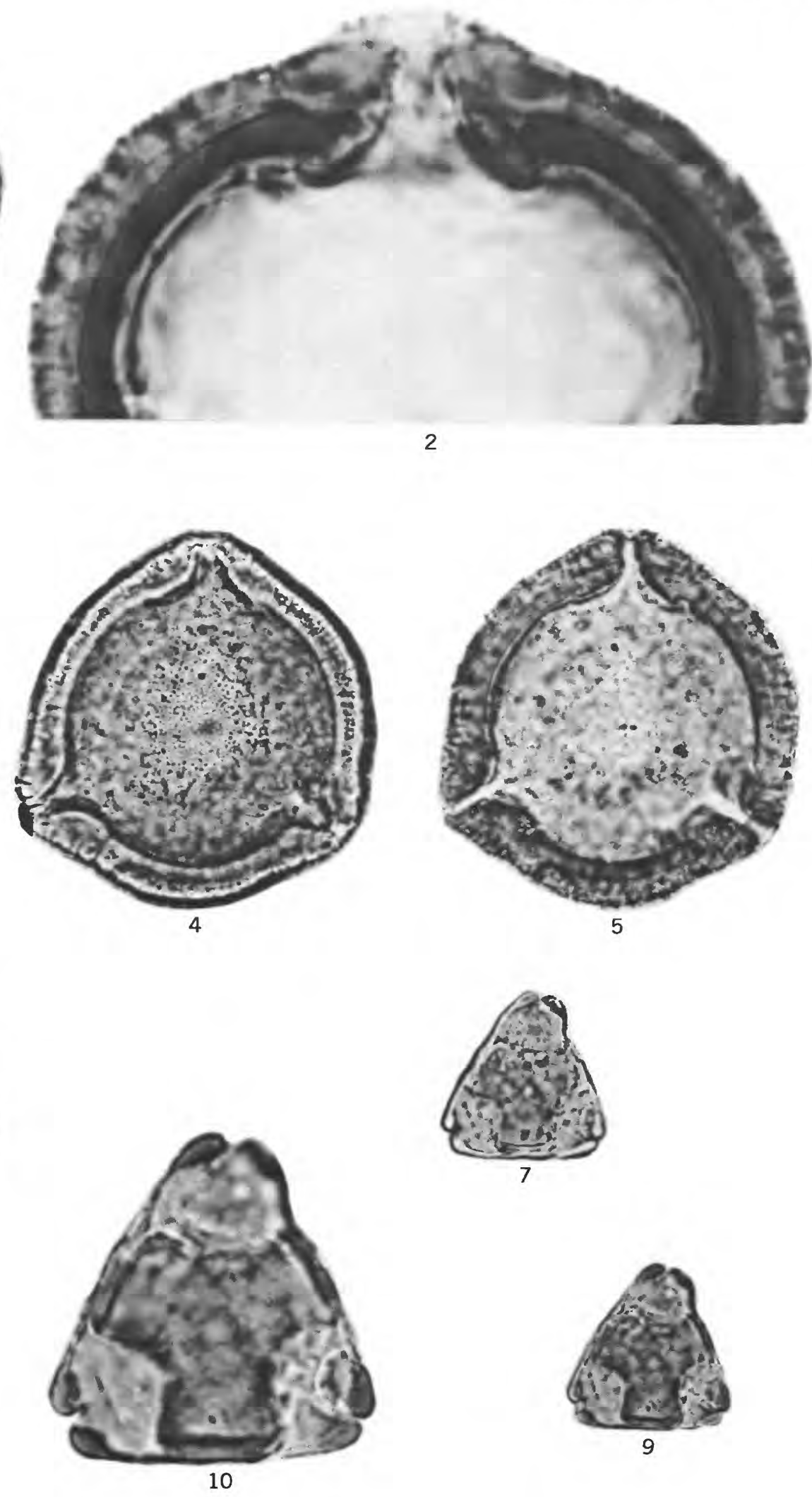

KYANDOPOLLENITES ANNERATUS AND MEGATRIOPOLLIS? SP. 


\section{PLATE 8}

[Magnification $\times 1,000$ unless otherwise indicated]

Figures 1-9. Minorpollis aff. M. minimus

1-5. Sample D3285, slide 1 , coordinates $82.3 \times 6.7$, diameter $15 \mu$.

5. Same $\times 2,000$.

6-7. Sample D1966-F, slide 6, coordinates $76.4 \times 6.9$, diameter $15 \mu$.

8-9. Sample D1966-F, slide 7, coordinates $104.2 \times 4.6$, diameter $16 \mu$.

10-25. Nudopollis

10-11. Nudopollis aff. N. endangulatus

Sample D3222, slide 1, coordinates $107.5 \times 15.3$, diameter $25 \mu$.

12-15. Nudopollis aff. N. thiergartii

12-13. Sample D3416, slide 1 , coordinates $103.3 \times 13.7$, diameter $28 \mu$.

14-15. Sample D3416, slide 2, coordinates $90.3 \times 5.0$, diameter $25 \mu$.

16-25. Nudopollis aff. N. terminalis

16-17. Sample D3222, slide 1, coordinates $79.3 \times 21.0$, diameter $29 \mu$.

18-19. Sample D3548-A, slide 2, coordinates $80.7 \times 9.2$, diameter $28 \mu$.

20-21. Sample D1848, slide 3, coordinates $83.1 \times 13.0$, diamter $33 \mu$.

22-25. Sample D1848, slide 3, coordinates $85.7 \times 18.2$, diameter $36 \mu$. 

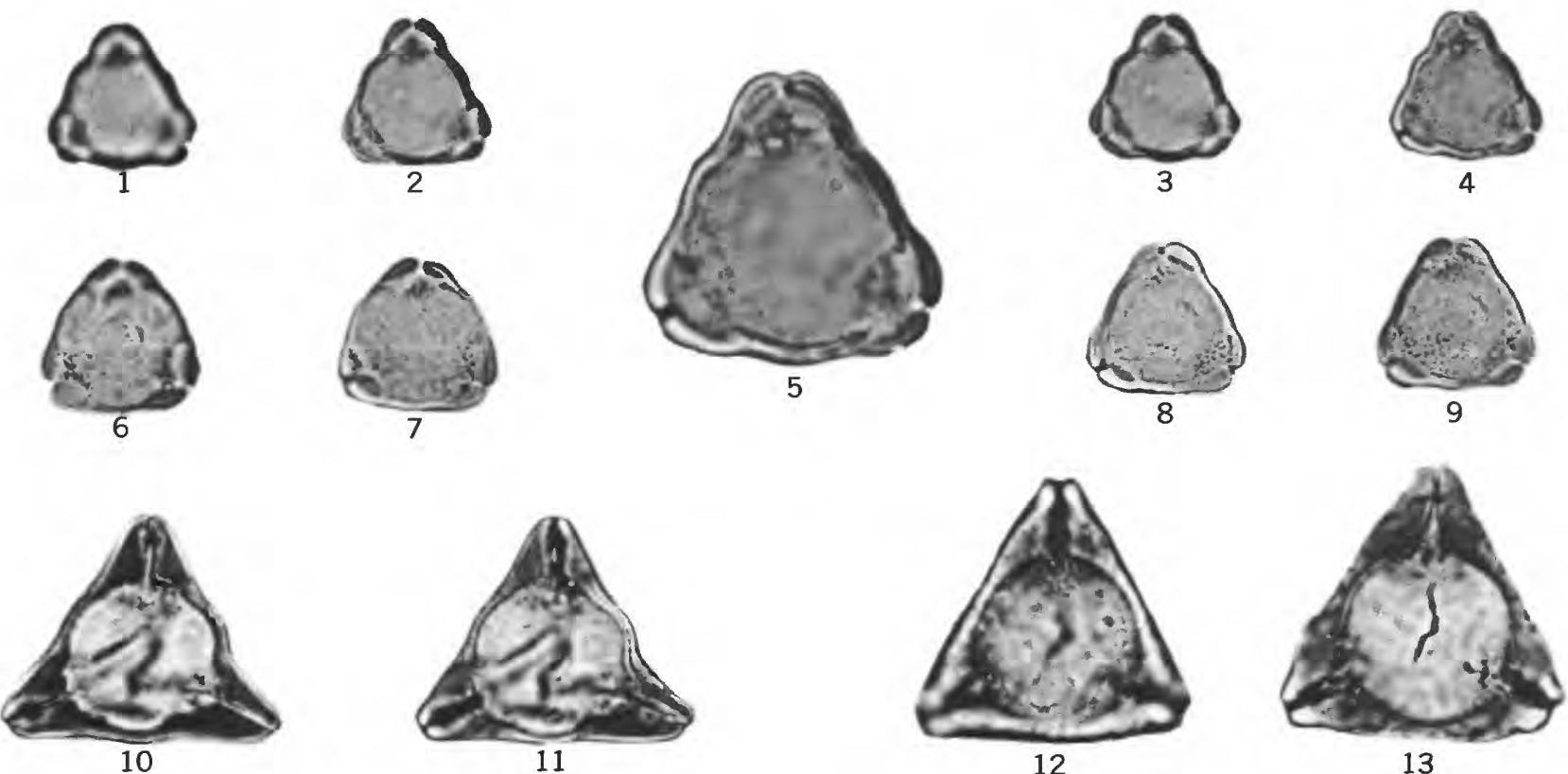

13
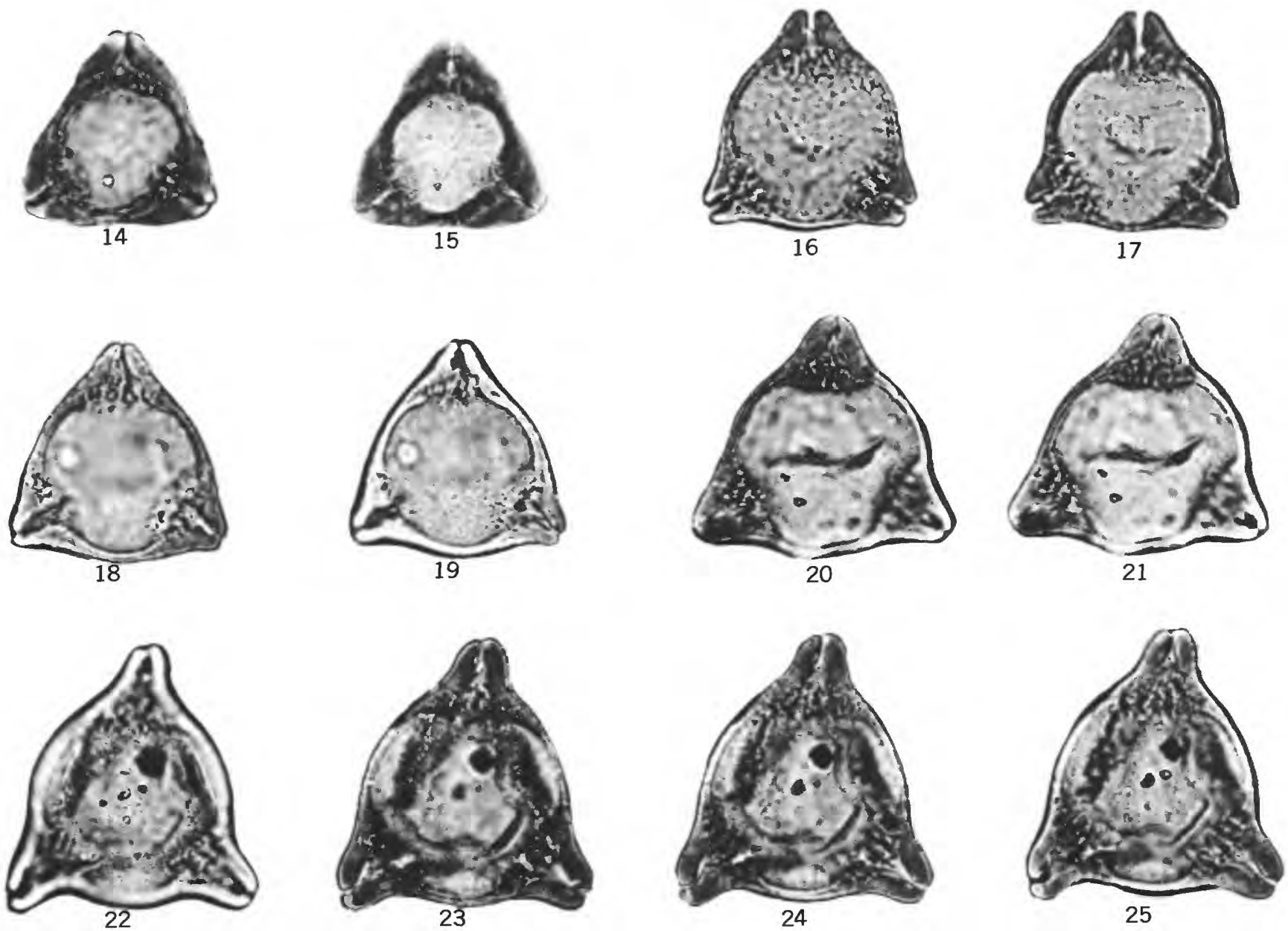

MINORPOLLIS AFF. M. MINIMUS, NUDOPOLLIS AFF. N. ENDANGULATUS,

$N$. AFF. N. THIERGARTII, AND $N$. AFF. N. TERMINALIS 


\section{PLATE 9}

[Magnification $\times 1.000$ unless otherwise indicated]

Figures 1-5. Cf. Pecakipollis sp.

Sample D3413, slide 1, coordinates $90.7 \times 10.1$, diameter $23 \mu$.

1-2. 4-5. Different focal levels.

3. $\times 2,000$

6-14. Plicapollis usitatus, n. sp.

6-8. Holotype, sample D3260, slide 2, coordinates $89.8 \times 10.3$, diameter $20 \mu$.

8. Same $\times 2,000$.

9-10. Paratype, sample D3260, slide 1 , coordinates $110.8 \times 17.7$, diameter $19 \mu$. Note torn lower left aperture. Although exogerminals are clearly pores, this tear provides the appearance of a vertical slit shaped aperture.

11-12. Sample D3413, slide 1, coordinates $111.2 \times 11.4$, diameter $19.5 \mu$.

13-14. Sample D3260, slide 3, coordinates $92.7 \times 18.0$, diameter $20 \mu$.

15-24. Plicapollis retusus, n. sp.

15-19. Holotype, sample D3412, slide 3, coordinates $112.5 \times 2.4$, diameter $26 \mu$.

17. Holotype $\times 2,000$.

20-21. Sample D3413, slide 1, coordinates $82.4 \times 17.7$, diameter $20 \mu$.

22-24. Paratype, sample D3412, slide 4, coordinates $106.0 \times 19.9$, diameter $23 \mu$.

23. Paratype $\times 2,000$. 

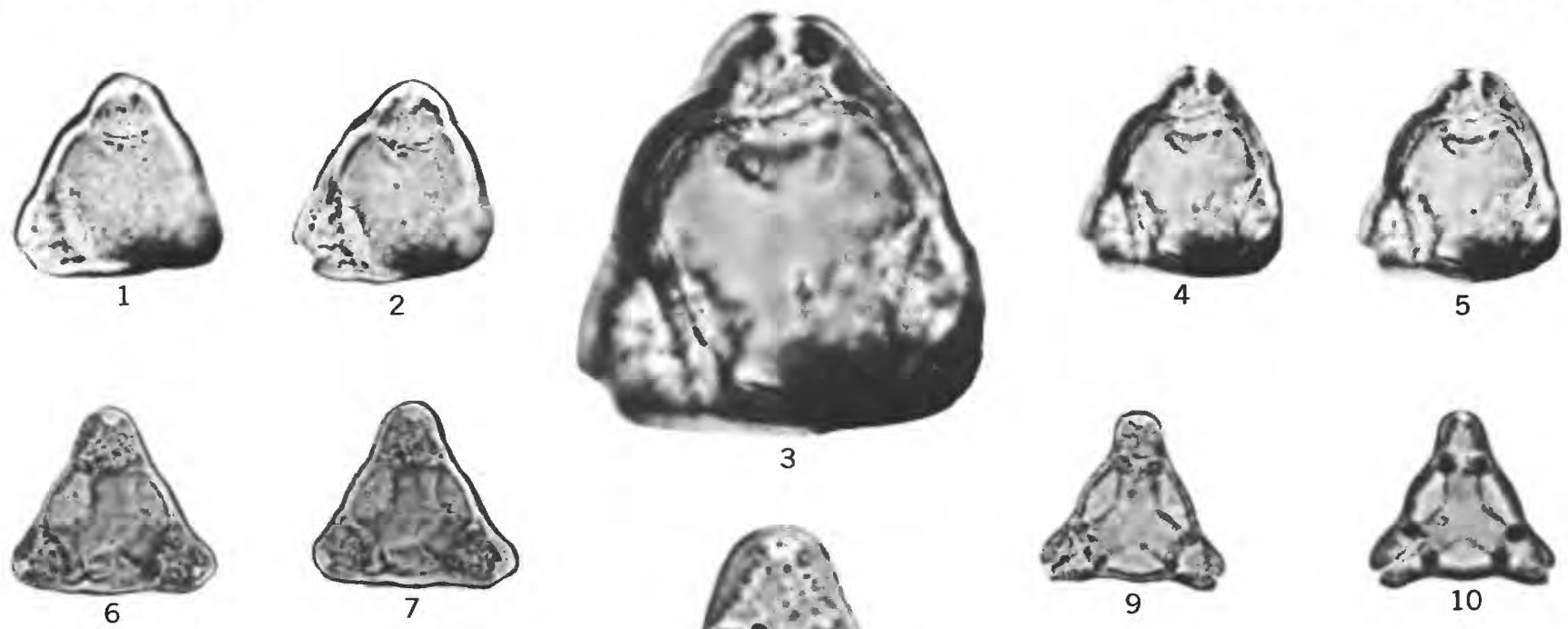

3
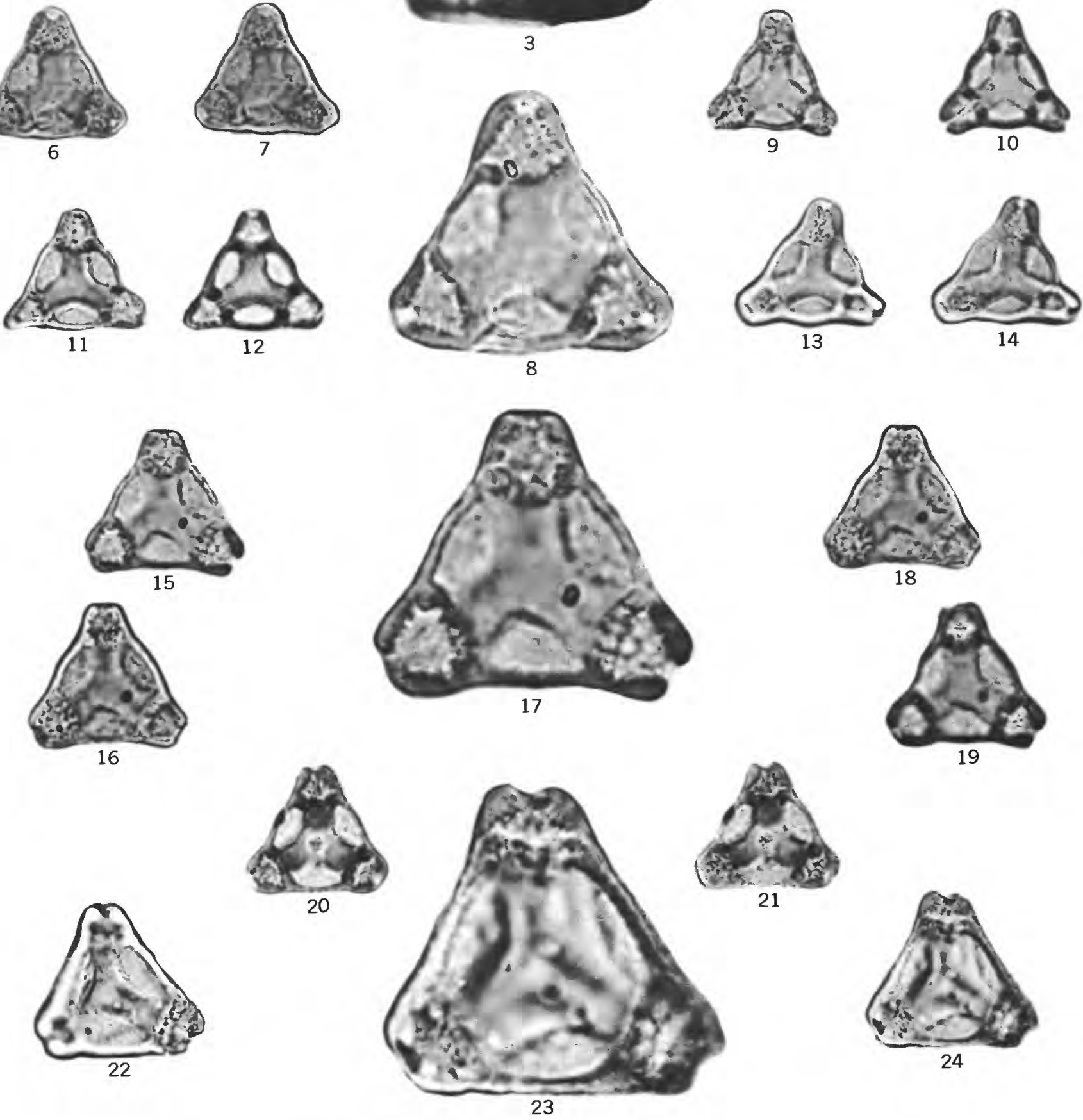

CF. PECAKIPOLLIS SP., PLICAPOLLIS USITATUS, AND PLICAPOLLIS RETUSUS 


\section{PLATE 10}

[Magnification $\times 1,000$ unless otherwise indicated]

Figures 1-9. Plicapollis vacuus, n. sp.

1-5. Holotype, sample D3412, slide 4, coordinates $87.0 \times 3.1$, diameter $21 \mu$.

3. Holotype $\times 2,000$.

6-7. Paratype, sample D3412, slide 1 , coordinates $78.9 \times 17.7$, diameter $18 \mu$.

8-9. Sample D3416, slide 1 , coordinates $108.9 \times 6.9$, diameter $17 \mu$.

10-21. Plicapollis rusticus, n. sp.

10-14. Holotype, sample D3412, slide 4, coordinates $110.9 \times 9.4$, diameter $28 \mu$.

12. Holotype $\times 2,000$.

15-16. Paratype, sample D3412, slide 1, coordinates $108.0 \times 11.8$, diameter $29 \mu$.

17-18. Sample D 3412 , slide 3, coordinates $112.0 \times 5.7$, diameter $23 \mu$.

19-21. Sample D3412, slide 3, coordinates $111.7 \times 2.5$, diameter $25 \mu$.

20. Same $\times 2,000$. 
GEOLOGICAL SURVEY
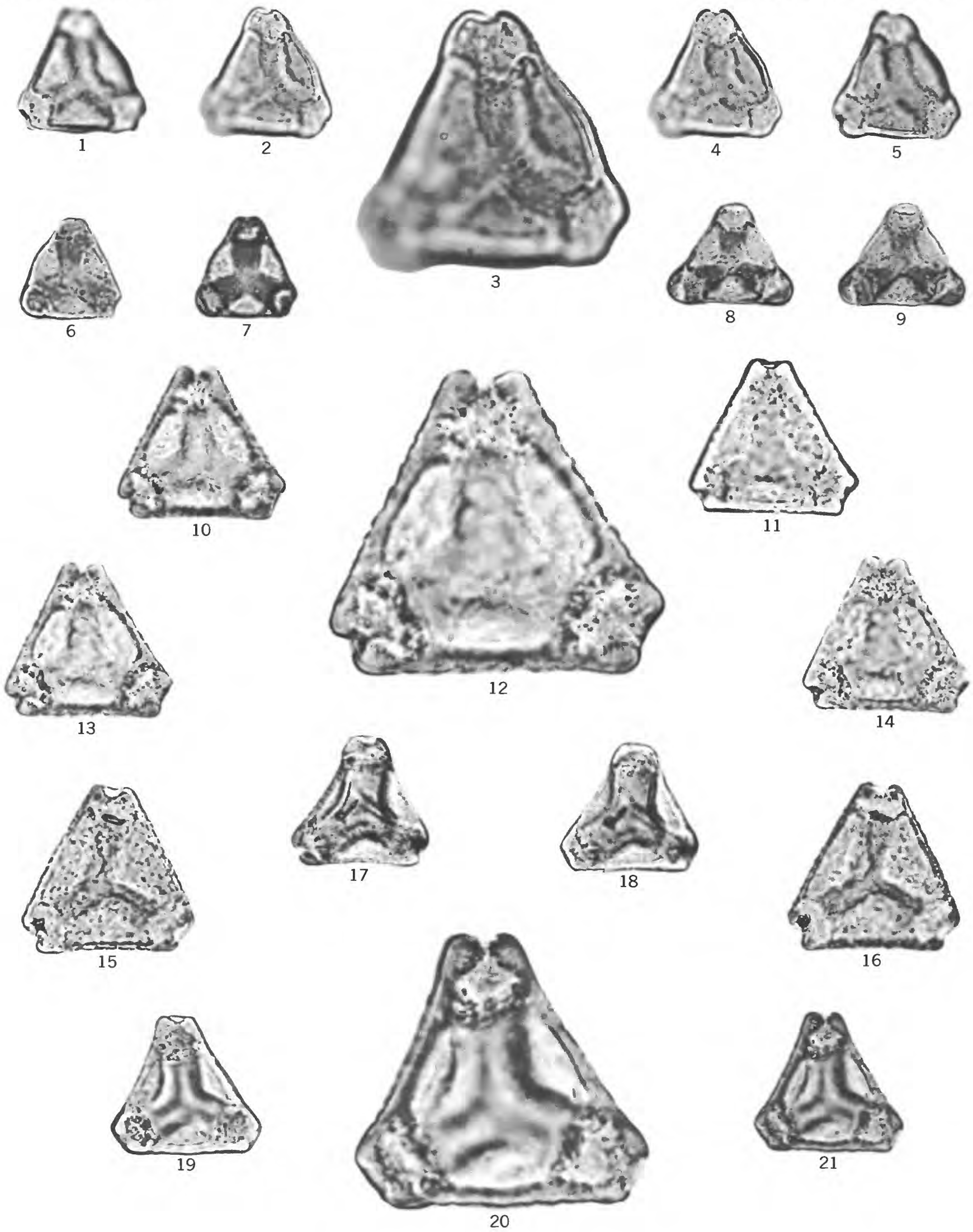

20

PLICAPOLLIS VACUUS AND P. RUSTICUS 


\section{PLATE 11}

[Magnification $\times 1,000$ unless otherwise indicated]

\section{Figures 1-8. Pompeckjoidaepollenites aff. P. subhercynicus}

$1-2$. Sample D1848, slide 3 , coordiantes $82.6 \times 18.4$, diameter $24 \mu$. Note pore and shifted platea.

3-6. Sample D1848, slide 2, coordinates $90.6 \times 2.1$, diameter $23 \mu$. Interloculum visible on figures 5 and 6.

7-8. Sample D1848, slide 2, coordinates $93.9 \times 7.2$, diameter $26 \mu$.

9-18. Pseudoculopollis admirabilis, n. sp.

9-13. Holotype, sample D3420, slide 5 , coordinates $81.5 \times 9.8$, diameter $31 \mu$. Extension of ocular swellings over one pole are on the obverse side of this specimen. Surface ornamentation shown on figures 11, 13.

12. Holotype $\times 2,000$.

14-16. Paratype, sample D 3420 , slide 1 , coordinates $102.3 \times 14.4$, diameter $29 \mu$. Extensions of ocular swelling over pole present on upper surface of this specimen.

17. Sample D3420, slide 1, coordinates $83.0 \times 3.7$, diameter $27 \mu$.

18. Sample D 3420 , slide 4 , coordinates $89.3 \times 16.0$, diameter $30 \mu$. Extensions of ocular swellings present on obverse side of this specimen. 

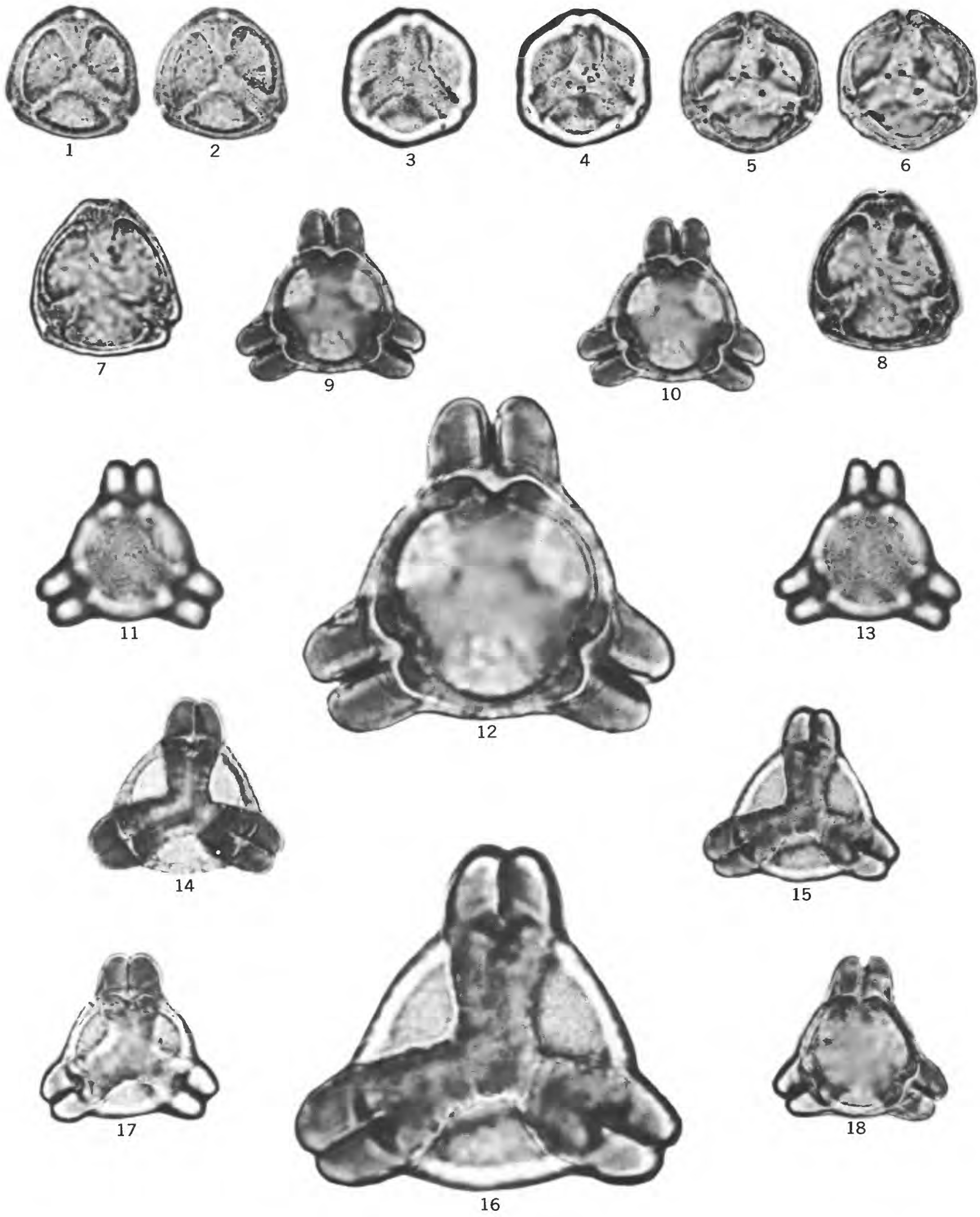


\section{PLATE 12}

[Magnification $\times 1,000$ unless otherwise indicated]

Figures 1-6. Pseudoculopollis sp. A

Sample D3002, slide 3 , coordinates $82.6 \times 2.8$, diameter $36 \mu$.

2. Same $\times 2,000$.

7-13. Semioculopollis sp. A

7-9. Sample D3260, slide 2, coordinates $108.0 \times 4.4$, diameter $25 \mu$.

8. Same $\times 2,000$.

10-13. Sample D3420, slide 5, coordinates $82.8 \times 11.0$, diameter $23 \mu$. 

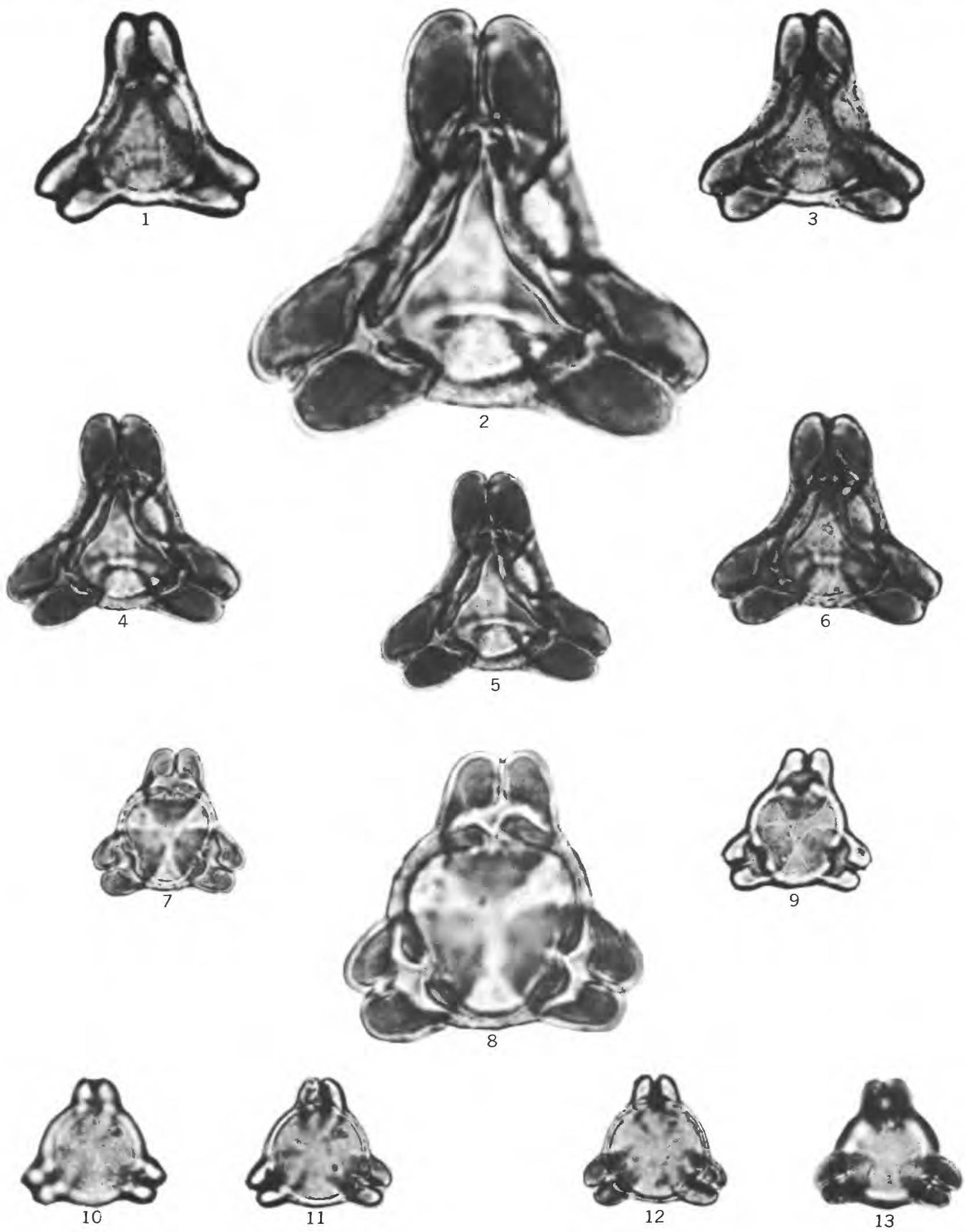
PLATE 13

[Magnification $\times 1,000$ unless otherwise indicated]

Figures 1-7. Pseudoplicapollis endocuspis, n. sp.

1-3. Holotype, sample D3265, slide 1 , coordinates $101.2 \times 6.7$, diameter $18 \mu$.

3. Holotype $\times 2,000$.

4-5. Paratype, sample D3265, slide 3 , coordinates $107.5 \times 9.2$, diameter $22 \mu$.

6-7. Sample D3412, slide 1, coordinates $104.1 \times 17.3$, diameter $16 \mu$.

8-12. Pseudoplicapollis serenus, $\mathrm{n}$. sp.

8-10. Holotype, sample D3412, slide 2, coordinates $84.7 \times 13.0$, diameter $16 \mu$.

10. Holotype $\times 2,000$.

11-12. Paratype, sample D3412, slide 4, coordinates $87.7 \times 6.5$, diameter $16 \mu$. 13-17. Pseudoplicapollis sp. A

13-15. Sample D3222, slide 1, coordinates $101.0 \times 15.7$, diameter $34 \mu$.

15. Same $\times 2,000$

16-17. Sample D1854, slide 3, preparation 2, coordinates $96.1 \times 8.1$, diameter $31 \mu$. 


$$
\begin{aligned}
& -10 \\
& -00
\end{aligned}
$$


PLATE 14

[Magnification $\times 1,000$ unless otherwise indicated]

Figures 1-12. Pseudovacuopollis involutus, n. sp.

1-4. Holotype, sample D3416, slide 2, coordinates $92.9 \times 6.4$, diameter $21 \mu$.

4. Holotype $\times 2,000$.

5. Sample D4268-A, slide 1, coordinates $104.0 \times 2.4$, diameter $20 \mu$.

6. Sample D1967-C, slide 1 , coordinates $103.7 \times 5.0$, diameter $21 \mu$.

7. Sample D4268-A, slide 2, coordinates $74.8 \times 10.3$, diameter $20 \mu$.

8-12. Paratype, sample D3416, slide 2, coordinates $104.7 \times 10.7$, diameter $18 \mu$. The granulate appearance is due to granulation of endexine, ektexine is psilate.

10. Paratype $\times 2,000$.

FIGURES 13-20. Thomsonipollis magnificus Krutzsch

13-14. Sample D1855, slide 3, preparation 2, coordinates $109.9 \times 5.3$, diameter $31 \mu$.

15-16. Sample D1855, slide 6, preparation 2, coordinates $108.5 \times 18.6$, diameter $26 \mu$.

17-20. Sample D1851, slide 3, coordinates $92.4 \times 18.5$, diameter $26 \mu$. Specimen with somewhat thinner endexine somewhat intermediate between Thomsonipollis magnificus and T. magnificoides. 

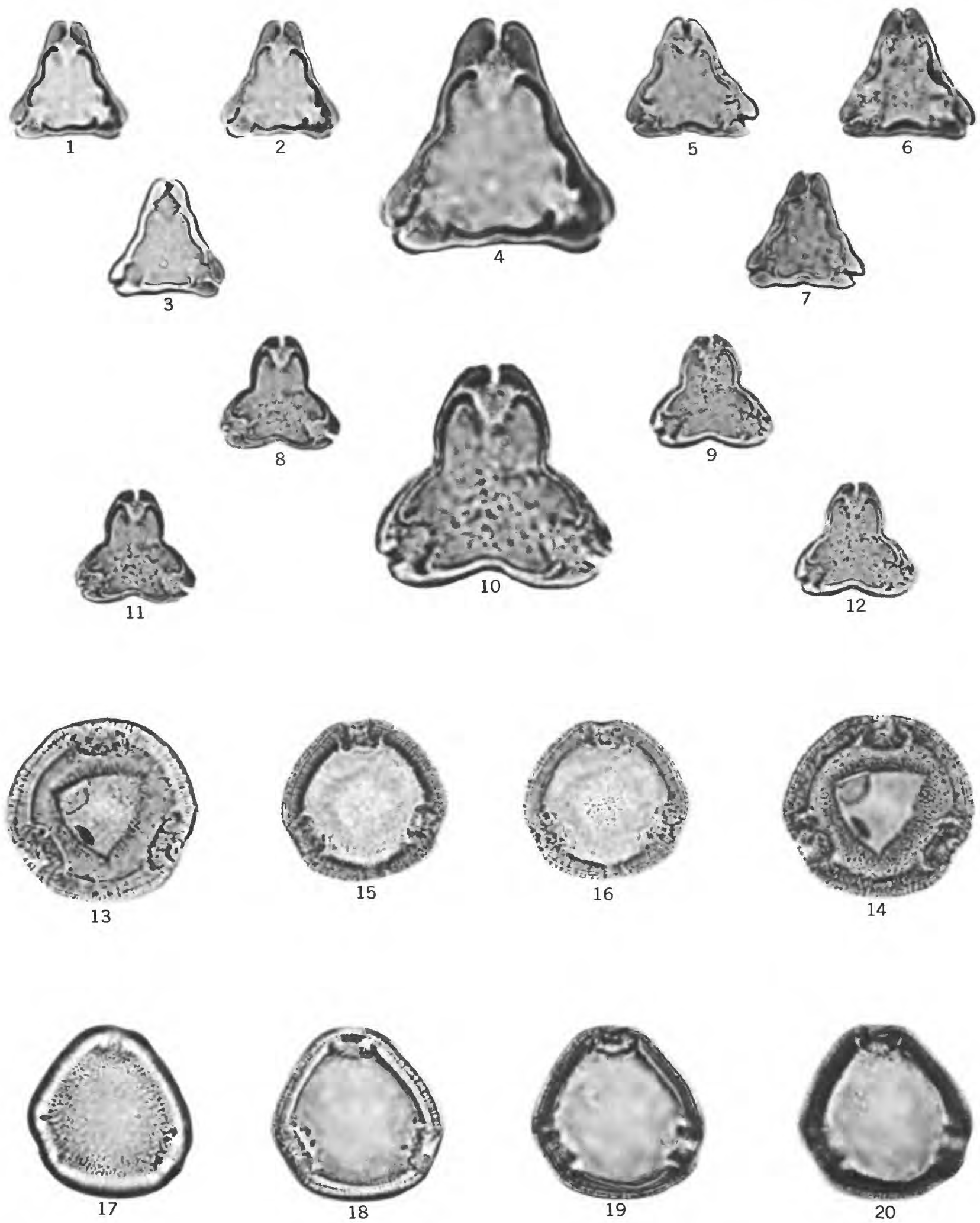


\section{PLATE 15}

[Magnification $\times 1,000$ unless otherwise indicated]

FiguRES 1-8. Thomsonipollis magnificoides

1-2. Sample D1854, slide 3, preparation 2, coordinates $81.5 \times 19.5$, diameter $31 \mu$.

3-4. Sample D1849, slide 1, coordinates $114.7 \times 14.1$, diameter $28 \mu$.

5-6. Sample D1849, slide 3, coordinates $105.8 \times 18.0$, diameter $31 \mu$.

7-8. Sample D1851, slide 3, coordinates $104.8 \times 6.7$, diameter $29 \mu$.

9-20. Thomsonipollis aff. T. magnificoides

9-12. Sample D3548-A, slide 2, coordinates $77.6 \times 17.8$, diameter $21 \mu$.

13-14. Sample D3548-A, slide 2, coordinates $104.5 \times 17.3$, diameter $23 \mu$.

15-16. Sample D3548-A, slide 1, coordinates $88.7 \times 19.1$, diameter $27 \mu$.

17-20. Sample D3548-A, slide 2, coordinates $75.1 \times 17.5$, diameter $23 \mu$. 

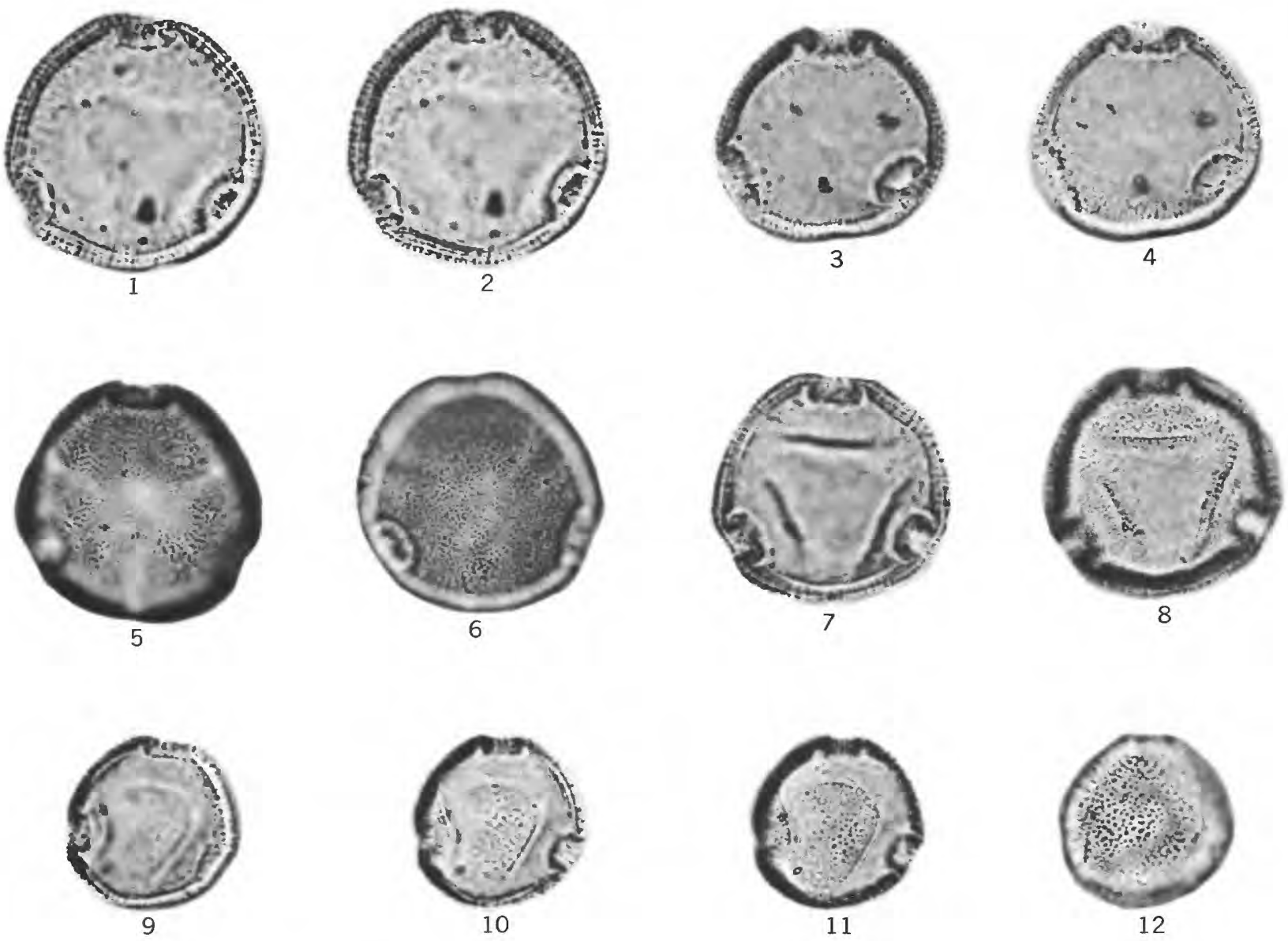

12
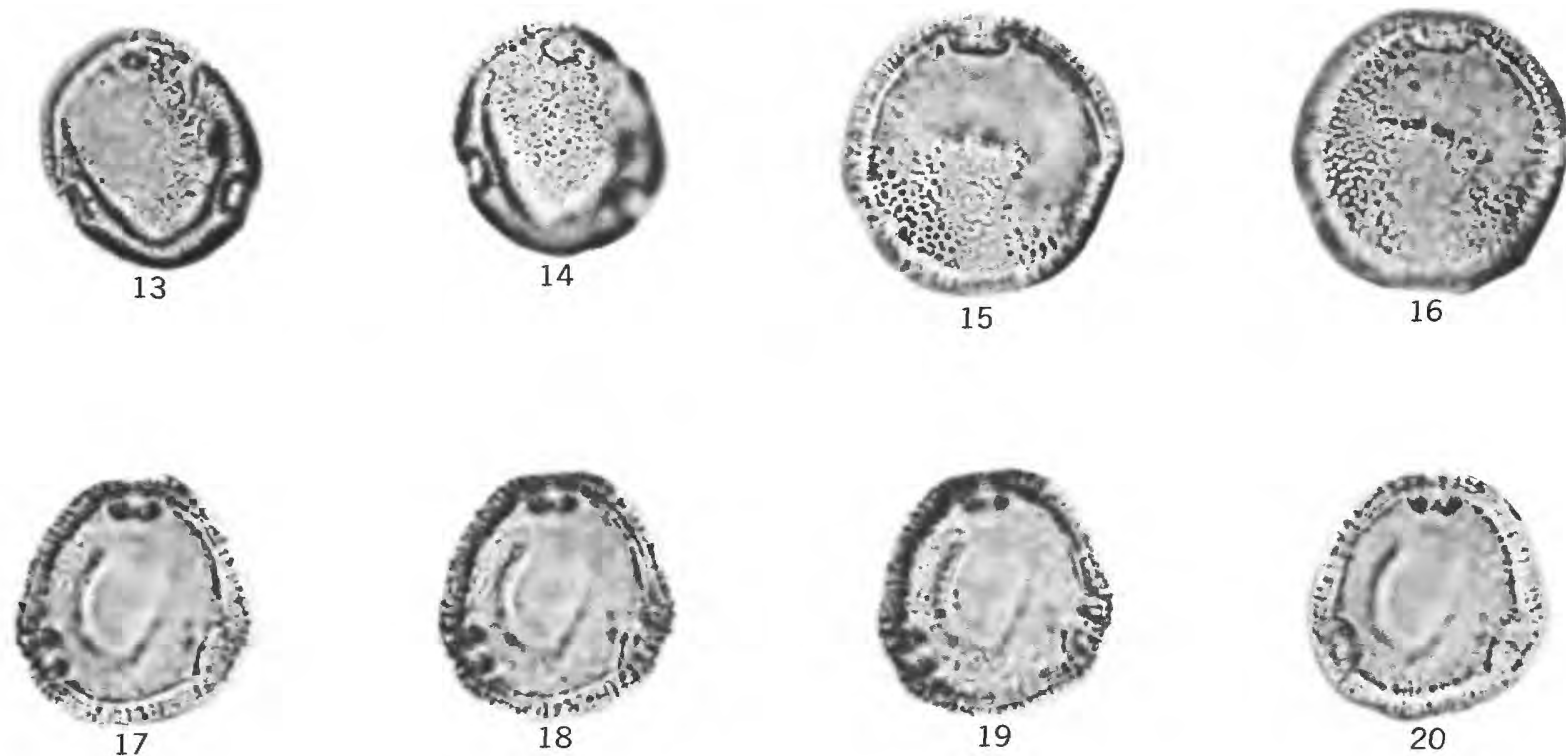


\section{PLATE 16}

[Magnification $\times 1,000$ unless otherwise indicated]

Figures 1-12. Thomsonipollis expolitus, n. sp.

1-4. Holotype, sample D3410-C, slide 4, coordinates $74.5 \times 11.5$, diameter $18 \mu$.

4. Holotype $\times 2,000$

5-7. Sample D3410-C, slide 2, coordinates $107.4 \times 21.0$, diameter $18 \mu$.

8-10. Paratype, sample D3410-C, slide 1, coordinates $104.6 \times 21.4$, diameter $20 \mu$.

10. Paratype $\times 2,000$,

11-12. Sample D3410-C, slide 4, coordinates $74.5 \times 4.5$, diameter $20 \mu$.

13-22. Trudopollis variabilis, $\mathrm{n} . \mathrm{sp}$.

13-15. Holotype, sample D3412, slide 2, coordinates $109.7 \times 14.1$, diameter $26 \mu$.

15. Holotype $\times 2,000$

16-17. Sample D3412, slide 4, coordinates $107.8 \times 11.6$, diameter $22 \mu$.

18-19. Paratype, sample D3412, slide 2, coordinates $99.5 \times 14.8$, diameter $24.5 \mu$.

20-22. Sample D3260, slide 6, coordinates $113.9 \times 6.1$, diameter $28 \mu$. 

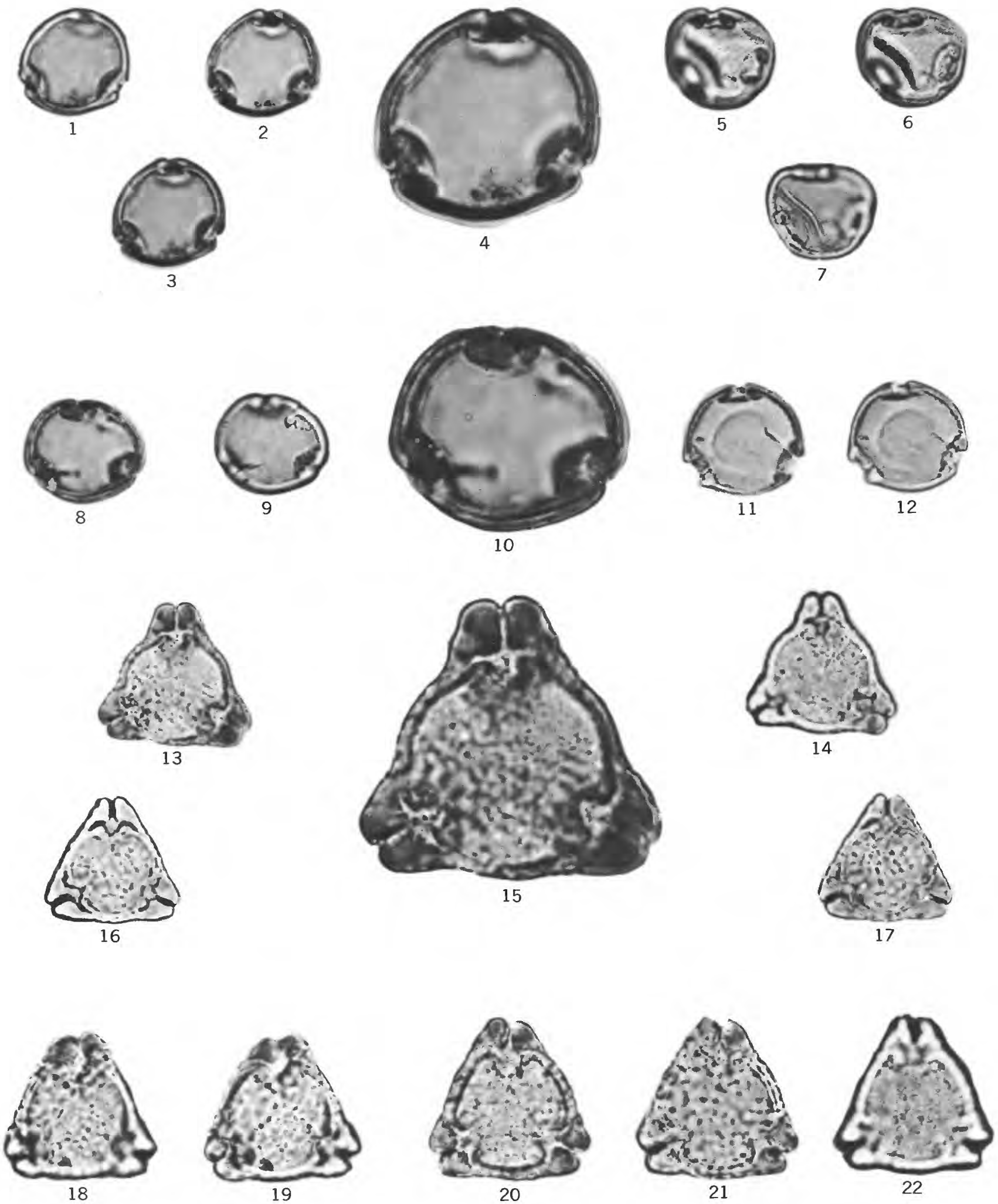


\section{PLATE 17}

[Magnification $\times 1,000$ unless otherwise indicated]

FiguRES 1-9. Trudopollis plenus, n. sp.

1-5. Holotype, sample D 3138 , slide 4 , coordinates $113.6 \times 10.0$, diameter $29 \mu$.

3. Holotype $\times 2,000$. Interloculum shows particularly well.

6-7. Paratype, sample D3138, slide 1, coordinates $91.3 \times 16.7$, diameter $29 \mu$. Faint arci present.

8-9. Sample D3138, slide 3, coordinates $111.8 \times 7.1$, diameter $30 \mu$. Annuli on this specimen larger and slightly protruding.

10-12. Trudopollis sp. A

Sample D3412, slide 1, coordinates $111.5 \times 5.7$, diameter $23 \mu$.

13-14. Trudopollis sp. B

Sample D1849, slide 2, coordinates $89.3 \times 21.5$, diameter $26 \mu$.

15-17. Trudopollis sp. C

Sample D1846, slide 2, coordinates $106.5 \times 7.9$, diameter $31 \mu$.

18-20. Trudopollis cf. T. artifex Wey. and Krg., 1953

Sample D3413, slide 3, coordinates $105.6 \times 6.6$, diameter $28 \mu$. 

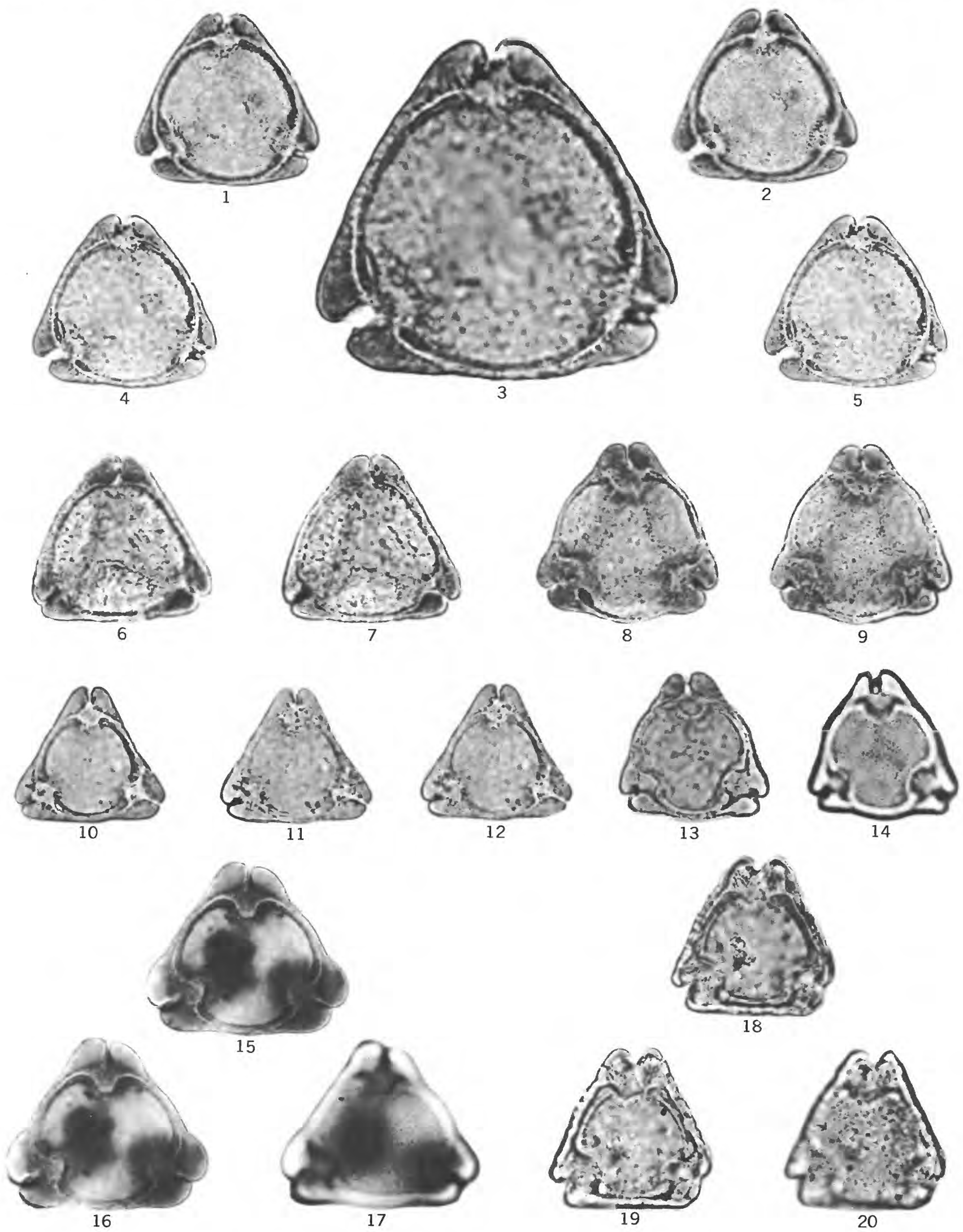

TRUDOPOLLIS PLENUS, T. CF. T. ARTIFEX, AND T. SP. A, B, AND C 


\section{PLATE 18}

[Magnification $\times 1,000$ unless otherwise indicated]

Figures 1-9. Vacuopollis munitus, n. sp.

1-3. Holotype, sample D3416, slide 1, coordinates $74.1 \times 11.8$, diameter $28 \mu$.

3. Holotype $\times 2,000$.

4-5. Paratype, sample D3416, slide 1, coordinates $82.7 \times 18.7$, diameter $26 \mu$.

6-7. Sample D3416, slide 2, coordinates $82.3 \times 5.3$, diameter $26 \mu$.

8-9. Sample D1967-B, slide 1, coordinates $97.8 \times 6.7$, diameter $26 \mu$. This specimen displays a somewhat thicker ektexine.

10-20. Osculapollis aequalis, n. gen., n. sp.

10-14. Holotype, sample D3412, slide 4, coordinates $102.6 \times 3.2$, diameter $23 \mu$.

12. Holotype $\times 2,000$.

15-16. Paratype, sample D3412, slide 3, coordinates $98.5 \times 2.5$, diameter $21 \mu$.

17-18. Sample D3260, slide 5, coordinates $108.8 \times 3.5$, diameter $21.5 \mu$.

19-20. Sample D3412, slide 3, coordinates $100.9 \times 21.7$, diameter $25 \mu$.

21-27. Osculapollis perspectus, n. sp.

21-23. Holotype, sample D3412, slide 3, coordinates $104.1 \times 16.3$, diameter $29 \mu$.

21. Holotype $\times 2,000$.

24-25. Paratype, sample D3412, slide 3, coordinates $105.7 \times 13.7$, diameter $28 \mu$.

26-27. Sample D3412, slide 3, coordinates $95.0 \times 12.9$, diameter $23 \mu$.

28-31. Osculapollis sp. A

28-29. Sample D1862, slide 3, preparation 2, coordinates $97.0 \times 10.0$, diameter $34 \mu$.

30-31. Sample D1862, slide 3, preparation 2, coordinates $93.4 \times 17.3$, diameter $29 \mu$. 

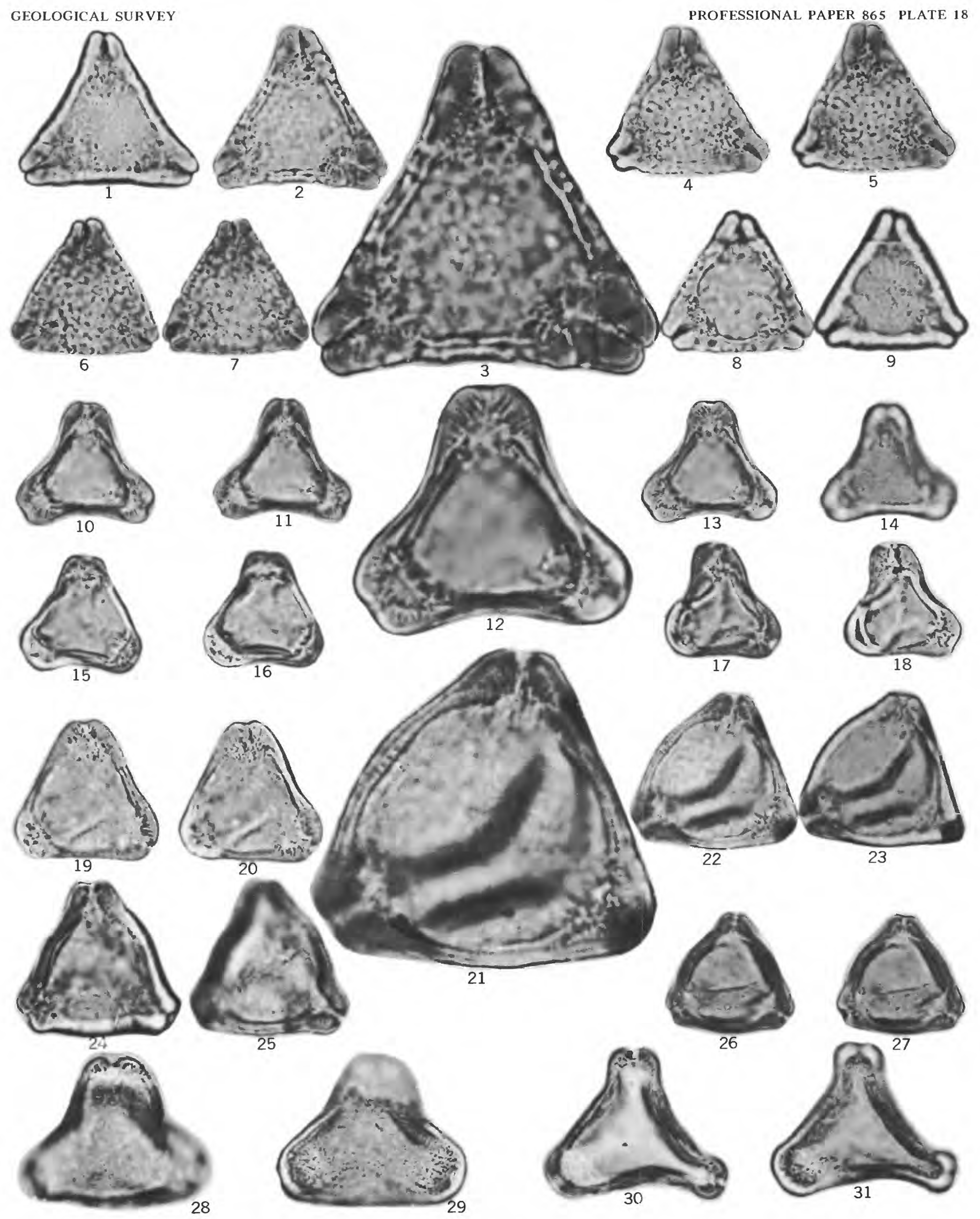

VACUOPOLLIS MUNITUS, OSCULAPOLLIS AEQUALIS, O. PERSPECTUS, AND O. SP. A 


\section{PLATE 19}

[Magnification $\times 1,000$ unless otherwise indicated]

Figures 1-10. Praecursipollis plebius, n. gen. n. sp.

1-3. Holotype, sample D3265, slide 3, coordinates $87.0 \times 5.5$, diameter $16 \mu$.

3. Holotype $\times 2,000$.

4-5. Sample D3265, slide 1, coordinates $102.3 \times 5.4$, diameter $19 \mu$.

6-8. Paratype, sample D3265, slide 4, coordinates $78.4 \times 7.1$, diameter $20 \mu$.

8. Paratype $\times 2,000$.

9-10. Sample D3265, slide 1, coordinates $114.4 \times 18.1$, diameter $19.5 \mu$.

11-28. Pseudatlantopollis simulatus, n. gen., n. sp.

11-13. Holotype, sample D1967-B, slide 10, coordinates $100.0 \times 18.9$, diameter $23 \mu$.

13. Holotype $\times 2,000$.

14-15. Sample D1967-B, slide 8, coordinates $86.6 \times 10.0$, diameter $26 \mu$.

16-17. Sample D1967-A, preparation 2, slide 6, coordinates $106.2 \times 7.2$, diameter $21 \mu$.

18-19. Sample D1967-B, slide 5, coordinates $88.4 \times 4.4$, diameter $23 \mu$.

20-23. Paratype, sample D1967-B, slide 9, coordinates $111.9 \times 18.9$, diameter $25 \mu$. The nature of the reticulum shows well on this specimen.

24-28. Sample D3260, slide 8 , coordinates $112.8 \times 3.4$, diameter $21 \mu$.

26. Same $\times 2,000$. 


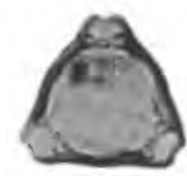

1
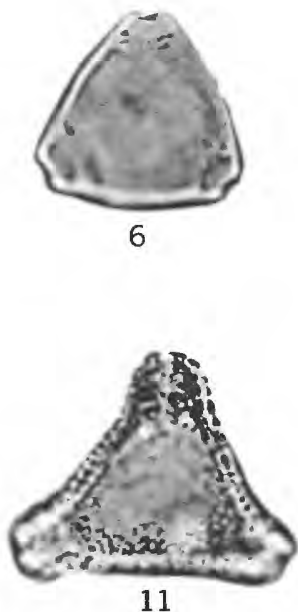

11

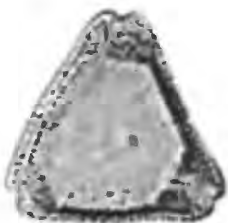

ic

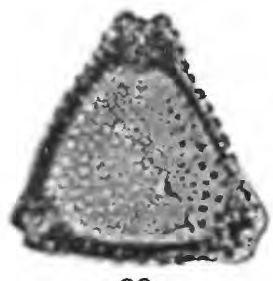

20
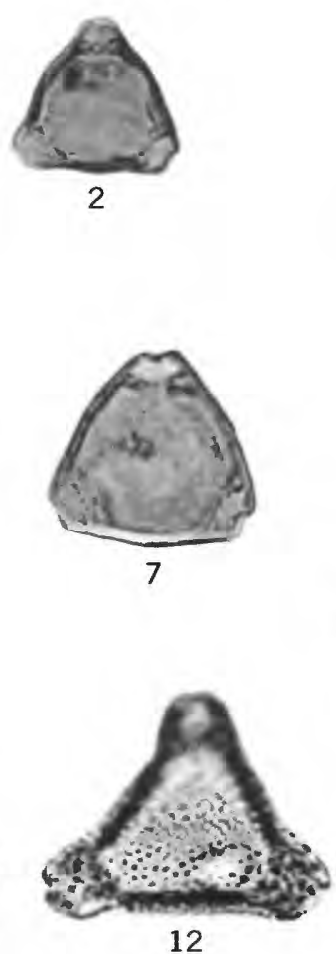

12

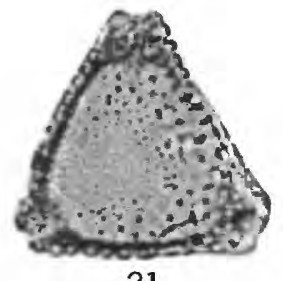

21

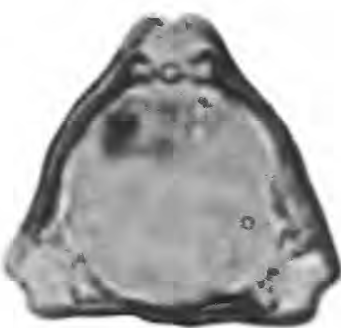

3
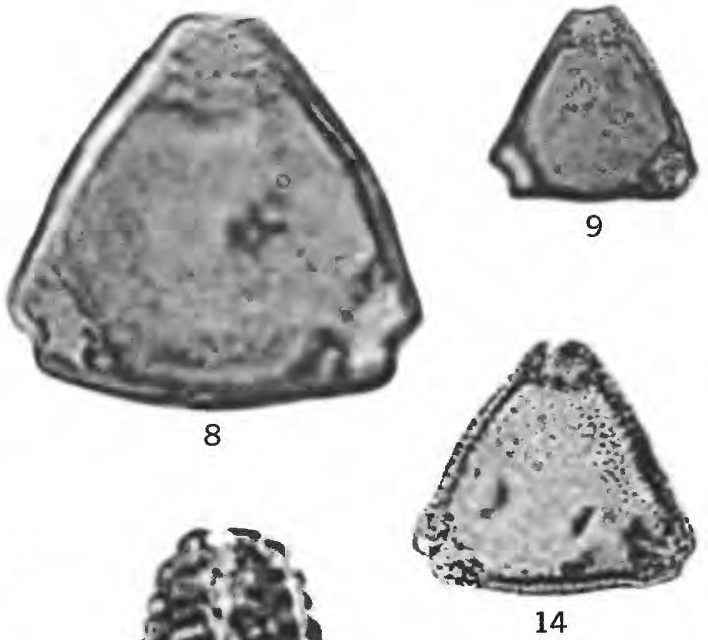
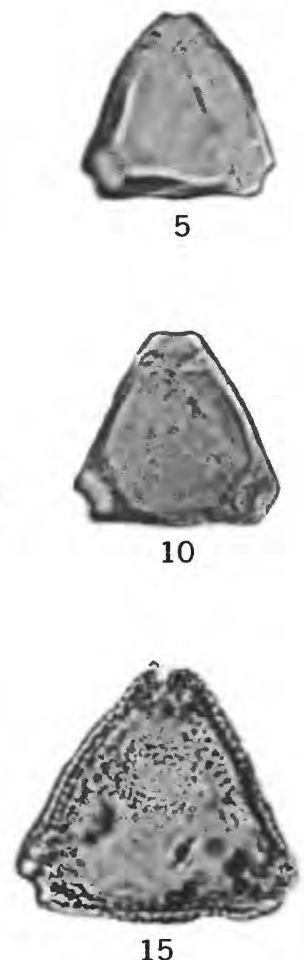

5
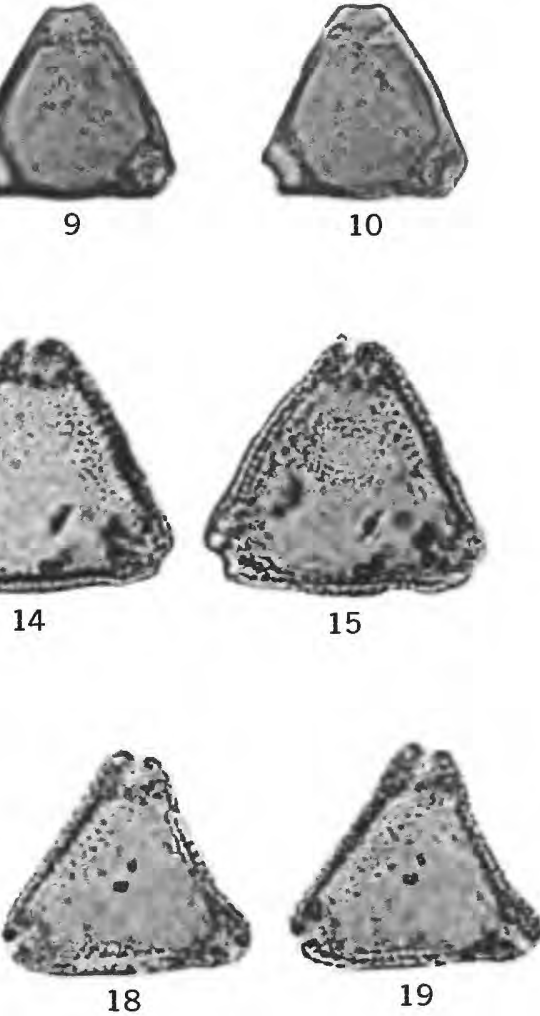

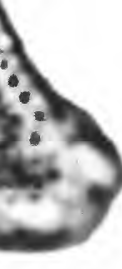

17

13

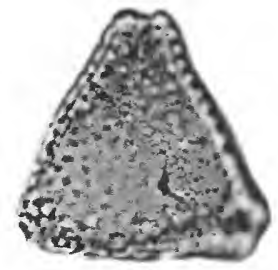

22

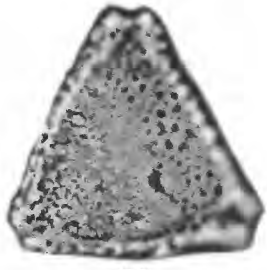

23

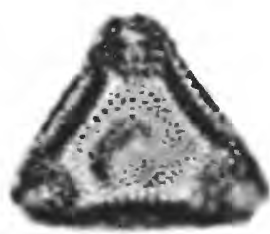

24

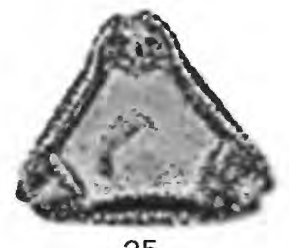

25

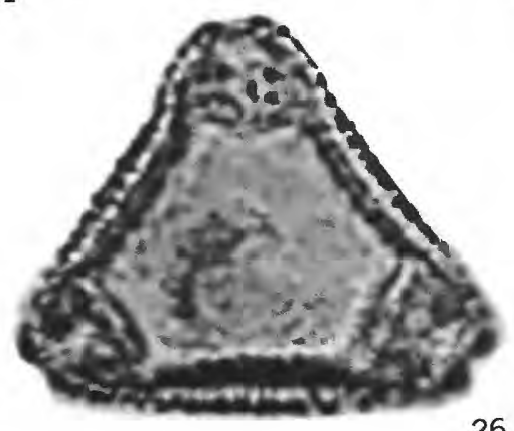

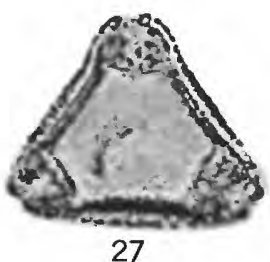

26

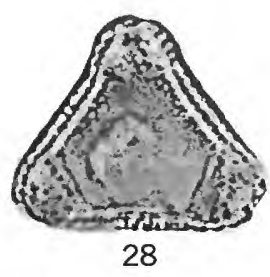

PRAECURSIPOLLIS PLEBIUS AND PSEUDATLANTOPOLLIS SIMULATUS 


\section{PLATE 20}

[Magnification $\times 1,000$ unless otherwise indicated]

FiguRes 1-11. Endoinfundibulapollis distinctus, n. gen., n. sp.

1-5. Holotype, sample D4268-B, slide 1, coordinates $78.5 \times 21.9$, diameter $20 \mu$.

3. Holotype $\times 2,000$

6-7. Paratype, sample D4268-B, slide 2, coordinates $79.2 \times 15.1$, diameter $21 \mu$.

8-9. Sample D3412, slide 4, coordinates $87.7 \times 18$, diameter $20 \mu$.

10-11. Sample D4268-A, slide 1, coordinates $103.0 \times 1.6$, diameter $25 \mu$. 12-14. New Genus A.

12-13. Sample D3265, slide 3, coordinates $81.9 \times 2.1$, diameter $31 \mu$.

14. Same $\times 2,000$.

15-17. New Genus B.

15-16. Sample D3412, slide 1, coordinates $90.9 \times 13.6$, diameter $18.5 \mu$.

17. Same $\times 2,000$

18-20. New Genus C.

18-19. Sample D3410-C, slide 2, coordinates $102.3 \times 19.3$, diameter $28 \mu$. 20. Same $\times 2,000$.

21-23. New Genus D.

21-22. Sample D3410-B, slide 2, coordinates $101.1 \times 19.0$, diameter $44 \mu$. 23 . Same $\times 2,000$, one aperture only. 
GEOLOGICAL SURVEY
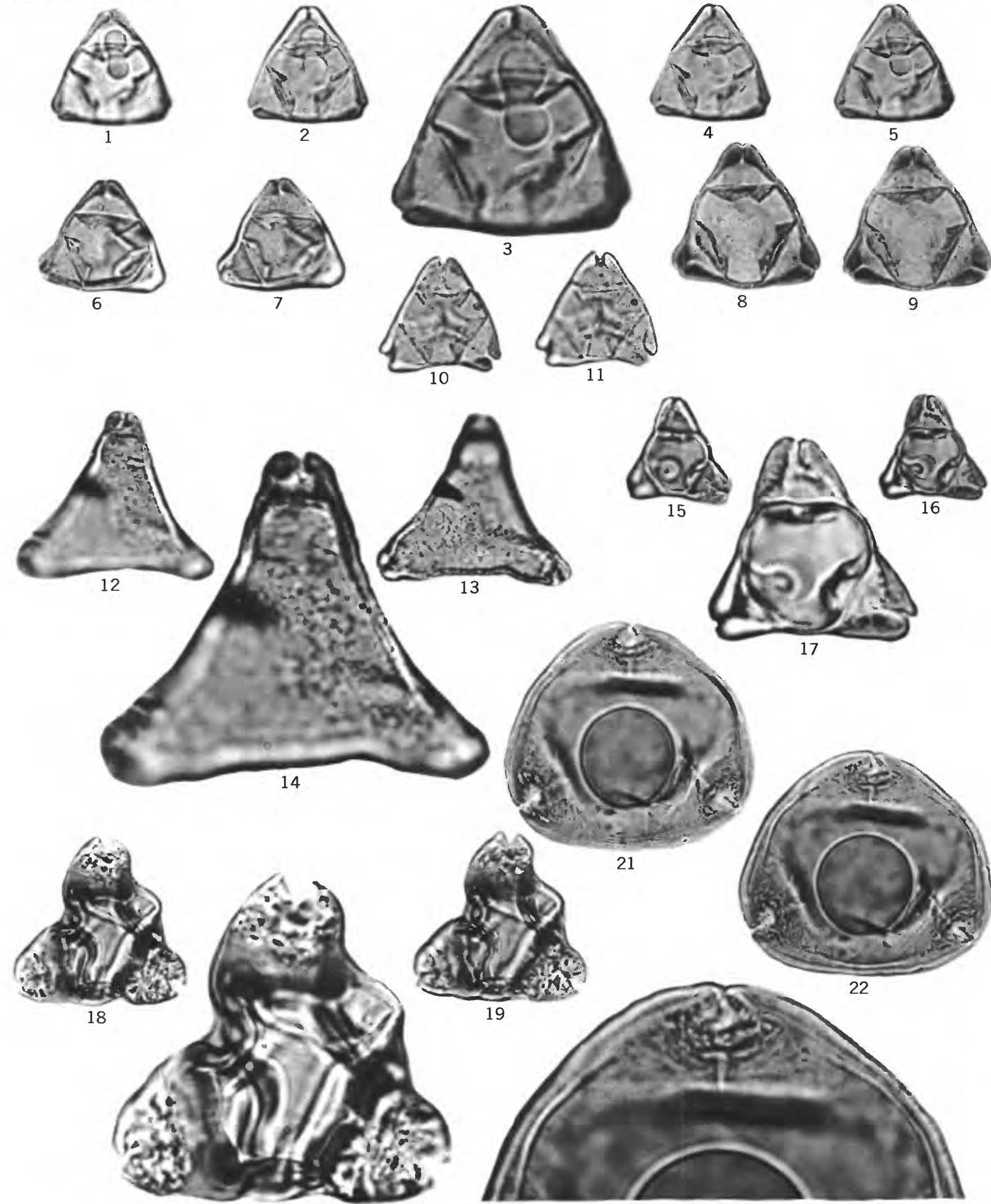

20

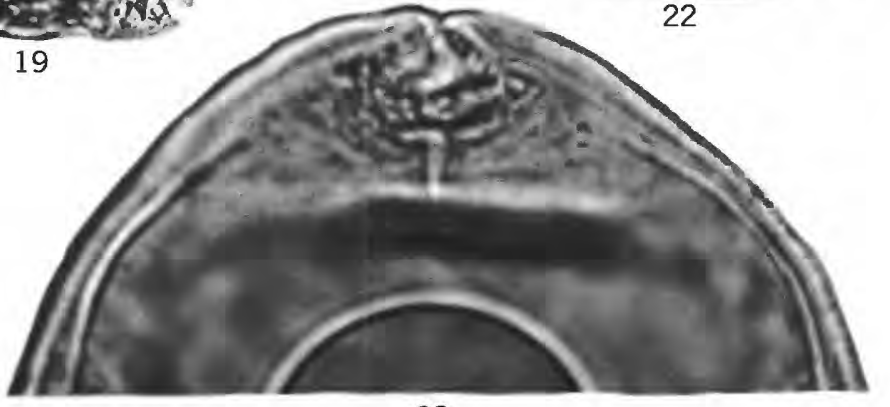

23

ENDOINFUNDIBULAPOLLIS DISTINCTUS AND NEW GENERA A, B, C, AND D 